\title{
Vocational training programs and youth labor market outcomes: Evidence from Nepal ${ }^{\text {is }}$
}

\author{
Shubha Chakravarty ${ }^{\mathrm{a}}$, Mattias Lundberg ${ }^{\mathrm{a}}$, Plamen Nikolov ${ }^{\mathrm{b}, \mathrm{c}, \text {, }}$, Juliane Zenker ${ }^{\mathrm{d}}$ \\ a The World Bank, USA \\ b State University of New York (Binghamton), USA \\ ${ }^{\mathrm{c}}$ Harvard Institute for Quantitative Social Science, USA \\ ${ }^{\mathrm{d}}$ University of Gottingen, Germany
}

\section{A B S T R A C T}

Lack of skills is arguably one of the most important determinants of high levels of unemployment and poverty. In response, policymakers often initiate vocational training programs in effort to enhance skill formation among the youth. Using a regression-discontinuity design, we examine a large youth training intervention in Nepal. We find, twelve months after the start of the training program, that the intervention generated an increase in non-farm employment of 10 percentage points (ITT estimates) and up to 31 percentage points for program compliers (LATE estimates). We also detect sizeable gains in monthly earnings. Women who start selfemployment activities inside their homes largely drive these impacts. We argue that low baseline educational levels and non-farm employment levels and Nepal's social and cultural norms towards women drive our large program impacts. Our results suggest that the program enables otherwise underemployed women to earn an income while staying at home - close to household errands and in line with the socio-cultural norms that prevent them from taking up employment outside the house.

\section{Introduction}

In much of the developing world, unemployment among the youth is extremely high: youths (ages 16-24) comprise 40 percent of the world's unemployed while accounting for only 17 percent of the world's population (United Nations, 2012; ILOSTAT, 2017). High unemployment is not only related to high poverty but also has a strong influence on other important social outcomes: it impacts crime rates (Blattman and Annan, 2016; Fella and Gallipoli, 2014), depression prevalence (Frese and Mohr, 1987), substance abuse rates (Linn et al., 1985), and rates of social exclusion (Goldsmith et al., 1997). Moreover, the low labor force participation of women is particularly pronounced in many regions of the world, resulting in female-specific consequences of unemployment and underemployment, such as low decision-making power in the household and domestic abuse (Majlesi, 2016; Lenze and Klasen, 2016). Therefore, targeting youth unemployment with effective interventions, specifically taking female needs into account, is one of the highest priorities for low-income countries (World Bank, 2013). Although there are numerous determinants for high levels of unemployment and poverty, lack of skills is arguably one of the most important (Heckman et al., 2004; Malamud and Pop-Eleches, 2010). One common policy response in an effort to enhance skill formation among the youth is vocational training programs. To date, more than 700 youth employment programs from 100 countries have been implemented, and more than 80 percent of them

\footnotetext{
We thank the editor and two anonymous referees for comments that significantly improved the paper. Data collection for this paper has been supported through the Swiss Development Corporation (SDC), the UK's Department for International Development (DFID), The World Bank's Multi-donor Trust Fund for Adolescent Girls. We thank Siroco Messerli and Bal Ram Paudel for facilitating all logistical aspects of this study. Headed by Madhup Dhungana, New Era Limited provided exceptional support with survey design, survey implementation and data management. At the World Bank, Jasmine Rajbhandary, Venkatesh Sundararaman, and Bhuvan Bhatnagar led the AGEI project. Amita Kulkarni, Uttam Sharma and Jayakrishna Upadhaya coordinated survey activities. Matthew Bonci, Ali Ahmed, Dayne Feehan, Jake Tuckman, Marine Gassier, Pinar Gunes, and Jennifer Heintz provided outstanding research assistance. Constructive feedback was received from Markus Goldstein, Grant Miller, Eric Edmonds, Susan Wolcott, Chris Hanes, Tristan Zajonc, Jose Luis Montiel Olea, Kristian Rydqvist, Barry Jones, Leonard Goff, Solomon Polachek, Sarah Haddock, Niklas Buehren, Joao Montalvao, Jessica Leino, Brooks Evans, and seminar participants at the World Bank (in its Washington, DC and Nepal offices) and the Economics Department at The State University of New York (at Binghamton). Plamen Nikolov gratefully acknowledges research support by The Harvard Institute for Quantitative Social Science, the Economics Department at the State University of New York (Binghamton), the Research Foundation for SUNY at Binghamton and the EU Commission Marie Curie Micro One World Research Grant. Juliane Zenker acknowledges funding from the Growth and Economic Opportunities for Women (GrOW) initiative. All remaining errors are our own.

* Corresponding author. Contact information for the lead corresponding author: Department of Economics, State University of New York (at Binghamton), 4400 Vestal Parkway East, Library Tower 1012, Binghamton, NY 13902, USA.

E-mail address: pnikolov@post.harvard.edu (P. Nikolov).
} 
offer skills training. ${ }^{1}$

In this paper, we examine one of the largest youth training interventions in Nepal, which serves almost 15,000 poor and disadvantaged young men and women annually by subsidizing skills training and employment placement services. Despite the rapid expansion of skillenhancement programs across the world, this study is among the few to rigorously evaluate such a program in a low-income country. Youth employment rates (other than in subsistence agriculture and informal activities) are exceptionally low in Nepal. In particular, women face difficulties entering the non-farm sector or finding paid employment. In combination with a comprehensive advertisement strategy the training program was created to specifically target young Nepali women.

We examine the program's labor market outcomes based on quasiexperimental techniques. We use a large panel data set of three consecutive cohorts of applicants to the program. Program eligibility was based on individual scores determined by a standardized application procedure and a course-based threshold score. Therefore, we exploit the individualassignment scores to implement a regression discontinuity design. Because we find some evidence that the actual individual assigned score was manipulated in practice, we instead use application-form data to reconstruct the underlying score components and generate our own individual-based score. We then use the reconstructed forcing variable as an instrument for training to estimate the program impacts on compliers (LATE estimates) and as a treatment variable to estimate the programs intent-to-treat (ITT) effects.

We report three major findings. First, approximately twelve months after the start of the training program, the intervention generated an increase in non-farm employment of at least 10 percentage points (based on ITT estimates) and up to 31 percentage points for compliers (based on LATE estimates), both of which are heavily driven by women starting selfemployment activities inside (but not outside) their homes. The program also generated an average monthly earnings gain of at least $659 \mathrm{NRs}(\approx 9$ USD) (based on ITT estimates) and up to 2113 NRs ( $\approx 28$ USD) (based on LATE estimates) for women. Second, in contrast to women, men do not significantly gain from the program along the extensive margin of nonfarm employment in the short run but do show an increase in earnings conditional on any employment of at least 698 NRs, which suggests that they use the program to upgrade their skills. Third, using a small subsample of the initial study population, we find suggestive evidence that 24 months after the start of the program, men have gained along the extensive margin with an increased non-farm (self)-employment rate of at least 19 percentage points, while female medium-term employment and earnings effects stay in a similar range compared to the short-term effects but, possibly due to the lower statistical power, turn insignificant. ${ }^{2}$

Our program impacts stand in stark contrast to the vocational training literature from middle-income countries as these studies generally find small or no effects (McKenzie, 2017). We highlight three explanations of this discrepancy and how they relate to the low-income country context of our study. First, differences in baseline educational attainment suggest that the magnitude of program effects might be very different in low-income countries than those found in middle-income countries. ${ }^{3}$ High poverty rates often go hand-in-hand with low educational levels and, to the best of our knowledge, the baseline educational levels in our

\footnotetext{
${ }^{1}$ See Youth Employment Inventory (http://www.youth-employmentinventory.org/).

2 The increase in effect sizes from the short-to medium-term is in line with results of other studies: Lechner et al. (2011) find average treatment effects on the treated in the form of increased employment rates of 10-20 percentage points in West Germany. Also see Kluve (2010), Card et al. (2010), and Ibarraran et al. (2015) who find evidence of larger medium-term effects.

${ }^{3}$ Betcherman et al. (2007) review findings from vocational programs around the world. The authors posit that programs from middle-income countries are generally more effective than programs from high-income countries, thereby suggesting that program effects may be even larger for vocational training in low-income countries.
}

study sample are the lowest among the existing experimental and quasi-experimental literature. ${ }^{4}$ Low baseline human capital implies a relatively steeper increase in output (and earnings). This relationship between low human capital and large marginal increases in earnings may be further pronounced if gender inequality in educational attainment is high (see, e.g., Knowles et al., 2002; Klasen, 2002).

Second, the measurement of outcome categories can also account for differences between results in middle-income and low-income countries. Low-income countries without institutionalized unemployment insurance are often characterized by a large agricultural and informal sector. The majority of individuals are involved in either subsistence agriculture or informal small-scale businesses as formal employment activities are unavailable (Nayar, 2011). Therefore, unemployment, as it is known in high-income countries, is relatively rare, whereas underemployment is very widespread. Comparing effect sizes between low-income and middle- or high-income countries is further complicated by the fact that the program impacts found within the existing literature in middle-income countries is gauged by any employment or formal versus non-formal employment. ${ }^{5}$ However, both of these criteria are generally not useful in analyzing low-income country samples. ${ }^{6}$ Vocational training in a low-income country is unlikely to yield large employment effects on the extensive margin or on formal employment rates, but can generate large impacts on the intensive margin (hours worked) and on changes in sectorial composition of employment (farm versus informal non-farm employment), which is indeed the case in our study. Our estimated ITT impacts on the probability of any employment (4 percent, insignificant) or wage-employment (3 percent, insignificant) are in fact in line or smaller than the coefficients on wage-employment found in middle-income countries: for example, Attanasio et al. (2011), Card et al. (2011), and Reis (2015) find coefficients that range between 0 and 8 percent. $^{7}$ In contrast, our large effects on the probability of self-employment seem unique to the low-income country context. The few studies from middle-income countries that measure entrepreneurial activities usually find no impact on the probability of self-employment or on self-employment earnings (e.g., Attanasio et al., 2011; Maitra and Mani, 2017).

Third, the fact that the impacts we detect operate mainly through female self-employment inside but not outside the house points to an

\footnotetext{
${ }^{4}$ Based on the program eligibility criteria, very few of the participants had completed higher than a 10th grade education (approximately 12 percent) and a total of 38 percent of individuals in our sample had only primary education or no education. This is dissimilar to other studies from middle- and low-income countries. For instance, Card et al. (2011) report an average of about nine years of schooling at baseline. Alzua et al. (2016) report that only 11 percent of the sample had primary education or lower, while 57 percent of the sample had completed secondary schooling or more. Hirshleifer et al. (2016) report, on average, eleven years of schooling at baseline. Maitra and Mani (2017) report that 45 percent of their sample had completed secondary education at baseline. Adoho et al. (2014) report 46 percent of their sample had attained an education level of 10 th grade or above.

${ }^{5}$ Formal employment is often defined as paid employment that is based on a formal contract and possibly comes with social security benefits like health care, pension, and/or injury compensation, etc. (see e.g. Attanasio et al., 2011).

${ }^{6}$ In our study, individuals employed in the formal sector make up only 1.5 percent of our sample at baseline and 2.5 at follow-up. In Adoho et al. (2014), conducted in Liberia, only five to six percent of the sample is wage-employed at baseline, while formal employment is virtually non-existent. In contrast to these findings, Attanasio et al. (2011) report that in their sample, 7 and 12 percent of women and men at baseline are active in the formal sector, respectively; at the follow-up stage, these numbers are 23 and 38 percent for women and men, respectively. Hirshleifer et al. (2016) detect a share of 30-43 percent formally employed participants in the control group.

7 Overall, these studies provide skepticism regarding the cost-effectiveness of training programs (Almeida et al., 2012). In contrast, the Liberia experiment, mentioned above, cost between $\$ 1200$ and $\$ 1650$ per beneficiary; although this is relatively high, the returns to self-employment training are also sufficiently large to recoup this cost within three years (Adoho et al., 2014).
} 
important dimension in how effect channels may differ across countries: social and cultural norms surrounding work. In traditional societies, women may be more confined by gender roles that constrain their involvement in the labor market. Restrictive norms regarding female labor force participation exist in many regions of the world, but they seem to be particularly strong for women in South Asia (World Bank, 2011; Asian Development Bank, 2015; Booth, 2016). ${ }^{8}$ Our results suggest that the program enables otherwise underemployed women to earn an income while staying at home - close to household errands and in line with the socio-cultural norms that prevent them from taking up employment outside the house. Further, certain ethnicities or castes may face obstacles in utilizing their labor market potential as a result of discrimination by employers or lower access to education (Banerjee and Knight, 1985; Mainali et al., 2017). If a vocational training program manages to unlock this latent potential by taking the unique needs of particularly disadvantaged populations into account-as has been done in the program studied here-it might unleash large employment and earnings potential, whereas, in the opposite case, a similar program might prove less effective (e.g., Cho et al., 2016).

Our paper makes three important contributions to the existing literature on vocational programs in developing countries. First, our paper provides evidence that large program impacts of vocational training programs - particularly in the low-income context - are possible, despite most of the existing evidence from middle-income countries suggesting otherwise. ${ }^{9,10}$ Based on the experience of middle-income countries, only Maitra and Mani (2017), Reis (2015) and Alzua et al. (2016) find positive impacts on the probability of any employment and any earnings in India, Brazil, and Argentina, respectively. On the other hand, Honorati (2015), Card et al. (2010), Attanasio et al. (2011, 2015), Ibarraran et al. (2015), Hirshleifer et al. (2016), Acevedo et al. (2017), Diaz and Rosas (2016), and Galasso et al. (2004) find either mixed, muted, or no impacts at all from vocational programs on various labor market outcomes. ${ }^{11}$ That large effects may be particularly pronounced in low-income contexts is confirmed by two studies conducted in Liberia and Uganda ${ }^{12}$ : Adoho et al. (2014) randomly assign a similar intervention like the one studied here and detect an increase of 47 percent in non-farm employment and 80 percent in earnings among young Liberian women. Similarly, Bandiera et al. (2017) find positive impacts on income generating activities of 48 percent (which

\footnotetext{
${ }^{8}$ Only one other quasi-experimental study in South Asia examines the impact of training programs on employment and earnings. Maitra and Mani (2017) evaluate a training program in stitching and tailoring offered to young women in New Delhi. They find that program participation increased employment by more than 5 percentage points, self-employment by almost 4 percentage points, and any employment by 6 percentage points. The program increased number of hours worked by approximately $2.5 \mathrm{~h}$. However, the smaller effect sizes are based on ITT estimates, which are based on much lower compliance rates (56 percent) compared to our study (70 percent). Also, initial levels of wage-employment and education are higher in India as Nepalese socio-cultural norms regarding gender roles may be less restrictive in New Delhi compared to rural Nepal where most of our courses take place.

${ }^{9}$ We use the World Bank income classification of countries from http:// databank.worldbank.org/data/download/site-content/CLASS.xls.

${ }^{10}$ Most of the vocational training literature on similar programs in high- or middle-income countries finds low or insignificant effects (Card et al., 2010; Kluve, 2010; Dar and Tzannatos, 1999).

11 Other authors document similarly sized impacts based on related active labor market policies such as wage subsidies (Galasso et al., 2004; Groh et al., 2016; Levinsohn et al., 2014)) or search and matching assistance (Abebe et al., 2016a, 2016b; Franklin, 2015; Jensen, 2012; Groh et al., 2015; Dammert et al., 2015; Beam, 2016; Abel et al., 2016; Bassi and Nansamba, 2017) or education-related interventions documented by Nikolov and Jimi (2018).

12 Rigorous evidence of one other vocational program based in low-income countries exists: In Malawi, Cho et al. (2016) find no impacts on hours worked and no impacts on other employment outcomes. Yet, the authors explain that an unsatisfactory tailoring of the program to the needs of the target group in combination with large numbers of drop-outs are likely responsible for the low effects.
}

were almost entirely driven by self-employment), but no positive impacts on wage-employment in Uganda. Our second contribution to the existing literature relates to the pattern of different returns to vocational training between women and men. Although Blattman and Ralston (2015) point to a stylized fact that proposes vocational training has higher returns for women, McKenzie (2017) reviews recent vocational training programs in low-income and middle-income countries and, in fact, argues that previous studies, which formally test for equality by gender, can either not reject similar impacts for men and women, or have found significantly higher impacts for men. ${ }^{13}$ In stark contrast, our study does formally test for equality by gender and it unambiguously shows robust evidence that vocational training in our context yields higher returns for women. We highlight that our results are likely driven by the socio-cultural norms in Nepal, which shape gender roles that identify women with more restrictive characteristics and capabilities in the labor market compared to other country contexts in the training literature (e.g., Latin America). This exemplifies that generalizing heterogeneous impacts of policies such as the one investigated here should (if at all) be done very cautiously, carefully considering the relevant effect channels. Finally, our study underscores that measuring a wider range of employment outcomes, such as self-employment, may be necessary to comprehensively study the impact of active labor market programs. Even though formal employment per se is not affected by the vocational training in our context, we are able to identify some short run effects on women's self-employment that less comprehensive labor market surveys of previous studies may have missed.

The remainder of the paper is structured as follows. Section 2 provides background information on Nepal's labor market and details Nepal's Employment Fund training program and the intervention design. Section 3 describes the data, sampling strategy and sample characteristics. Section 4 presents the study design, and Section 5 describes the empirical strategy. Section 6 presents the results, and Section 7 provides various robustness checks. Section 8 concludes.

\section{Background}

\subsection{The labor market in Nepal}

Nepal's economy ranks among the world's poorest. In 2010, a quarter of the country's population lived below the national poverty threshold. The Nepalese economy is characterized by lack of formal sector jobs, a large informal sector, and wide-spread underemployment (affecting approximately half of the workers in the younger age groups), all of which contribute to very high poverty rates (ILO, 2004; Central Bureau of Statistics, 2009). ${ }^{14,15}$ Based on the Nepal Labour Force Survey 2008, 74

\footnotetext{
13 To the best of our knowledge, considering the rigorous evidence on vocational training programs, only Alzua et al. (2016) formally test for gender-disaggregated effects and find a difference: the authors document larger impacts for men.

${ }^{14}$ Although no labor survey specifically collects informal sector data, some economic measures point to the size of the informal sector constituting more than two-thirds of the economically active population in Nepal (Suwal and Pant, 2009). One of the reasons for Nepal's bad economy and its underdeveloped formal sector is the political turmoil the country experienced in the last two decades: a peace agreement between the government and the Maoist insurgency, an interim constitution promulgated in 2007, the 2008 declaration of a democratic republic, new and rising ethnic political movements, and a democratically elected Constituent Assembly in 2013.

15 Nepal's 2008 labor force survey (Central Bureau of Statistics, 2009) shows that 21 percent of the individuals working less than $40 \mathrm{~h}$ per week are in fact able to work more and are therefore underemployed. Shortage of employment opportunities has generated a migration flow to urban areas and migration to other countries, especially to the Gulf States (Lokshin and Glinskaya, 2009). Nepal's net migration has registered an outflow of migrants near half a million for the period 2008 to 2012. During the same period, Nepal's net migration rate has exceeded the same number for the overall migration rate of South Asia.
} 
percent of laborers work in the agricultural sector while 64 percent work in subsistence agriculture. Women are particularly underrepresented in non-agricultural employment. Although the Nepal Labour Force Survey 2008 reports a labor force participation of women (80.1 percent) that is similar to that of men (87.5 percent), approximately three quarters of employed women work in subsistence agriculture (compared to 52.9 percent of men), whereas only 26.2 percent are engaged in paid work (compared to 73.9 percent of men). Moreover, monthly earnings of female paid employees are much lower on average (NRs 3402 versus 5721 for men) (Central Bureau of Statistics, 2009).

Low skills and high youth unemployment. The country's labor market outcomes can, to some degree, be attributed to low levels of human capital accumulation. According to the Nepal Labour Force Survey 2008, the total literacy rate for individuals of ages 15 years and above is 55.6 percent (70.7 percent for men and 43.3 for women). Only 22 percent of women and 29 percent of men have more than a primary education, and approximately half of the Nepalese have no formal schooling at all (Central Bureau of Statistics, 2009). These numbers are staggeringly low even in comparison to the human capital indicators of other South Asian countries and the rest of the developing world. For instance, in Latin America, where most of the available experimental evidence on the effectiveness of training programs in developing countries comes from, approximately 75 (50) percent of the population of age 15 (20) or above had completed primary (lower secondary) education in 2004 (UNESCO, 2007). Moreover, lack of vocational skills is predominant among young Nepalese. Around half a million young people join the labor force each year, the vast majority of them being unskilled. Although the market demand for skills is high, access to vocational training is limited, particularly among the poor and disadvantaged groups.

Cultural and Social Norms Regarding Female Employment. A combination of low educational attainment and restrictive norms towards marriage, childbirth, and household duties generate multiple constraints for young women who wish to enter the labor market. These constraints are reflected in the different reasons that young men and women report for not participating in the labor force: although the majority of economically inactive men between ages 15 and 29 report that they are attending school (85.3 percent), only 43.9 percent of women of the same age group report school enrollment as their major reason. Instead, 41.6 percent of economically inactive women between ages 15 and 29 and even 80.1 percent of women between ages 30 and 44 report to be economically inactive because they have to engage in (unpaid) household duties, while virtually none of the men in these age groups state household duties as a reason for being absent in the labor market (Central Bureau of Statistics, 2009).

In addition, being bound to their households and families because of gender roles, women also face three broad gender-based employment barriers, which further complicate their economic well-being: restricted mobility, cultural norms, and societal norms regarding gender expectations for certain occupations. Largely influenced by Hindu philosophy related to men and women's positions in society, Nepal's socio-cultural practices differ by caste and ethnicities. For example, related to the first employment barrier, in southern Nepal (Terai and Madhesh) women are frequently confined to the household and are unable to travel outside of their immediate community for any work. Various proscriptions based on the Madhesi culture restrict females from leaving their homes. The second gender-related barrier relates to cultural norms that prohibit women from interacting with men other than their family members. For example, in conservative parts of the Terai districts, females who are trained as barbers are not employed due to cultural prohibitions against women touching men. The third gender-based labor market barrier relates to women who choose to train and work in traditionally maledominated occupations. In various typically male-dominated occupations - for example, computer and television repair, auto body making and construction work - customers frequently express doubts regarding the quality of skills of women assigned to such repair jobs. As a result of the societal difficulties women face, they remain engaged in unpaid, home-based labor to a large extent. Approximately 80 percent of the unpaid family labor force is female (Central Bureau of Statistics, 2009).

In summary, the low educational levels and the shortage of skill training opportunities suggest that the return to obtaining additional training - especially for women - may be particularly high in Nepal. With that said, training for women may only be successful if the program takes female-specific needs into account so that it can enable them to expand their economic activities while adhering to their social roles and the cultural norms of their communities.

\subsection{The Nepal Employment Fund}

Started in 2008, the Employment Fund (EF) is one of the largest skills training initiatives in Nepal. The program provides vocational training and placement services under a unique governance structure in cooperation with local training providers. The EF program subsidizes short-term market oriented skill training in combination with other services for disadvantaged young women and men. The fund's objective is to place trainees into gainful employment upon training completion. Each year, the EF sponsors about 600-700 training courses. The EF-subsidized courses are announced publicly in local communities with the intent to encourage potential candidates to apply. The applicants are then selected by a standardized procedure based on eligibility criteria. Available seats are restricted due to the limited capacity of training providers. As of 2010, the program operates at scale nationwide and covers 54 districts, providing training for over 65 occupations and has expanded in the consecutive years. Table 1 provides an overview of the total number of training events, trainees, and training providers for the time of our study period (2010-2012).

Program components. Admission to the program offers the trainees a bundle of services, where the core components are technical training (including certification) and job-search-assistance. Training courses in technical skills vary across a wide range of trades (e.g., incense stick rolling, carpentry, tailoring, welding, and masonry) and last from four weeks to three months. Each trainee is encouraged to complete a skills certification test offered by the National Skills Testing Board (NSTB). Upon completion of the classroom-based training, the EF emphasizes job placement services. Once the first training phase is completed, training providers are required to link trainees to trade-specific employers for six months of paid on-the-jobtraining. Providers often use their trade-specific networks of trainers and employers to find suitable internships for their graduates. Through the internship, trainees obtain immediate work experience as they apply their learned skills in the market and, subsequently, strengthen their social capital and contacts with potential employers. In addition to the core components of the program, all females receive $40 \mathrm{~h}$ of life-skills training (started in 2010 and fully implemented in 2011). The 40-h training curriculum covered topics such as negotiation skills, workers' rights, sexual and reproductive health and discrimination response. A subset of trainees also received a short course in basic business skills.

Outcome-based payments. Training providers are rewarded for their services in three installments based on a set of pre-determined outcomes.

Table 1

Total and sampled EF events.

\begin{tabular}{lllll}
\hline & 2010 & 2011 & 2012 & Pooled \\
\hline All EF events & & & & \\
\# Events conducted by EF (all year) & 598 & 645 & 711 & 1954 \\
\# Events conducted by EF (Jan-Apr) & 110 & 142 & 143 & 395 \\
\# Training providers & 21 & 32 & 35 & - \\
\# Trainees & 11750 & 12869 & 14255 & 38874 \\
Sampled EF events & & & & \\
\# Events randomly sampled for baseline & N/A & 182 & 112 & - \\
$\quad$ survey & & & & \\
\# Events included in baseline survey & 65 & 69 & 85 & 219 \\
\# Districts covered & 12 & 28 & 26 & - \\
\# Training providers covered & 18 & 26 & 28 & - \\
\hline
\end{tabular}

Notes: More events were sampled than conducted in Jan-Apr 2011 because some events that were scheduled for Jan-Apr were delayed and did not start on time. 


\begin{tabular}{|c|c|c|c|c|c|c|c|c|c|c|}
\hline & \multicolumn{3}{|c|}{2010} & \multicolumn{3}{|c|}{2011} & \multicolumn{3}{|c|}{2012} & 2013 \\
\hline & Jan-Apr & & & Jan-Apr & & & Jan-Apr & & & Jan-Apr \\
\hline $\begin{array}{l}2010 \\
\text { Cohort }\end{array}$ & $\begin{array}{l}\text { Baseline } \\
\text { Survey } \\
\text { /Start of } \\
\text { Training }\end{array}$ & \begin{tabular}{|c|}
$1^{\text {st }}$ \\
EF \\
Verif.
\end{tabular} & \begin{tabular}{|c|}
$2^{\text {nd }}$ \\
EF \\
Verif.
\end{tabular} & $\begin{array}{l}\text { 1st Follow- } \\
\text { up Survey }\end{array}$ & & & $\begin{array}{c}\text { 2nd } \\
\text { Follow-up } \\
\text { Survey* }\end{array}$ & & & \\
\hline $\begin{array}{l}2011 \\
\text { Cohort }\end{array}$ & & & & $\begin{array}{l}\text { Baseline } \\
\text { Survey } \\
\text { /Start of } \\
\text { Training }\end{array}$ & \begin{tabular}{|c|}
$1^{\text {st }}$ \\
EF \\
Verif.
\end{tabular} & \begin{tabular}{|c|}
$2^{\text {nd }}$ \\
EF \\
Verif.
\end{tabular} & $\begin{array}{l}\text { 1st Follow- } \\
\text { up Survey }\end{array}$ & & & \\
\hline \begin{tabular}{l|}
2012 \\
Cohort
\end{tabular} & & & & & & & $\begin{array}{l}\text { Baseline } \\
\text { Survey } \\
\text { /Start of } \\
\text { Training }\end{array}$ & \begin{tabular}{|c|}
$1^{\text {st }}$ \\
EF \\
Verif.
\end{tabular} & \begin{tabular}{|c|}
$2^{\text {nd }}$ \\
EF \\
Verif.
\end{tabular} & $\begin{array}{l}\text { 1st Follow- } \\
\text { up Survey }\end{array}$ \\
\hline
\end{tabular}

Notes: Baseline interviews were usually conducted a few days or weeks before start of training. Follow-up interviews were conducted approximately 12 and 24 months after baseline interviews, respectively. Training duration lasts from 1 to 3 months. EF verifies employment status and earnings of applicants 3 and 6 months after end of training, i.e., approx. 8 to 6 and 5 to 3 months before the first follow-up survey. *Roughly half of the initial sample of the 2010 cohort was randomly selected for the second follow-up survey.

Fig. 1. Timeline.

A provider qualifies to receive full payment - i.e., the full price of the training and services provided plus a bonus based on whether the trainee belongs to a vulnerable group - by a set contract between the EF and the training provider. The contract stipulates that all accepted trainees must successfully complete their skills training and sit for a skills test given by the Nepal National Skills Testing Board (NSTB). When trainees complete the test, providers obtain their first installment (40 percent of total payment). Upon the exam completion, providers are expected to ensure that graduates remain continuously employed for the next six months and that they earn above 3000 NRs per month ("gainful employment"). The EF verifies three months and six months after training completion whether or not trainees are gainfully employed. If the verification process is successful, the training provider obtains the second and the third installments ( 25 percent and 35 percent of total payment, respectively). ${ }^{16}$ The cost for training and employment services is pre-financed by the providers and is reimbursed to them only when they accomplish the outcomes in their contract. Therefore, training providers bear the risk of losing their investment if they are unsuccessful in training and placing their trainees accordingly.

Targeting disadvantaged groups. Three factors comprise the eligibility criteria for all EF-sponsored training programs: age (from 16 to 35), education (below SLC, ${ }^{17}$ or less than ten years of formal education) and low self-reported economic status. Only applicants who meet all three criteria were viable for being short-listed in the admission procedure. Furthermore, and as mentioned above, providers receive a bonus payment for successfully training and placing candidates who belong to particular disadvantaged groups. ${ }^{18}$ The bonus payment is calculated as a percentage of the full cost of training and services provided and is issued

\footnotetext{
${ }^{16}$ Employment status of a randomly selected sample of graduates is verified by EF field monitors.

17 The School Leaving Certificate (SLC) is obtained after successfully passing examinations after the 10th grade. To be eligible, EF applicants must have not taken, or not passed, their SLC exams. This criterion has been loosened for some trades starting in 2012.

18 Disadvantaged groups are defined by the EF as people belonging to the Dalit community, ex-combatants, internally displaced, widows (only women), disabled, HIV/AIDS infected, and formerly bonded laborers.
}

proportionally together with the three installments described above, as long as the particular requirement for each installment is fulfilled. A provider receives a bonus payment of 40 percent of the base cost of training for a man who is poor and 50 percent for a man who is poor and belongs to a disadvantaged group. A provider further receives a bonus payment of 70 percent of the base cost of training for a woman who is poor and 80 percent for a woman who is poor and belongs to a disadvantaged group. ${ }^{19}$

In 2010, the EF, partnering with the World Bank, made additional efforts to specifically target young women aged 16 to 24 . Training under the Adolescent Girls Employment Initiative (AGEI) proceeded in the same way as it did for other EF trainees, except that certain events had been flagged in advance as likely to attract female trainees. In addition to regular training course advertisement, the $\mathrm{EF}$ sponsored radio and newspaper ads specifically geared towards young women. Many of these ads specifically encouraged women to sign up for traditionally male trades, such as mobile phone repair, electronics, or construction.

\section{Data}

\subsection{Sampling}

We used two primary sources of data. First, we used data from training application forms and the selection procedure of EF-sponsored training that covered three consecutive cohorts of applicants (from 2010 to 2012). Second, we conducted individual (applicant) and household surveys with two rounds of data collection for each cohort. For the 2010 cohort, a second follow-up was conducted on half of the cohort. Fig. 1 shows the survey timeline.

Sampling into this study included a combination of stratified, random, and convenience sampling and was done in two consecutive steps. For each cohort, the first step consisted of a selection of training events, and the second step consisted of selecting individuals according to standardized procedures. The event sampling-frame for this study

\footnotetext{
19 Poverty is defined as less than six months of food sufficiency for farm households or less than 3000 per capita family income, from non-farm based income.
} 


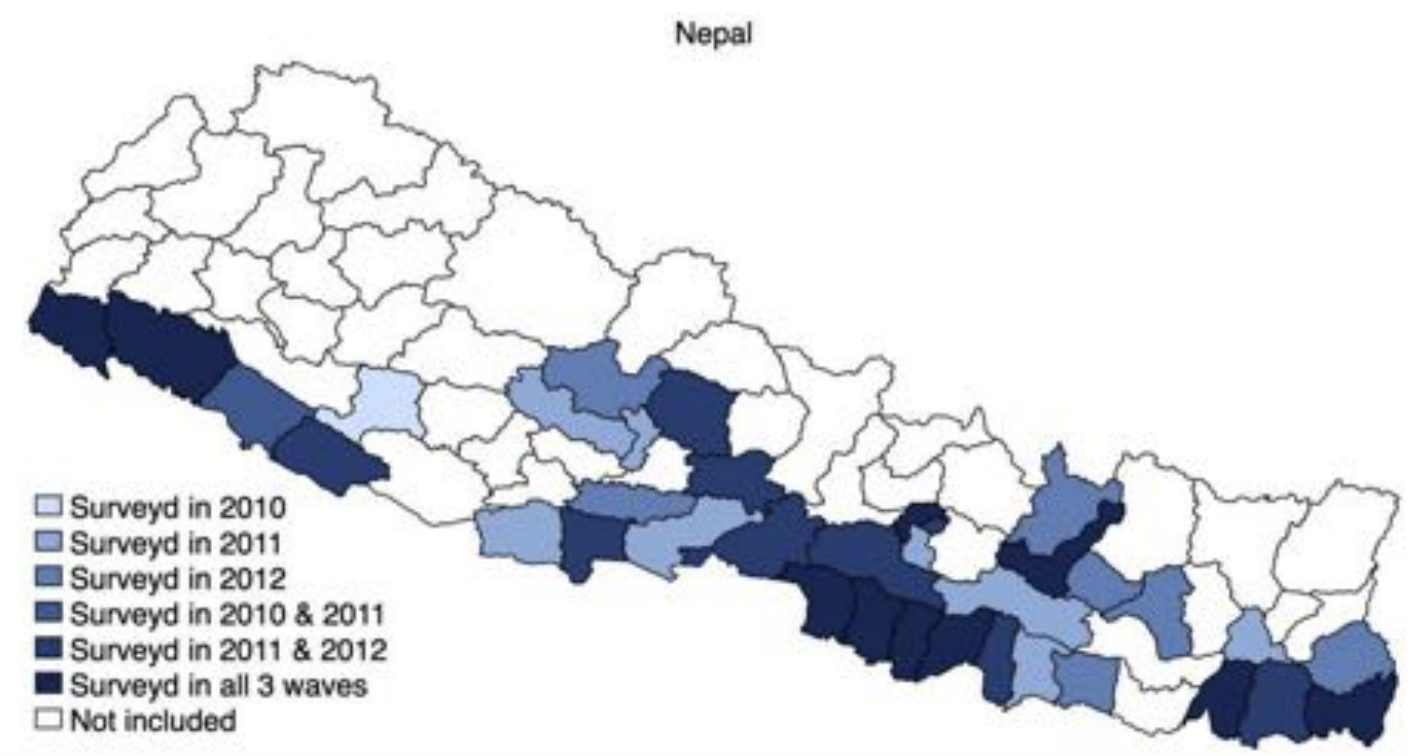

Fig. 2. Districts covered by cohort.

consisted of all training events from the universe of the EF funded trainings that occurred between January and April of each year. Events were grouped into clusters of close-by districts before sampling for survey administrative reasons. We then randomly sampled up to 15 district clusters in each of the three years, respectively. Furthermore, from the list of training events that took place in these district clusters, we randomly selected 20 percent. Because of the focus on young women in this study, events that were likely to include more young women (identified by training providers) were purposely oversampled in 2011 and 2012. In 2010, because a complete event listing was not available in advance, the events were not chosen randomly but by convenience, based on scheduling and accessibility. Table 1 details the resultant sample of events for the three cohorts.

The 2010 sample comprised 65 events across 12 districts. The 2011 sample comprised 182 events, of which 113 events were dropped from the baseline survey, either because the survey team could not reach the event on the day of applicant selection (usually due to weather conditions) or because the event was not "oversubscribed". ${ }^{20}$ The remaining 69 events in 28 districts were included in the 2011 baseline sample. In 2012, 85 out of 112 sampled events covering 26 districts were included in the study sample. Fig. 2 depicts the study areas by survey.

To sample applicants, a survey team visited each sampled training event on the day when applicant selection happened. The sampling of applicants was based on the standardized interview procedure that was used to determine training assignments. During the assignment procedure (which we will describe in more detail below), applicants received scores in five different categories that were added up to form a total score. A ranking sheet was then used to list applicants from the top scorer to the bottom scorer and indicated the threshold (i.e., minimum score) for admission to the course. The individuals we study comprise a subset of the ranked individuals - those who fell in the range of 20 percent below or above the threshold. Immediately following the sampling of applicants but before the results of the selection process were announced, a baseline survey was administered.
Table 2

Survey response rates.

\begin{tabular}{llll}
\hline & Baseline & Follow-up & Follow-up rate \\
\hline 2010 cohort & & & \\
Above Threshold & 1184 & 1047 & $88.4 \%$ \\
Below Threshold & 372 & 330 & $88.7 \%$ \\
Total & 1556 & 1377 & $88.5 \%$ \\
$\mathbf{2 0 1 1}$ cohort & & & \\
Above Threshold & 1237 & 1113 & $90.0 \%$ \\
Below Threshold & 349 & 306 & $87.7 \%$ \\
Total & 1586 & 1419 & $89.4 \%$ \\
2012 cohort & & & \\
Above Threshold & 1044 & 888 & $85.1 \%$ \\
Below Threshold & 491 & 417 & $85.0 \%$ \\
Total & 1535 & 1305 & $88.0 \%$ \\
Pooled cohorts & & & $86.9 \%$ \\
Above Threshold & 3465 & 3049 & $87.7 \%$ \\
Below Threshold & 1212 & 1053 & \\
Total & 4677 & 4101 & \\
\hline
\end{tabular}

Notes: The second follow-up survey for the 2010 cohort was conducted on a reduced (randomly selected) sample of 800 individuals. Out of those, the survey team was able to interview 634 individuals (79.5 percent) who were also interviewed at baseline.

The sampling procedures resulted in a study sample of 4677 individuals across all three cohorts at baseline, see Table 2. For the first follow-up surveys, we were able to track and successfully interview 88 percent of the baseline survey respondents, yielding a panel for analysis of 4101 individuals. ${ }^{21}$ Because training courses vary in length from one to three months, the follow-up survey examines outcomes nine to eleven months after the end of the training. The EF itself conducts follow-ups with a sample of participants up to six months after the training to verify employment and earnings. This is also the time point when providers receive their last payment installment. Hence, our first follow-up survey occurs three to five months after the training evaluation and the treatment group's last contact with the program.

\footnotetext{
20 Oversubscription was necessary to obtain a sufficiently large "quasi"experimental control group as detailed in the description of the applicant sampling below. The survey team was instructed to drop the event from the sample if there were not at least three rejected candidates who could be sampled for the control group (i.e., at least three candidates that fell within 20 percent of the threshold score).
}

\footnotetext{
21 The reasons given for loss to follow-up for the 2010 and 2011 cohorts include: inability to track the household (11 percent), no one in the household during multiple visits (15 percent), refusal (8 percent), respondent migrated for work within Nepal or abroad (8 percent), respondent migrated after marriage (10 percent), or other (40 percent).
} 


\subsection{Sample characteristics}

We present an overview of baseline characteristics in Table 3. Eligibility to apply for EF-sponsored training courses was restricted by age, education level, and poverty status; therefore, individuals in our sample are on average young, low educated and relatively poor. For the pooled sample (i.e., 2010-2012 cohorts), the study population has an average age of 24 years and is 63 percent female. A total of 38 percent of individuals have either have no education or only primary education. Approximately 61 percent of the sample engaged in some incomegenerating activity in the month prior to the survey. When we restrict to non-farm income-generating activities, the employment rate falls to 30 percent. The average number of hours worked in the month previous to the survey was 69 . At baseline, the average monthly earnings were 1269 NRs in the month prior to the survey (equivalent to about 17 USD). This figure appears low as it represents the average earnings over the entire study population of 4677 individuals, including those with zero earnings. Earnings conditional on any income generating activity were 2082 NRs. Only 18 percent earned more than 3000 NRs per month, a level deemed to represent "gainful" employment. Furthermore, only 18 percent of the sample was already engaged in the same trade as the training to which they applied, denoted as "trade-specific income-generating activity (IGA)", indicating that a significant minority of applicants had been looking to upgrade existing skills.

Generally, women have lower paid employment levels and earnings at baseline. Forty-seven percent of women engage in activities inside the house that yield some income (e.g., self-employment activities), while only 36 percent of the women engage in paid activities outside the house. In contrast, 59 (69) percent of men engage in paid activities inside (outside) the house. Also, men (69 percent) are more likely than women (56 percent) to carry out unpaid work outside the house (e.g., helping relatives); however, more women carry out unpaid work inside the house (e.g., household chores, child care). Almost all women ( 94 percent) work in the household without pay for at least $5 \mathrm{~h}$ a week, whereas this is only true for 61 percent of men. Furthermore, 55 percent of the women work more than $20 \mathrm{~h}$ per week inside the house without pay, which is only true for 12 percent of the men in our sample.

\section{Study design}

Admission to the program was based on a calculated score for each applicant and coupled with a course-specific threshold score. For each course, applicants with scores above the threshold were assigned to the training program, whereas applicants whose scores fell below the threshold were not assigned to the program. To form a sufficiently large quasi-experimental control group, training providers were advised to shortlist at least 50 percent more candidates than the number of spaces available in the training event. The assignment procedure followed streamlined guidelines, including a detailed scoring rubric, instructions for ranking the shortlisted candidates by score, and selecting the topscoring candidates for admission to the program.

The individual score used in ranking candidates consisted of five subscores based on: (a) applicants' trade-specific education (prerequisite, 15 points), ${ }^{22}$ (b) applicants' economic status (up to 20 points), (c) applicants'

\footnotetext{
22 Applicants had to fulfill course specific prerequisites (e.g., literacy, certain trade-specific knowledge or experience) to be eligible for the ranking procedure. If an applicant did not fulfill these prerequisites, he was then removed from the selection procedure. If applicants fulfilled the prerequisites, they then received 15 points as their first score-component. In exceptional cases (approx. 9 percent of the sample) this rule was not adhered to, and candidates received 0,5 , or 10 points.
}

social caste, gender, and special circumstances (up to 25 points), (d) development status of applicants' district of origin (up to 10 points), and (e) a score determined by a selection committee during an interview procedure (up to 30 points). Sub-scores for the first four components were determined based on the information each applicant provided in his or her application form (shown in Fig. A1 in Appendix A). The application form lists the exact questions upon which the distribution of scores was based. Tables A1 and A2 show how these criteria were converted into numeric scores within each of the four categories. Based on the aggregated four-component score, candidates were short-listed and invited for an interview. The fifth sub-score was determined based on an interview with a three-to five-member committee comprised of representatives from the training institution and potential employers. Moreover, representatives of the survey firm and/or the donor institutions (e.g., EF, World Bank, etc.) were usually present to observe the procedure. The selection committee jointly decided on the fifth sub-score by assessing the candidate's commitment, motivation, attitude, aptitude, and clear vision for employment and enterprising. Eventually, the selection procedure yielded a total score for each individual by summing across the five components. Possible total scores ranged from 0 to 100.

Admission in each course was then based on candidates' decreasing rank; available seats were assigned starting with the top-scorer. Therefore, the threshold in each course was based both on the distribution of candidates' scores and on the number of pre-determined available seats. Because the distribution of scores and the number of seats determine the selection process, the threshold score varies for each course, something we take into account in the empirical strategy described in Section 5. Fig. A2 displays a sample ranking form used by training providers. ${ }^{23}$ Although eligibility for training, based on the actual score, influenced the likelihood of training course enrollment, individual assignment to training was not automatic as it was originally envisioned for two main reasons: noncompliance and manipulation of the assignment procedure. We discuss the implications of these two factors in the remainder of this section.

As we examined the compliance with the selection process, we found that approximately 30 percent of the group assigned to the program did not take-up the training opportunity (possibly due to taking up other training or employment opportunities), whereas 32 percent of the nonassigned applicants did. These take-up numbers can be explained by a simple process in which seats not taken by individuals assigned to training were then given to individuals who were not originally assigned to training but rather next in line based on the ranking form. In the regression discontinuity estimation setup we use, an important step is to examine whether and how the probability of treatment jumped at the threshold. To account for the course-specific threshold, we subtract each individual's assignment score by the course-specific threshold score, whereby we obtain a standardized relative score around the cut-off of zero. We then plot the probability of treatment against the relative assignment score. Fig. 3's left graph shows the results of this procedure. The plot reveals a clear jump in the probability of program participation at the cut-off. As expected, the jump is less than one, a fact that we incorporate in the estimation strategy we follow.

To assess possible manipulation of the admission procedure, we plot the density of the relative score (shown in the left graph of Fig. 4). The plot reveals discontinuities in the distribution of the score around zero, which suggests that candidates' scores may have been manipulated to shift certain individuals across the assignment cut-off. In our scenario, such precise manipulation of the score was virtually impossible for candidates themselves, as it would have required access to the ranking form

\footnotetext{
23 Data in each column approximately represents the distribution of the respective component in the full sample. In this example, 15 seats were available and the score of the 15th ranked person on the list was 73. Hence, in this example, 73 would be the threshold score for this particular course.
} 
Table 3

Balance of covariates and outcome variables at baseline (full sample).

\begin{tabular}{|c|c|c|c|c|c|c|c|c|c|c|c|c|c|c|c|}
\hline \multirow[t]{2}{*}{ Variable } & \multicolumn{7}{|c|}{ Baseline Means } & \multicolumn{4}{|c|}{ Differences (Original Score) } & \multicolumn{4}{|c|}{ Differences (Reconstructed Score) } \\
\hline & All & Women & Men & Non-treated & Treated & Non-assigned & Assigned & LATE & & ITT & & LATE & & ITT & \\
\hline \multicolumn{16}{|l|}{ Demographics } \\
\hline Age & 24.32 & 24.66 & 23.72 & 24.39 & 24.27 & 24.34 & 24.31 & -1.21 & (1.53) & -0.32 & $(0.42)$ & $-4.37^{* * * *}$ & (1.35) & $-1.39^{* * *}$ & $(0.41)$ \\
\hline Primary Education or Less $(1=$ Yes $)$ & 0.38 & 0.43 & 0.29 & 0.39 & 0.37 & 0.35 & 0.39 & -0.16 & $(0.12)$ & -0.04 & $(0.03)$ & -0.12 & $(0.09)$ & -0.04 & $(0.03)$ \\
\hline Men $(1=$ Yes $)$ & 0.37 & 0 & 1 & 0.37 & 0.37 & 0.36 & 0.37 & $0.38^{* * *}$ & $(0.14)$ & $0.10^{* * * *}$ & $(0.04)$ & 0.00 & $(0.10)$ & 0.00 & $(0.03)$ \\
\hline Dalit $(1=$ Yes $)$ & 0.08 & 0.08 & 0.08 & 0.10 & 0.07 & 0.09 & 0.08 & $-0.38^{* * *}$ & $(0.08)$ & $-0.10^{* * *}$ & $(0.02)$ & $-0.11^{* *}$ & $(0.06)$ & $-0.03^{*}$ & $(0.02)$ \\
\hline Janjati (1 = Yes) & 0.46 & 0.42 & 0.51 & 0.41 & 0.49 & 0.42 & 0.47 & 0.09 & $(0.14)$ & 0.02 & $(0.04)$ & 0.04 & $(0.11)$ & 0.02 & $(0.03)$ \\
\hline Muslim (1 = Yes) & 0.03 & 0.03 & 0.02 & 0.02 & 0.03 & 0.02 & 0.03 & 0.01 & $(0.04)$ & 0.00 & $(0.01)$ & 0.04 & $(0.04)$ & 0.01 & $(0.01)$ \\
\hline \multicolumn{16}{|l|}{ Outcome Variables } \\
\hline Any IGA $(1=$ Yes $)$ & 0.61 & 0.52 & 0.77 & 0.59 & 0.63 & 0.59 & 0.62 & 0.11 & $(0.12)$ & 0.03 & $(0.03)$ & -0.04 & $(0.10)$ & -0.01 & $(0.03)$ \\
\hline Any non-farm IGA (1 = Yes) & 0.30 & 0.19 & 0.47 & 0.28 & 0.31 & 0.27 & 0.31 & $0.20^{*}$ & $(0.10)$ & $0.05^{*}$ & $(0.03)$ & -0.03 & $(0.09)$ & -0.01 & $(0.03)$ \\
\hline Non-farm wage IGA (1 = Yes) & 0.19 & 0.08 & 0.39 & 0.18 & 0.20 & 0.16 & 0.20 & $0.25^{* * *}$ & $(0.12)$ & $0.07^{* * *}$ & $(0.03)$ & 0.07 & $(0.09)$ & 0.02 & $(0.03)$ \\
\hline Non-farm self IGA (1 = Yes) & 0.09 & 0.10 & 0.09 & 0.09 & 0.09 & 0.09 & 0.10 & 0.07 & $(0.09)$ & 0.02 & $(0.02)$ & -0.02 & $(0.07)$ & -0.01 & $(0.02)$ \\
\hline Trade-specific IGA (1 = Yes) & 0.18 & 0.11 & 0.29 & 0.17 & 0.18 & 0.15 & 0.19 & 0.11 & $(0.09)$ & 0.03 & $(0.03)$ & -0.11 & $(0.08)$ & -0.04 & $(0.02)$ \\
\hline Hours worked in past month & 69.26 & 47 & 108 & 66 & 71 & 63 & 72 & $40^{* * *}$ & (19) & $11^{* *}$ & (5) & -1 & (18) & -0 & (6) \\
\hline Earnings & 1269 & 770 & 2138 & 1254 & 1280 & 1180 & 1303 & $851^{*}$ & (512) & 221 & (140) & -44 & (407) & -13 & (128) \\
\hline Logged earnings & 3.29 & 2.43 & 4.80 & 3.15 & 3.39 & 3.03 & 3.39 & 1.37 & $(0.96)$ & 0.36 & $(0.26)$ & 0.15 & $(0.73)$ & 0.05 & $(0.23)$ \\
\hline Earnings > 3000 NRs. $(1=$ Yes $)$ & 0.18 & 0.10 & 0.34 & 0.18 & 0.19 & 0.16 & 0.19 & $0.16^{*}$ & $(0.09)$ & $0.04 *$ & $(0.02)$ & 0.01 & $(0.07)$ & 0.00 & $(0.02)$ \\
\hline Earnings, conditional on any IGA & 2082 & 1491 & 2774 & 2127 & 2054 & 2009 & 2109 & 943 & (735) & 256 & (209) & 201 & (608) & 57 & (190) \\
\hline \multicolumn{16}{|l|}{ Hours/week working ... } \\
\hline Unpaid, inside house > 5 ( $1=$ Yes $)$ & 0.82 & 0.94 & 0.61 & 0.81 & 0.82 & 0.79 & 0.83 & 0.04 & $(0.10)$ & 0.01 & $(0.03)$ & -0.02 & $(0.06)$ & -0.01 & $(0.02)$ \\
\hline Unpaid, inside house $>10$ ( $1=$ Yes $)$ & 0.63 & 0.82 & 0.31 & 0.62 & 0.64 & 0.60 & 0.65 & -0.00 & $(0.13)$ & -0.00 & $(0.04)$ & -0.10 & $(0.09)$ & -0.03 & $(0.03)$ \\
\hline Unpaid, inside house $>20(1=$ Yes $)$ & 0.39 & 0.55 & 0.12 & 0.39 & 0.40 & 0.38 & 0.4 & -0.13 & $(0.11)$ & -0.03 & $(0.03)$ & -0.09 & $(0.09)$ & -0.03 & $(0.03)$ \\
\hline Unpaid, outside house $>0(1=$ Yes $)$ & 0.61 & 0.56 & 0.69 & 0.61 & 0.61 & 0.60 & 0.61 & 0.18 & $(0.12)$ & $0.05^{*}$ & $(0.03)$ & 0.07 & $(0.09)$ & 0.02 & $(0.03)$ \\
\hline Paid, inside house $>0(1=$ Yes $)$ & 0.52 & 0.47 & 0.59 & 0.52 & 0.52 & 0.51 & 0.52 & 0.04 & $(0.12)$ & 0.01 & $(0.03)$ & -0.15 & $(0.10)$ & -0.05 & $(0.03)$ \\
\hline Paid, outside house > 0 ( 1 = Yes $)$ & 0.48 & 0.36 & 0.69 & 0.45 & 0.49 & 0.45 & 0.49 & 0.04 & $(0.12)$ & 0.01 & $(0.03)$ & 0.00 & $(0.10)$ & 0.00 & $(0.03)$ \\
\hline
\end{tabular}

Notes: Non-farm wage IGA and Non-farm self IGA are only available for 2011 and 2012 cohorts. 


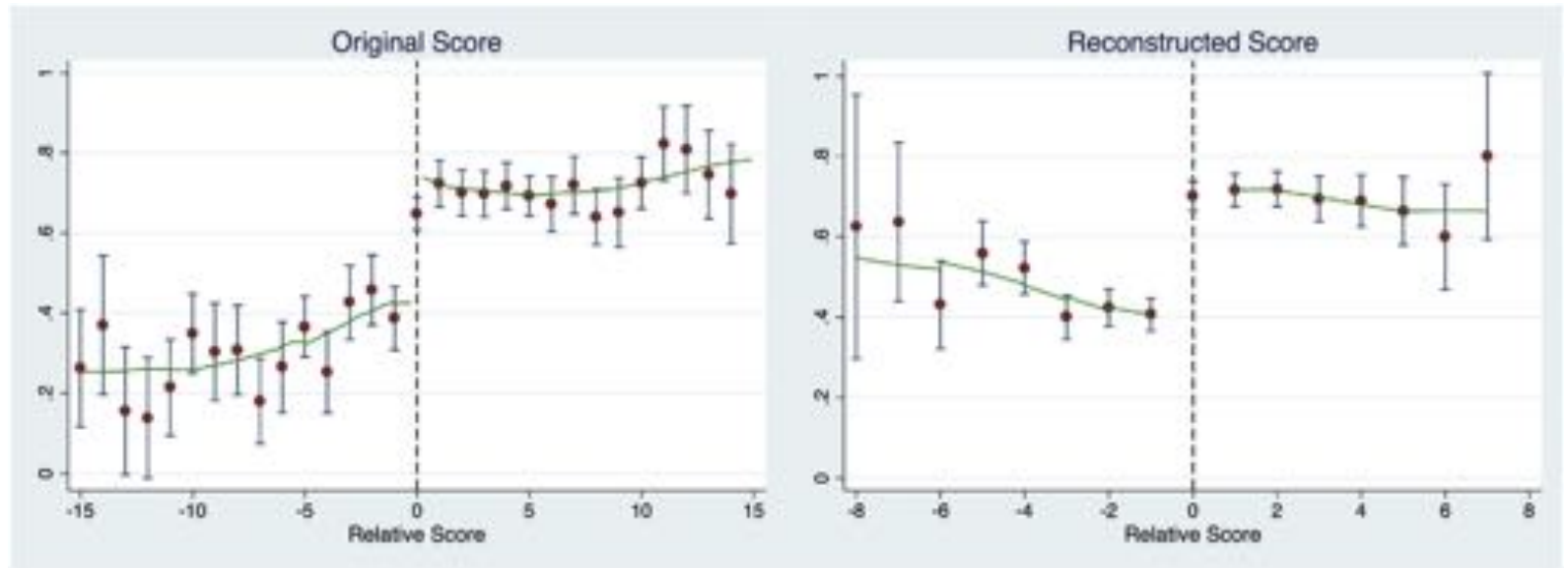

Fig. 3. Probability of program participation.
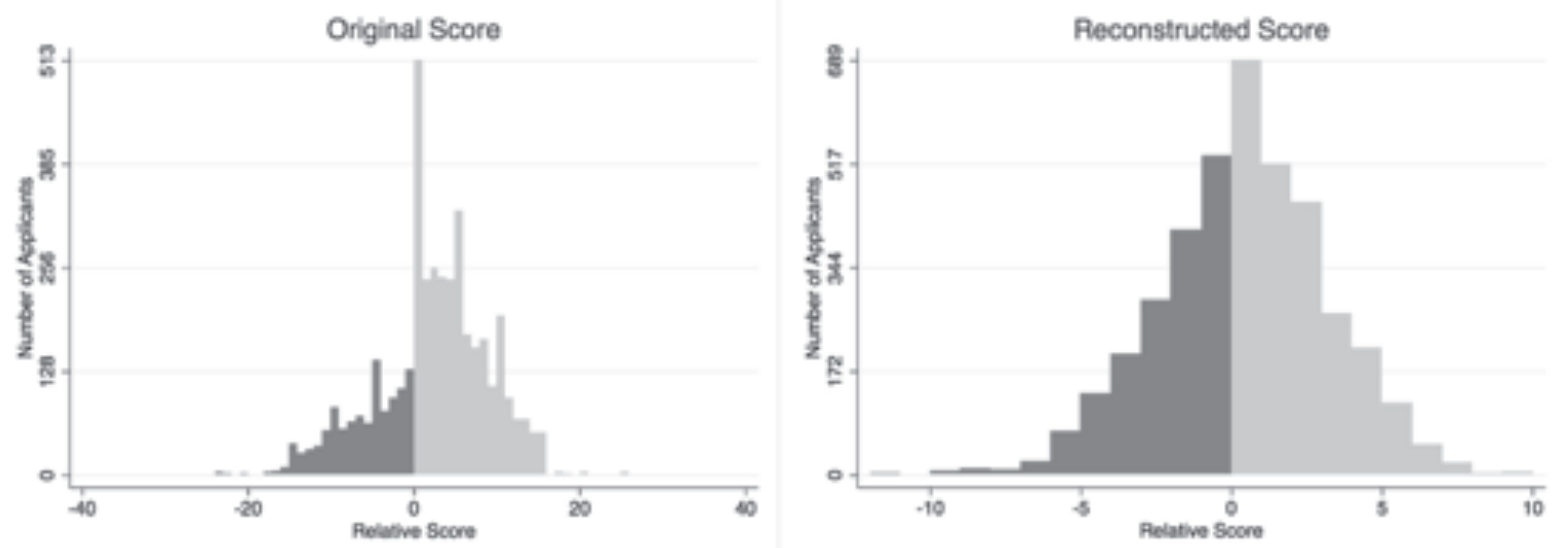

Fig. 4. Density of forcing variable.

after the official selection procedure was completed and the coursespecific threshold score was determined. ${ }^{24}$ In contrast, providers may have had the opportunity to precisely alter the scores of those candidates who seemed favorable to them. ${ }^{25}$ Although the selection committee included several persons from different interest groups and was designed to avoid this type of manipulation on a large scale, we cannot rule out the possibility that providers were able to manipulate the ranking sheet after the official selection procedure was completed. Because possible manipulation of the score can bias our estimates, we specifically address this manipulation issue by reconstructing the assignment score, which we describe in more detail below.

\footnotetext{
${ }^{24}$ Lee and Lemieux (2010) distinguish between precise and imprecise manipulation. While applicants were certainly able to manipulate the information they gave in the application form, aiming to raise their score, the forms were filled out long before the course threshold was determined, which only happened once all candidates were interviewed, which, as mentioned earlier, occurred after the application forms were submitted to the providers. Applicants' control over their score was therefore imprecise, which is actually what sorts them randomly around the cut-off. It is, therefore, not a threat to internal validity and not likely to have caused the discontinuity in our graph (Lee and Lemieux, 2010).

${ }^{25}$ Based on the above described payment scheme, providers had a motive to select candidates for the program who seem most employable or most disadvantaged. Also, favoritism or bribes from otherwise rejected candidates may have played a role in the manipulation.
}

\section{Empirical strategy}

To estimate program effectiveness on labor market outcomes, we use a non-parametric regression discontinuity strategy by running local linear regressions. Specifically, we estimate local average treatment effects (LATE) for the people who comply with the assignment status, intent-to-treat (ITT) effects, and heterogeneous effects by gender and trade within these two frameworks. In the following section, we describe the estimation strategy, the bandwidth selection, and how we reconstruct the assignment score. ${ }^{26}$

\subsection{Treatment effect estimators}

Local Average Treatment Effects (LATE). To address imperfect compliance to treatment, we employ a fuzzy regression discontinuity setup similar to the one proposed by Hahn et al. (2001). We run the following first-stage equation:

$D_{i}=\beta_{0}+\beta_{1} T_{i}+\beta_{2} X_{i}+\beta_{3}\left(X_{i}-t_{c}\right)+\beta_{4} T_{i}\left(X_{i}-t_{c}\right)+\varepsilon_{i}$,

where the treatment dummy $D_{i}$ indicates whether or not an applicant $i$ has received training, and $T_{i}$ is the excluded instrument, specifying whether an applicant has been assigned to training (i.e., whether the absolute assignment score $X_{i}$ of the applicant is greater than or equal to

\footnotetext{
${ }^{26}$ We follow the practical guidelines for regression discontinuity designs in Imbens and Lemieux (2008) and Lee and Lemieux (2010).
} 
the threshold score $t$ of the respective course $c$ he or she applied to). Furthermore, the forcing variable $\left(X_{i}-t_{c}\right)$ is the applicant's relative assignment score (i.e., it is the difference between an applicant's absolute assignment score and the threshold score $t_{c}$ of the course). The predicted values of $D_{i}$ are then used to run a second stage equation:

$Y_{i}=\gamma_{0}+\gamma_{1} D_{i}+\gamma_{2} X_{i}+\gamma_{3}\left(X_{i}-t_{c}\right)+\gamma_{4} D_{i}\left(X_{i}-t_{c}\right)+\mu_{i}$,

where $\gamma_{1}$ captures the local average treatment effect or the treatment effect for the compliers, and coefficients $\gamma_{3}$ and $\gamma_{4}$ represent the different slopes of the linear regression line left and right of the cut-off, respectively. In both equations, we have added the absolute assignment score as a control variable to account for the heterogeneity in the cut-off values across courses. ${ }^{27}$ It is important to note that the LATE estimate is not necessarily equal to the population average treatment effect, as it is based only on those candidates who comply with program assignment. In our sample, it is likely that compliers actually have higher returns to additional education compared to the average individual, an assumption that we further explain in the results section below. We interpret the LATE estimates as the upper bound estimates of the program impacts.

Intent-to-treat effects (ITT). The overall program effect (regardless of compliance) is of policy relevance. In an attempt to deal with the issue that the complier population might differ from the full sample, we employ an intent-to-treat regression discontinuity set-up in which we treat assignment to training as the treatment variable. We estimate the reduced form equation:

$Y_{i}=\delta_{0}+\delta_{1} T_{i}+\delta_{2} X_{i}+\delta_{3}\left(X_{i}-t_{c}\right)+\delta_{4} T_{i}\left(X_{i}-t_{c}\right)+\eta_{i}$,

where $T_{i}$ is again an indicator that represents whether an applicant has been assigned to training or not. The coefficient $\delta_{1}$ can be interpreted as the non-parametric local intention-to-treat effect (Lee and Lemieux, 2010) or the effect of training assignment on outcomes. This effect is likely lower than the population average treatment effect in our scenario because several candidates in the assigned group have not been trained, while several people in the non-assigned group have received training - likely biasing the estimate, $\delta_{1}$, towards zero. We, therefore, interpret the ITT effects as the lower bound estimates of program impacts.

Heterogeneous local average treatment effects (HLATE). Because treatment heterogeneity has important implications for eliciting the mechanisms through which the program operates, we estimate heterogeneous local average treatment effects (HLATE) based on the framework proposed by Becker et al. (2013). In particular, we estimate a two-stage procedure similar to the one described above with a second stage represented by the equation:

$Y_{i}=\gamma_{0}+\gamma_{1} D_{i}+\gamma_{2} X_{i}+\gamma_{3}\left(X_{i}-t_{c}\right)+\gamma_{4} D_{i}\left(X_{i}-t_{c}\right)+\gamma_{5} H_{i}+\gamma_{6} H_{i} D_{i}+\mu_{i}$,

where $H_{i}$ is an indicator for the subgroup. In the first stage, we use the predicted probability of training and its interaction with the subgroup indicator as instruments for $D_{i}$ and $H_{i} D_{i}$.

Additionally, we estimate heterogeneous ITT effects by adjusting Equation (3) to include the subgroup dummy $H_{i}$ and its interaction with the assignment indicator.

\footnotetext{
27 Based on suggestions in Cattaneo et al. (2016), we ran a graphical analysis that aggregates courses by the absolute threshold value to fully exploit all the information available by our multi-cutoff setup and explore how treatment effects may vary based on this on this (see Fig. A3 in Appendix A). Unfortunately, our sample size is not large enough to draw robust conclusions from this analysis as the confidence intervals in the graphs are relatively large. However, some of the graphs do suggest that the program may have been less effective in courses with relatively higher thresholds (i.e., courses that are likely to be located in particularly poor areas or frequented by particularly poor or disadvantaged applicants).
}

\subsection{Determining bandwidths}

For choosing the optimal bandwidth we follow Ludwig and Miller (2007) who suggest a cross-validation procedure to find the optimal balance between precision and bias. ${ }^{28}$ The cross-validation procedure chooses relatively large bandwidths in our sample, which in some cases include almost all candidates. We provide plots of the cross-validation functions for all our main outcomes in Figs. A4 and A5 of Appendix A. In a robustness section below, we further investigate the sensitivity of our estimates to the choice of bandwidth.

\subsection{Reconstructing the assignment score}

In an ideal case, we can examine the effect of training provision on outcomes by using the individual scores assigned by the providers during the interview procedure. The discontinuity in training assignment induced by the threshold score should theoretically generate an exogenous change in the probability of training, holding individual characteristics constant. However, and as mentioned previously in Section 4, we have a reason to believe that training providers were influencing the assigned scores possibly in response to the payment structure, which rewarded training completion and trainee placement over drop-outs and non-placed trainees. Therefore, manipulating the individual scores is likely to be related to unobserved individual characteristics, and, therefore, likely to bias the estimates of interest (McCrary, 2008). Which direction this bias takes is not obvious. It is likely that applicants who seemed particularly employable were favored by providers, in which case our estimates would be upward-biased. On the other hand, it is also conceivable that providers favored disadvantaged groups, as successfully training those groups was also incentivized with higher final payments. Finally, we cannot rule out the possibility that manipulation may have been the result of bribery or favoritism toward friends or relatives in which case the direction of possible bias could go in either direction. To determine the size and the direction of the potential bias, we run balancing tests on relevant characteristics at the baseline using the LATE and ITT specifications described in Section 5. Specifically, we examine the balancing of the outcome variable of interest at baseline in response to potentially influential characteristics such as age, education, gender, and ethnicity, which are likely to determine labor market outcomes. We report these balance tests in Table 3. The difference tests reveal that the initial assignment, based on the original scores, does not perform very well in balancing relevant covariates or labor market potential at baseline. Assigned individuals are more likely to be male, less likely to be of Dalit ethnicity, more likely to have engaged in a non-farm wage-employment activity in the past month, more likely to have worked more monthly hours, and more likely to exhibit higher initial earnings. In accordance with the incentivized payment structure, providers seem to have shifted those candidates across the threshold who appear to have been more employable. Moreover, given the imbalances of gender and Dalit ethnicity, which are in contradiction with the EF incentives to focus training on vulnerable groups, it seems possible that providers may have used score manipulation as a risk reduction or risk diversification strategy. Overall, we conclude that using the original score will most likely bias our results upwards - for the estimation of treatment effects-as a result of its manipulation.

To overcome this challenge, we follow the approach by Miller et al. (2013) who reconstructed the 'actual' individual-specific score from survey data. Currie and Gruber (1996a, b), Cutler and Gruber (1996), and Hoxby (2001) also follow this approach. As we cannot exactly be sure which of the sub-scores have been subject to manipulation by the training providers, we reconstruct all five of them and later aggregate them to

\footnotetext{
${ }^{28}$ We apply the user-written program rdbwselect provided by Calonico et al. (2014) to estimate the cross-validation functions that determine our bandwidths.
} 
obtain a new total score. We use data from candidates' original application forms to assign three out of five sub-scores. As described above, this data is necessarily free of precise manipulation, as the forms were filled out long before the ranking sheet and the course thresholds were determined. Fig. A1 in Appendix A shows the section of the application form that contains the relevant applicant information. We assign points based on this information as well as the exact scoring rubric used for the original score (see Table A1 and A2).

For the remaining two score components, we follow two different strategies. The first sub-score refers to the applicants' trade-specific education and was initially meant to be 15 for all short-listed candidates. Usually, if candidates did not fulfill the course-specific education prerequisites, they were not eligible for short-listing and immediately rejected. However, in exceptional cases (approximately nine percent of the sample) this criterion was not adhered to and instead applicants received 0,5 , or 10 points. We, therefore, reconstruct the first component based on an OLS specification that regresses the original first sub-score on candidates' general and course-specific education attainments, each interacted with a set of course dummies. To avoid the estimation bias induced by the aforementioned manipulation, we remove all candidates from the model who fall within five index scores of the cut-off (where most of the manipulation took place). ${ }^{29}$ We then predict the outcomes (including all candidates) and round them to values that are factors of five in order to reflect the original distribution of the first sub-score.

For the fifth score component, the selection committee was supposed to assess employability and non-cognitive qualities of the applicants to rate their overall probability to successfully complete the program. If precise manipulation was applied to an applicant's fifth sub-score, it was likely carried out vis-a-vis the sum of the other four sub-scores, which were available at the time of the interview. Given the scoring rubric in Table A1, candidates who are better educated, less poor, less disadvantaged, and from a more developed district are ranked relatively lower, but may have higher potential to be successful in the labor market after training completion and, therefore, might be the more interesting candidates for the providers. If this is indeed the case, the incentive for manipulation would be positively correlated with the first score component and negatively correlated to the following three sub-scores. In other words, the higher (lower) the first (second, third, and forth) component-score, the higher the incentive is for the provider to secretly add points onto the applicant's fifth score in order to shift him or her over the threshold. In order to substantiate these considerations, we regress the manipulated fifth sub-score on the first four sub-scores and a set of course dummies. Results are presented in Table A3 of Appendix A. We find that the first four score components predict the interview score as expected (Column 1 and 2). In Column 3 we also add all possible interaction terms created from the four sub-scores of the model, which slightly improve its predictive power. Assuming that candidates' commitment and motivation are not (perfectly) correlated with education, being poor or being disadvantaged, the residual of this regression should now contain some relevant information on the selection committees' assessments of the candidates' aptitudes. We, therefore, use the predicted residual of the model in Column 3 to create the fifth component in the reconstructed assignment score.

Because the points in the first four components were originally distributed by factors of five, we divide all score components by five to smooth the score and to minimize the heaping at multiples of five found in the original score. The final reconstructed score, therefore, ranges from 0 to 20 .

\footnotetext{
29 The treatment effects presented below are qualitatively and quantitatively robust to a number of alternative specifications, including the use of a different range of index scores to drop individuals, or adding other baseline characteristics to the model.
}

\subsection{Simulating the assignment threshold}

The assignment indicator we need for our analysis is not only determined by the individual scores, but also by the course-specific threshold score, which is likely to be affected by the manipulation of providers as well. ${ }^{30}$ To construct a valid instrument, we re-estimate the threshold scores for each course following the approach proposed by Miller et al. (2013). ${ }^{31}$ The authors' proposed approach depends on finding the optimal assignment variable based on a simulation exercise that maximizes the number of compliers given the reconstructed individual scores in a given course. Specifically, for each course, we run a set of simplified first stages similar to the one in Equation (1). We subsequently alter the threshold score, used to create the assignment dummy variable, $T_{i}$, from the lowest to the highest possible value. We then keep the threshold rule out of all possible assignment thresholds based on the specification that yields the largest $\mathrm{R}^{2}$ for the respective course. Based on this optimal threshold, we proceed with calculating a reconstructed relative score, which serves as our new forcing variable.

\subsection{Balancing performance of the reconstructed score}

Our empirical approach assumes that no individual characteristics (other than vocational training enrollment) that could influence the outcomes of interest vary discontinuously across the estimated eligibility thresholds. As a first cut, and to assess whether the reconstruction of the score improves the differential sorting around the cut-off, we provide graphical evidence with respect to the density of the new forcing variable in Fig. 4 (right graph). The density plot is significantly improved and does not appear to be discontinuous around the cut-off. We also employ the same balancing tests as before, now using the reconstructed score variable. Table 3's last two columns report the results. The new score successfully removes the imbalances we previously detected in all outcome variables as well as in the demographic characteristics at the baseline. Consistent with our assumption, estimates are not generally distinguishable from zero, except for the variables of age and Dalit ethnicity. In Figs. 5 and 6, we present additional graphical evidence that outcomes and demographic characteristics are continuous around the cut-off of the running variable at baseline, except age and primary education. Age, being Dalit, and primary education are (practically) time-invariant characteristics in our sample. We, therefore, address the remaining unbalancing by following an estimation strategy on differenced outcomes.

Additionally, we show evidence in Figs. 5 and 7 that the subgroup indicators we use to estimate heterogeneous treatment effects (i.e., an applicant's gender and the trade of training) are continuous across the threshold. This continuity across the threshold confirms that assignment status is not correlated with interaction variables around the cut-off, which is an important condition necessary for the estimation of unbiased heterogeneous treatment effects in the regression discontinuity setup (Becker et al., 2013).

\section{Results}

\subsection{Program effects on employment and earnings}

We now turn our attention to the impact on the combined 2010, 2011 and 2012 samples based on the specifications described in Section 5. Table 4, Panel A shows the local average treatment effects (LATE) estimated from Equations (1) and (2) - i.e., the effects the program had considering those individuals who complied with their assignment status - for employment and earnings on differenced outcomes using the

\footnotetext{
30 This is the case because the assignment threshold automatically moves with the distribution of the individual scores in each course.

31 The authors follow Chay et al. (2005).
} 


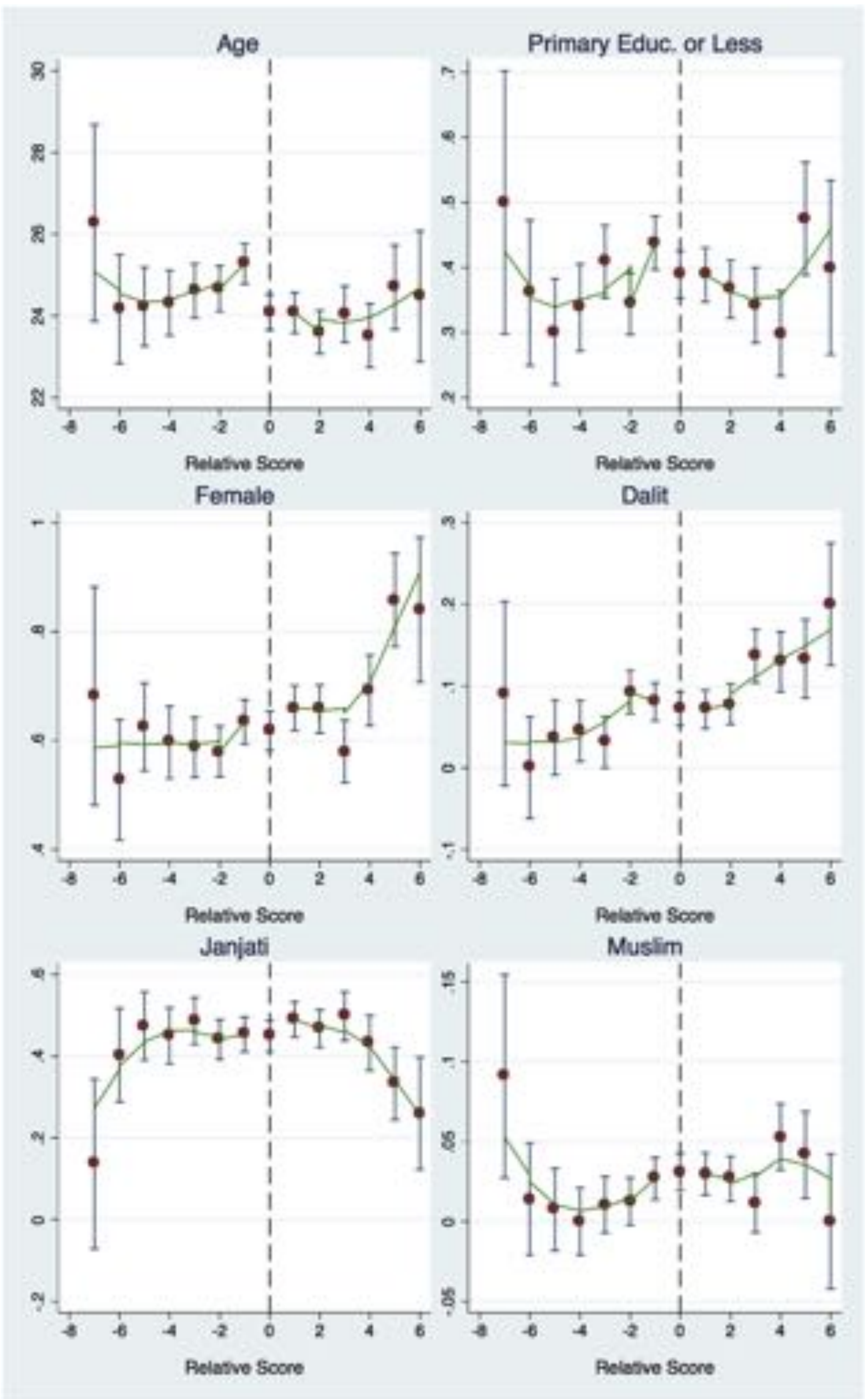

Fig. 5. Continuity of covariates around the cut-off at baseline. 


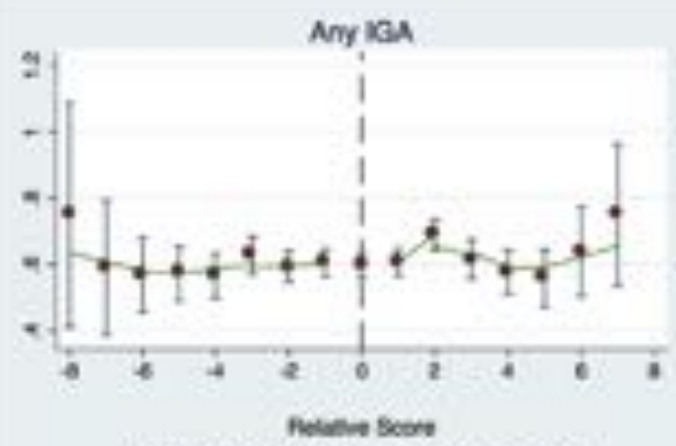

Amy Nosfarm Wage-employed IBA

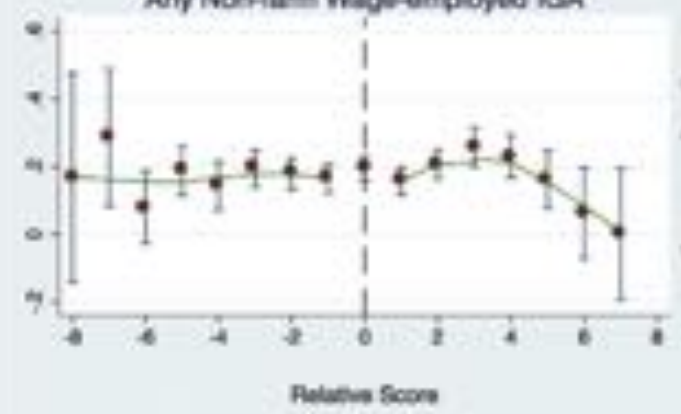

IQA Same Categery as Training
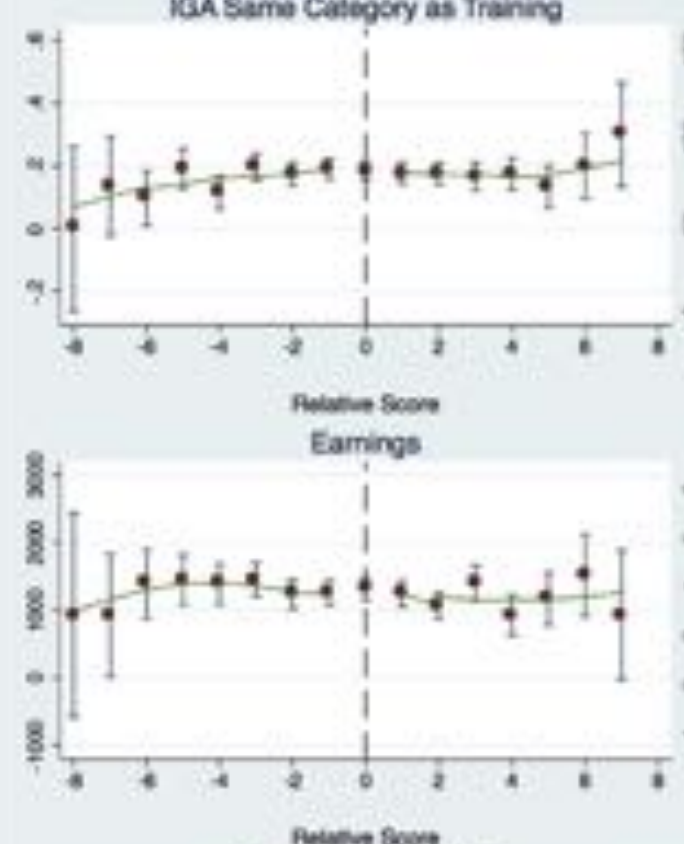

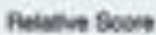
Eamings $>3000$ NAs

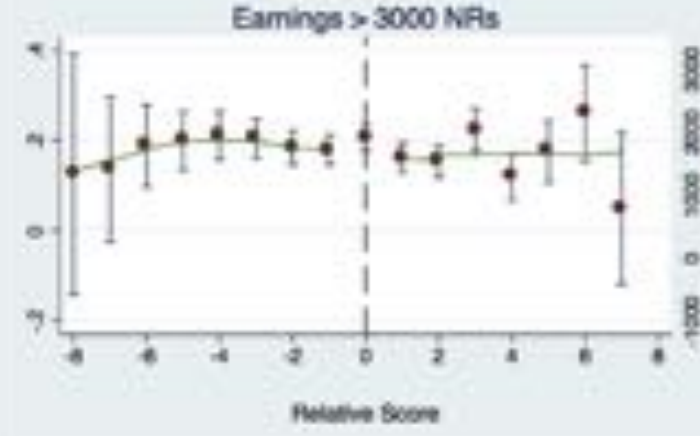

Any Non-tarm IGA

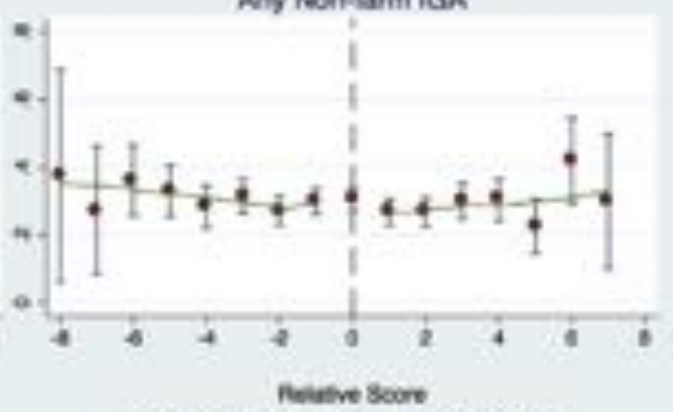

Any Nonfarm Settemployed ICA

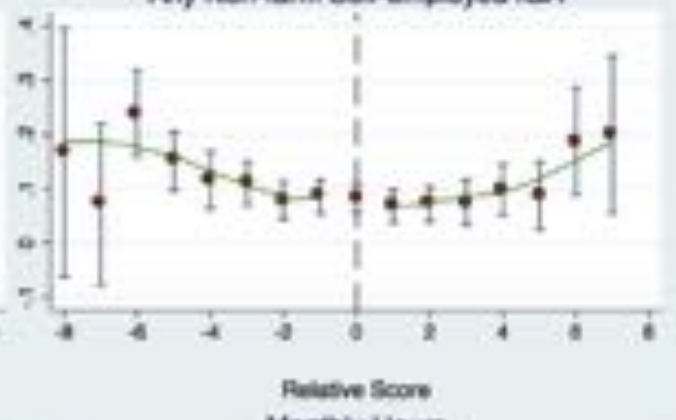

Monthy Hous

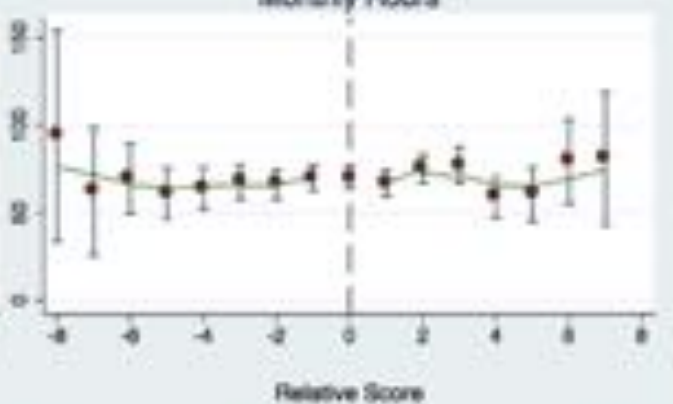

Log Earnings

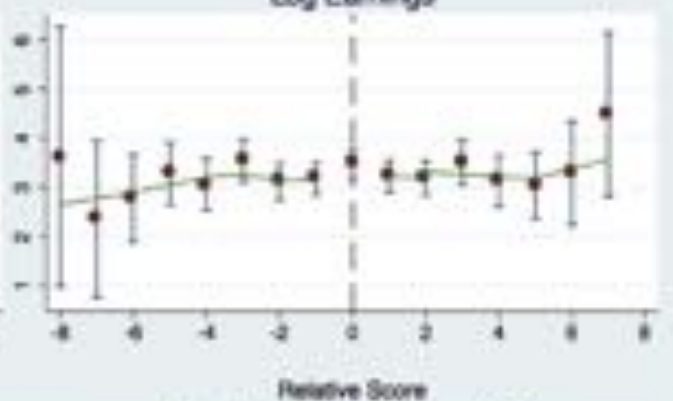

Earnings, Cond. on Any IGA

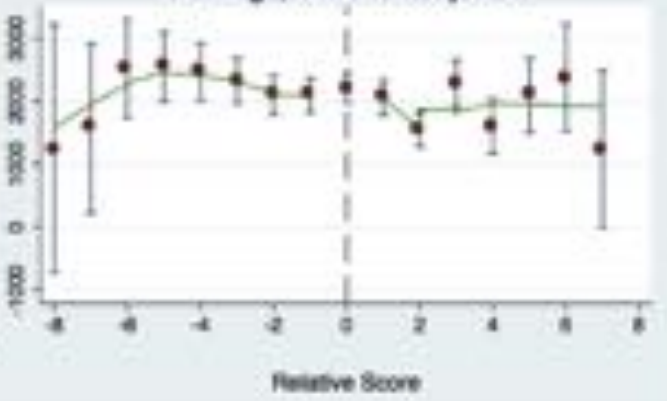

Fig. 6. Continuity of outcomes around the cut-off at baseline. 


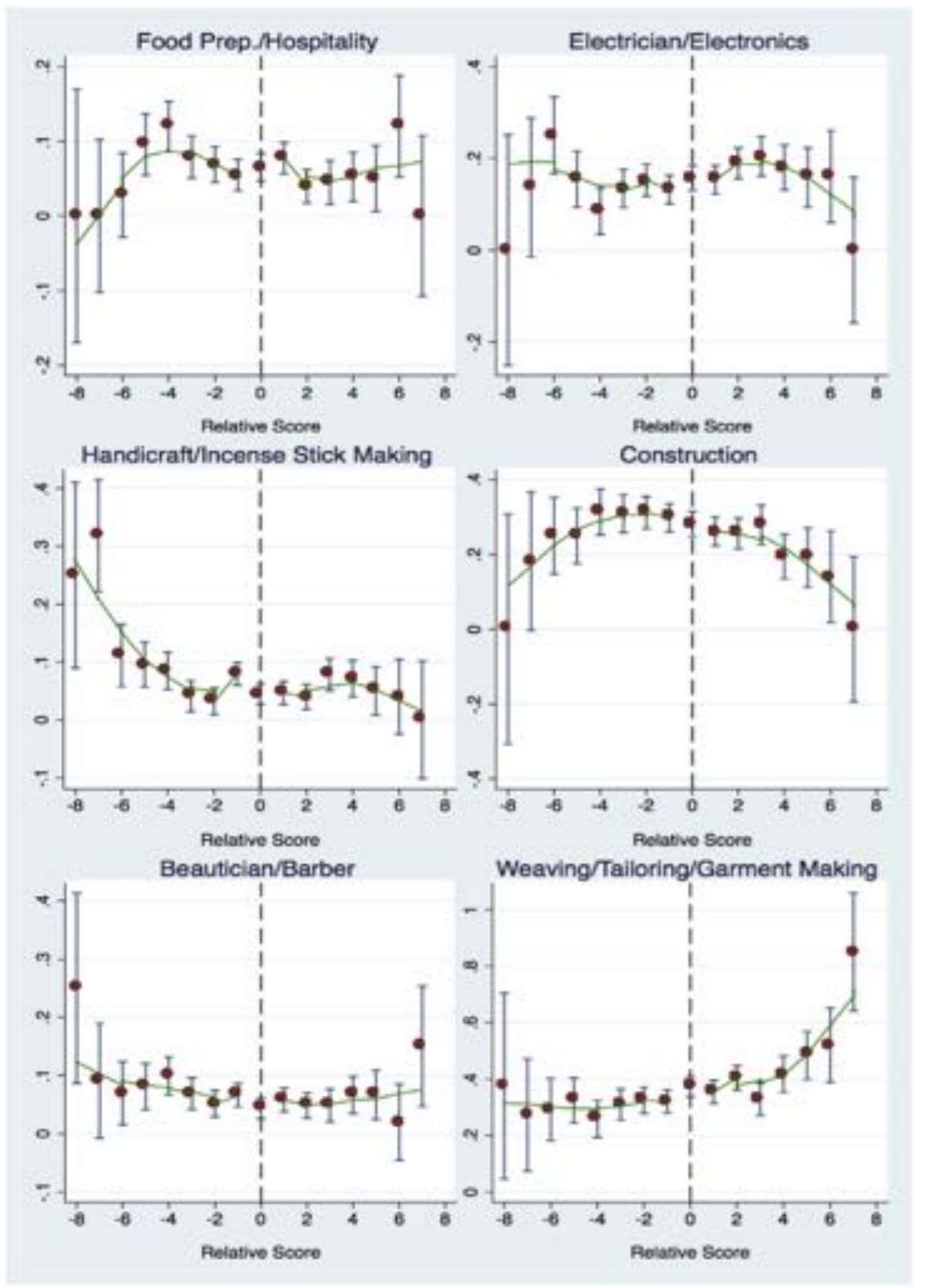

Fig. 7. Continuity of trade choices around the cut-off.

original score. We find relatively large estimates across all outcomes, including significant (conditional) employment effects of 22-61 percentage points, as well as average earning gains of more than 3000 NRs. The F-statistics (which range from 32 to 67 ) and the highly significant coefficients of the assignment variable $\left(\beta_{1}\right)$ presented in the same panel suggest a strong first stage. However, as pointed out earlier, the estimates are likely to be biased upwards because the possible manipulation of the original score variable led to unbalanced individual characteristics and outcome variables at baseline.

Therefore, in Panel B, we use the reconstructed score, which led to a significantly improved covariate balancing. The first stage is very strong with F-statistics ranging from 38 to 88 and coefficients of the assignment variable $\left(\beta_{1}\right)$ that are statistically significant at the 1-percent level. Comparing the effect sizes of Panels A and B (first rows, respectively) reveals that manipulation resulted in a strong upward bias in almost all outcomes. Using the corrected score, we no longer find evidence of a 
Table 4

Employment.

\begin{tabular}{|c|c|c|c|c|c|c|c|c|c|c|}
\hline & $\begin{array}{l}\text { Any IGA } \\
(1=\text { Yes })\end{array}$ & $\begin{array}{l}\text { Any non- } \\
\text { farm IGA } \\
(1=\text { Yes })\end{array}$ & $\begin{array}{l}\text { Non-farm } \\
\text { wage IGA } \\
(1=\text { Yes })\end{array}$ & $\begin{array}{l}\text { Non-farm } \\
\text { self IGA } \\
(1=\text { Yes })\end{array}$ & $\begin{array}{l}\text { Trade- } \\
\text { specific IGA } \\
(1=\text { Yes })\end{array}$ & $\begin{array}{l}\text { Hours } \\
\text { worked in } \\
\text { past month }\end{array}$ & Earnings & $\begin{array}{l}\text { Logged } \\
\text { earnings }\end{array}$ & $\begin{array}{l}\text { Earnings > } 3000 \\
\text { NRs. }(1=\text { Yes })\end{array}$ & $\begin{array}{l}\text { Earnings, } \\
\text { conditional on } \\
\text { any IGA }\end{array}$ \\
\hline & (1) & (2) & (3) & (4) & (5) & (6) & (7) & (8) & (9) & (10) \\
\hline \multicolumn{11}{|l|}{ Panel A } \\
\hline $\begin{array}{l}\text { LATE, DD } \\
\text { (Original } \\
\text { Score) }\end{array}$ & $\begin{array}{l}0.27^{*} \\
(0.15)\end{array}$ & $\begin{array}{l}0.52^{* * *} \\
(0.15)\end{array}$ & $\begin{array}{l}0.38^{* * *} \\
(0.15)\end{array}$ & $\begin{array}{l}0.22^{*} \\
(0.12)\end{array}$ & $\begin{array}{l}0.61^{* * *} \\
(0.14)\end{array}$ & $\begin{array}{l}75.92^{* * *} \\
(25.57)\end{array}$ & $\begin{array}{l}3074 * * * \\
(987)\end{array}$ & $\begin{array}{l}2.85^{*} \\
(1.55)\end{array}$ & $\begin{array}{l}0.43^{* * *} \\
(0.14)\end{array}$ & $\begin{array}{l}3179 * * \\
(1295)\end{array}$ \\
\hline First Stage & $\begin{array}{l}0.27 * * * \\
(0.03)\end{array}$ & $\begin{array}{l}0.26^{* * *} \\
(0.04)\end{array}$ & $\begin{array}{l}0.29 * * * \\
(0.04)\end{array}$ & $\begin{array}{l}0.29 * * * \\
(0.04)\end{array}$ & $\begin{array}{l}0.27 * * * \\
(0.03)\end{array}$ & $\begin{array}{l}0.27^{* * *} \\
(0.03)\end{array}$ & $\begin{array}{l}0.26 * * * \\
(0.04)\end{array}$ & $\begin{array}{l}0.23^{* * *} \\
(0.04)\end{array}$ & $\begin{array}{l}0.26^{* * *} \\
(0.04)\end{array}$ & $\begin{array}{l}0.28^{* * *} \\
(0.05)\end{array}$ \\
\hline F-statistic & 67.30 & 54.90 & 47.53 & 47.53 & 58.42 & 67.30 & 53.73 & 36.04 & 52.31 & 32.37 \\
\hline $\begin{array}{c}\text { Baseline } \\
\text { mean }\end{array}$ & 0.61 & 0.30 & 0.19 & 0.09 & 0.18 & 69.26 & 1271 & 3.27 & 0.18 & 2084 \\
\hline Bandwidth & 37 & 15 & 37 & 37 & 19 & 37 & 23 & 12 & 19 & 26 \\
\hline \multicolumn{11}{|l|}{ Panel B } \\
\hline $\begin{array}{l}\text { LATE, DD } \\
\text { (Reconstr. } \\
\text { Sc.) }\end{array}$ & $\begin{array}{l}0.13 \\
(0.10)\end{array}$ & $\begin{array}{l}0.31 * * * \\
(0.10)\end{array}$ & $\begin{array}{l}0.11 \\
(0.11)\end{array}$ & $\begin{array}{l}0.30^{* * *} \\
(0.12)\end{array}$ & $\begin{array}{l}0.40 * * * \\
(0.12)\end{array}$ & $\begin{array}{l}48.85^{* *} \\
(20.50)\end{array}$ & $\begin{array}{l}1754 * * \\
(696)\end{array}$ & $\begin{array}{l}1.75^{* *} \\
(0.87)\end{array}$ & $\begin{array}{l}0.31 * * * \\
(0.11)\end{array}$ & $\begin{array}{l}2025^{*} \\
(1115)\end{array}$ \\
\hline First Stage & $\begin{array}{l}0.32^{* * *} \\
(0.03)\end{array}$ & $\begin{array}{l}0.32^{* * * *} \\
(0.03)\end{array}$ & $\begin{array}{l}0.31 * * * \\
(0.04)\end{array}$ & $\begin{array}{l}0.30 * * * \\
(0.04)\end{array}$ & $\begin{array}{l}0.32 * * * \\
(0.03)\end{array}$ & $\begin{array}{l}0.32 * * * \\
(0.03)\end{array}$ & $\begin{array}{l}0.33^{* * *} \\
(0.04)\end{array}$ & $\begin{array}{l}0.32^{* * *} \\
(0.03)\end{array}$ & $\begin{array}{l}0.32^{* * *} \\
(0.03)\end{array}$ & $\begin{array}{l}0.30^{* * *} \\
(0.05)\end{array}$ \\
\hline F-statistic & 87.47 & 87.47 & 54.84 & 51.12 & 87.47 & 87.47 & 85.92 & 86.33 & 86.33 & 38.23 \\
\hline $\begin{array}{c}\text { Baseline } \\
\text { mean }\end{array}$ & 0.61 & 0.29 & 0.18 & 0.09 & 0.18 & 68.62 & 1260 & 3.27 & 0.18 & 2075 \\
\hline Bandwidth & 12 & 12 & 12 & 11 & 12 & 12 & 9 & 12 & 12 & 12 \\
\hline $\begin{array}{l}\text { Observations } \\
\text { Panel C }\end{array}$ & 4004 & 4004 & 2608 & 2606 & 4004 & 4004 & 3822 & 3838 & 3838 & 1931 \\
\hline $\begin{array}{l}\text { LATE, Level } \\
\text { (Reconstr. } \\
\text { Sc.) }\end{array}$ & $\begin{array}{l}0.09 \\
(0.08)\end{array}$ & $\begin{array}{l}0.33^{* * *} \\
(0.09)\end{array}$ & $\begin{array}{l}0.17 \\
(0.11)\end{array}$ & $\begin{array}{l}0.26^{* *} \\
(0.12)\end{array}$ & $\begin{array}{l}0.33^{* * *} \\
(0.10)\end{array}$ & $\begin{array}{l}48.08^{* *} \\
(21.01)\end{array}$ & $\begin{array}{l}1934^{* * *} \\
(745)\end{array}$ & $\begin{array}{l}1.80^{* *} \\
(0.81)\end{array}$ & $\begin{array}{l}0.32^{* * *} \\
(0.10)\end{array}$ & $\begin{array}{l}2686 * * \\
(1355)\end{array}$ \\
\hline First Stage & $\begin{array}{l}0.32^{* * *} \\
(0.03)\end{array}$ & $\begin{array}{l}0.34 * * * \\
(0.04)\end{array}$ & $\begin{array}{l}0.31^{* * *} \\
(0.04)\end{array}$ & $\begin{array}{l}0.31^{* * *} \\
(0.05)\end{array}$ & $\begin{array}{l}0.34^{* * *} \\
(0.04)\end{array}$ & $\begin{array}{l}0.32^{* * *} \\
(0.03)\end{array}$ & $\begin{array}{l}0.34 * * * \\
(0.04)\end{array}$ & $\begin{array}{l}0.32^{* * *} \\
(0.03)\end{array}$ & $\begin{array}{l}0.32^{* * *} \\
(0.03)\end{array}$ & $\begin{array}{l}0.29 * * * \\
(0.05)\end{array}$ \\
\hline F-statistic & 87.47 & 88.14 & 57.61 & 35.82 & 88.14 & 87.47 & 89.99 & 88.26 & 88.26 & 29.78 \\
\hline $\begin{array}{c}\text { Baseline } \\
\text { mean }\end{array}$ & 0.61 & 0.29 & 0.18 & 0.08 & 0.18 & 68.62 & 1261 & 3.27 & 0.18 & 2043 \\
\hline Bandwidth & 12 & 8 & 12 & 4 & 8 & 12 & 8 & 12 & 12 & 3 \\
\hline \multicolumn{11}{|l|}{ Panel D } \\
\hline $\begin{array}{l}\text { ITT, DD } \\
\text { (Reconst. Sc.) }\end{array}$ & $\begin{array}{l}0.04 \\
(0.03)\end{array}$ & $\begin{array}{l}0.10^{* * *} \\
(0.03)\end{array}$ & $\begin{array}{l}0.03 \\
(0.03)\end{array}$ & $\begin{array}{l}0.09 * * \\
(0.04)\end{array}$ & $\begin{array}{l}0.13^{* * *} \\
(0.04)\end{array}$ & $\begin{array}{l}15.41^{* *} \\
(6.45)\end{array}$ & $\begin{array}{l}572 * * \\
(227)\end{array}$ & $\begin{array}{l}0.57^{* * *} \\
(0.28)\end{array}$ & $\begin{array}{l}0.10^{* * *} \\
(0.03)\end{array}$ & $\begin{array}{l}598^{*} \\
(324)\end{array}$ \\
\hline \multicolumn{11}{|c|}{ Group means at follow-up (Within given Bandwidth of Panel B) } \\
\hline Non-treated & 0.69 & 0.46 & 0.28 & 0.16 & 0.30 & 98.36 & 2820 & 4.54 & 0.40 & 4157 \\
\hline Treated & 0.81 & 0.68 & 0.38 & 0.29 & 0.55 & 132.79 & 3780 & 6.13 & 0.57 & 4717 \\
\hline Non-assigned & 0.72 & 0.53 & 0.31 & 0.19 & 0.37 & 107.78 & 3035 & 4.96 & 0.43 & 4262 \\
\hline Assigned & 0.79 & 0.64 & 0.36 & 0.27 & 0.50 & 126.56 & 3634 & 5.84 & 0.55 & 4665 \\
\hline
\end{tabular}

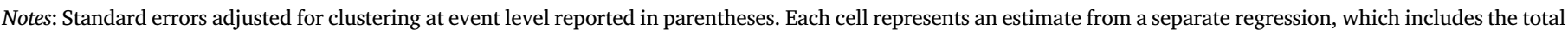

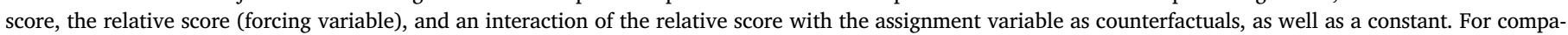

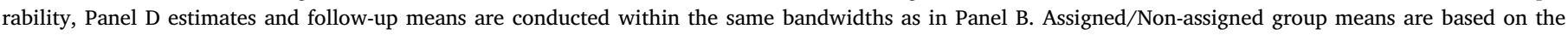

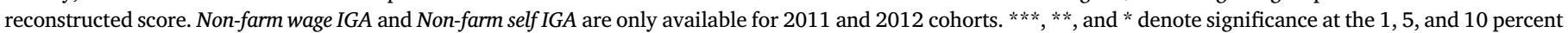
level.

statistically significant impact on the employment rate, measured by whether individuals self-report any income-generating activities in the past month (Column 1, Panel B). When we restrict attention to employment in all non-farm activities, we find a lower but still statistically significant increase (Column 2, Panel B). The rate of participation in nonfarm income-generating activities increases by 31 percentage points (from a base of 29 percent) as compared to 52 percentage points from using the manipulated score (Column 2, Panel A). Converting the results in percentage change terms, we find that the program increased non-farm employment by almost 94 percent. These impacts are not only statistically significant, but they are also economically meaningful. Disentangling these impacts into wage- and self-employment activities suggests that the effect is strongly driven by self-employment activities. The program increased non-farm self-employment by 30 percentage points, whereas we do not detect statistically significant impacts on nonfarm wage employment rates (Columns 3 and 4, Panel B). We also examine the trade-specific income generating activity (IGA) rate - the percent of individuals who find employment in the same trade as the training that they applied for - and we find impacts of 40 percentage points (Column 5, Panel B). The increase in the employment rate within the same occupational fields for which the individuals trained implies that the skills trainees acquired in the vocational training part of the program were useful in starting employment activities within their respective trades. The EF program also led to improvements in the underemployment rate (i.e., cases in which people are working fewer hours than they wish). Column 6 of Panel B shows that the EF-sponsored training courses increased hours worked in IGAs by $49 \mathrm{~h}$ per month (i.e., a 71 percent increase).

When we examine program impacts on monthly earnings using the corrected score, we find that effect sizes are about two-thirds of the estimates in Panel A. The reported results still show large program impacts (Columns 7 to 10, Panel B). We measure earnings as an individual's total earnings in the past month, including income from all IGAs, but not including unearned income. ${ }^{32}$ We observe a statistically significant increase in monthly earnings for the treatment group by 1754 NRs ( $\approx 23$ USD), from a baseline average of 1260 NRs. Once we

\footnotetext{
${ }^{32}$ If an individual did not work for pay in the past month, his/her earnings are recorded as zero.
} 
restrict earnings only to those individuals who engage in an income generating activity, we detect an increase in earnings by $2025 \mathrm{NRs}(\approx 27$ USD), from a baseline average of 2075 NRs. In percentage terms, the increases in earnings translate to 140 and 98 percent, respectively. With alternative measurements of earnings, we also detect large program impacts. To account for the highly skewed nature of earnings distributions, we examine for impacts on logged earnings and find very sizable increases. In a third approach, we consider the proportion of participants who earned a "decent living." The EF considers 3000 NRs per month ( $\approx 40$ USD) as "gainful employment" or "being productively employed." At baseline, only 18 percent of the sample was gainfully employed. The EF training program increased this rate by 31 percentage points.

In Panels $\mathrm{A}$ and $\mathrm{B}$, we use differenced outcomes to address the (remaining) disparities in participant characteristics we observed at baseline. In addition, the results reported in the discussion above are based on individuals who complied with their assignment status and, as a result, may differ from individuals in the full sample. In Panel C and D, we examine how altering these two features - that of differenced outcomes and the existence of compliers-affect our results. When comparing the estimates on differenced outcomes and on outcomes in levels, (Panel B versus C) using the reconstructed score, the difference in effect sizes is minor across most results. The most important difference we detect is on the variable that captures conditional earnings (Column 10, Panel C), which increases by approximately one-third compared to the estimate from the differenced outcome in Panel B. While the assigned group is slightly younger on average, they are also less likely to be Dalit than the rejected group. Older individuals may have been employed in a particular IGA for a longer time or, in general, may have more work experience, which is likely to lead to a higher level of earnings. On the other hand, individuals of Dalit ethnicity face substantial discrimination in the labor market, which likely makes them earn less compared to nonDalits. The reduced effect size when controlling for time-invariant factors suggests that ethnicity outweighs the differences in age.

Turning to Panel D, we examine the intent-to-treat (ITT) effects, based on Equation (3) in Section 5. We also provide graphical evidence of these effects in Fig. 8.

As expected, we see sizeable differences: all ITT coefficients are substantially lower as compared to the LATE estimates. Although the ITT effects are smaller in size, they still indicate that training led to a significant increase in non-farm self-employment and trade-specific employment of 9 and 13 percentage points, an average increase of $15 \mathrm{~h}$ per month of working time as well as an average rise in overall earnings of 572 NRs. The smaller effect sizes are to some extent due to the partial crossover between assignment groups (as we document above). Therefore, these coefficients can be interpreted as lower-bound estimates of the program effects.

Moreover, compliers in our sample may differ from non-compliers due to Nepal's labor market context, along with the program-specific targeting of particularly disadvantaged groups. Although the eligibility criteria of the program automatically exclude better-educated and nonpoor individuals, the sample of applicants is still quite diverse along various characteristics that might affect the magnitude of the return an applicant can expect from participation in the program: in caste, in gender, in educational attainment, and in baseline intensity of poverty. It is entirely possible that the complier-population may be a subgroup of individuals for whom the returns to participation are larger than for the overall sample. For example, individuals who comply with program assignment may be otherwise unable to secure a self-paid seat in a similar program due to extreme poverty or caste- and gender-based discrimination. At the same time, these particular groups of applicants likely also have lower baseline educational levels and higher returns to additional education as compared to the rest of the sample. Therefore, we interpret the complier-based LATE coefficient estimates as upper-bound estimates of the program's effects.

\subsection{Gender-disaggregated program effects}

We also examine program impacts disaggregated for men and women (shown in Tables 5 and 6). The results reveal striking differences in the program's effectiveness by gender. For all outcomes, except for the conditional and unconditional earnings variables, the LATE estimates are larger and significantly different for women as compared to men. Except for the earnings conditional on employment outcome, none of the effects for males are statistically significant. The coefficients are, in fact, negative for most of the outcomes. In contrast, most effects for females are statistically significant, except for non-farm wage-employment, and earnings conditional on employment. The ITT results paint a similar picture and, additionally, show weak evidence of non-farm wageemployment gains for women. In summary, women seem to gain on the extensive margin across most outcomes (i.e., employment rates, hours worked, and earnings) without significant gains on the intensive margin (i.e., conditional earnings). In comparison, men exhibit gains exclusively on the intensive margin.

Several factors could explain the differential gender impacts on employment outcomes. First, the EF introduced life-skills training for women, in 2010, in all of its training courses. Female students overwhelmingly responded positively to the life-skills training, often claiming that it was one of their favorite parts of the course. The skills learned and the positive experience in this life-skills training may contribute to the increased employment impact for women, which is line with the advice from experts in vocational training from around the world who increasingly advocate for the inclusion of life-skills in technical training programs. ${ }^{33}$ Because all women received life-skills training, we ultimately cannot disentangle the influence of this particular factor from other program elements. Second, men exhibit higher non-farm baseline employment than women (49 percent compared to 18 percent for women) and therefore it is easier for women to make larger gains on the extensive margin. Third, women face higher labor market barriers as compared to men. We investigate this third potential explanation in Table 6, where we examine time allocation decisions by men and women for paid versus unpaid work, inside and outside the household, more closely. The results in Table 6 present a compelling story: program impacts on employment seem to be strongly driven by women who start self-employment activities inside the house, whereas unpaid work inside the house, and activities outside the house, remain unaffected by the program. These results suggest that the program is particularly effective at placing women into income generating activities while they remain at home - in this way, they conform to Nepal's social norms that restrict female mobility and bind them to household responsibilities.

\subsection{Trade-wise program effects}

We examine program effects by type of trade and we classify training courses into nine categories. The most common training categories are: Tailoring/Garment/Textile (e.g., galaicha weaving, garment fabrication, hand embroidery, tailoring and dressmaking), Construction/Mechanical/ Automobile (e.g., arc welding, brick molding, furniture making, motor bike service), and Electrical/Electronics/Computer (e.g., electric wiring,

\footnotetext{
33 Acevedo et al. (2017), Adhvaryu et al. (2016), Bandiera et al. (2017), Ibarraran et al. (2014), and Martinez (2011) show significant impacts of life-skills interventions on labor market or productivity outcomes; Groh et al. (2012) find significant impacts of life-skills training intervention on women outside Jordan's capital; Ashraf et al. (2017) find significant impacts of a life-skills intervention among adolescent girls on subsequent human capital investment decisions in Zambia. In the Dominican Republic, Acevedo et al. (2017) examine the effectiveness of a life-skills intervention for men and women and, in fact, find higher effect sizes of the intervention on women. Adhvaryu et al. (2016), Bandiera et al. (2017), AGI (2013), USAID (2015), and Katz (2008) provide arguments for inclusion of life-skills (either alone or bundled with vocational training) targeting women in developing countries.
} 


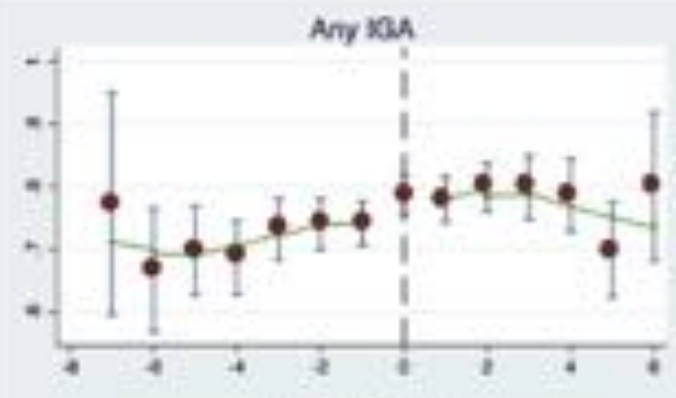

Relative Soore Any Nostam Whate-employed IOA

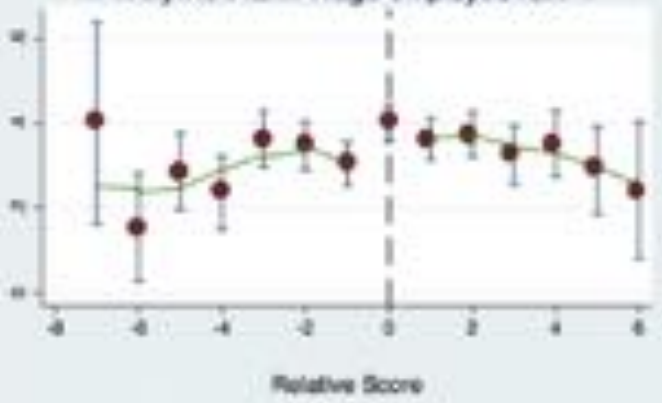

keA Seme Category as Training
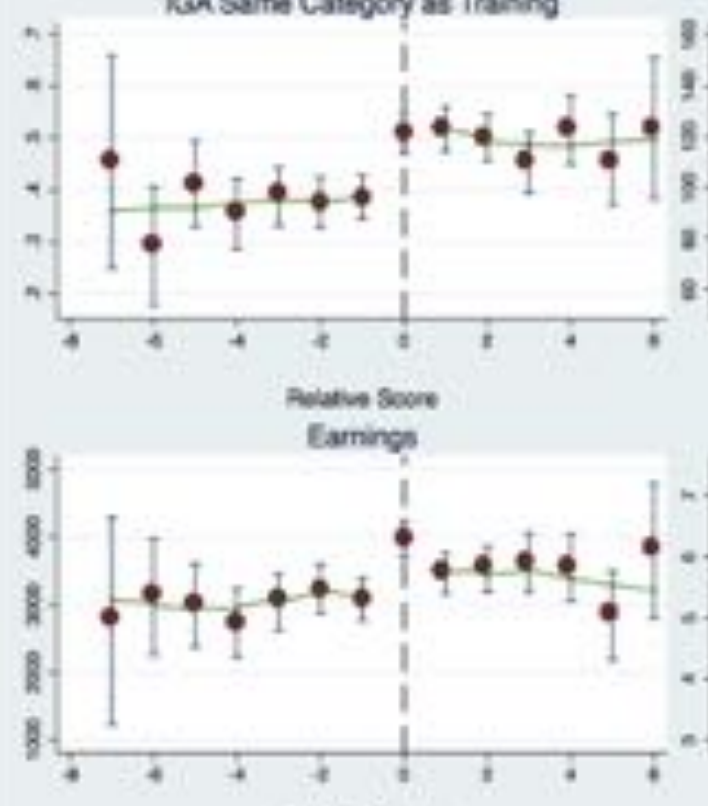

Relative Soove

Eamingas $>3000 \mathrm{NPs}$

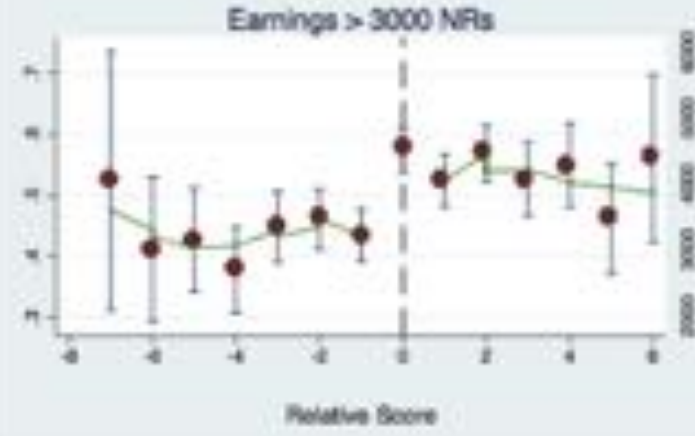

Any Non-larm iaA
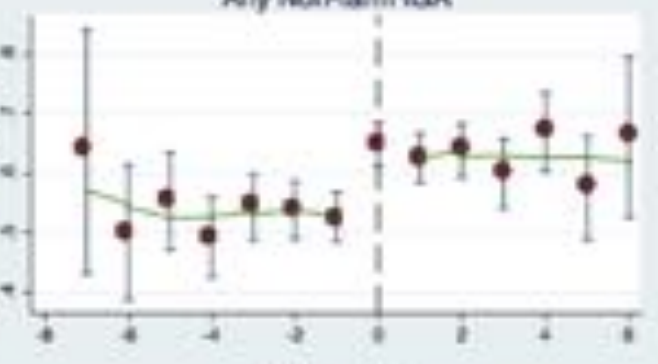

Rolave Soore

Any Non-farm Bet-employed IOA

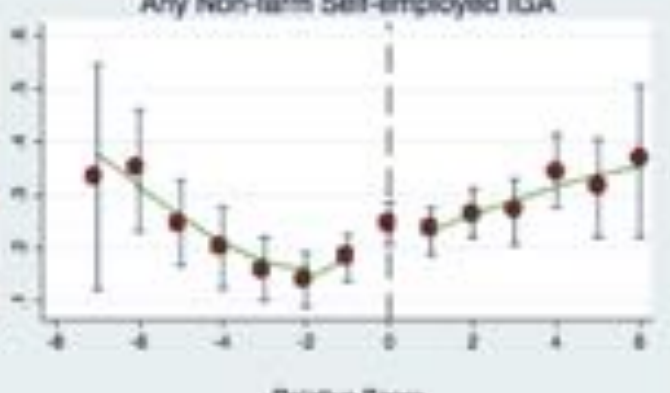

Relave Boore

Montly Hours

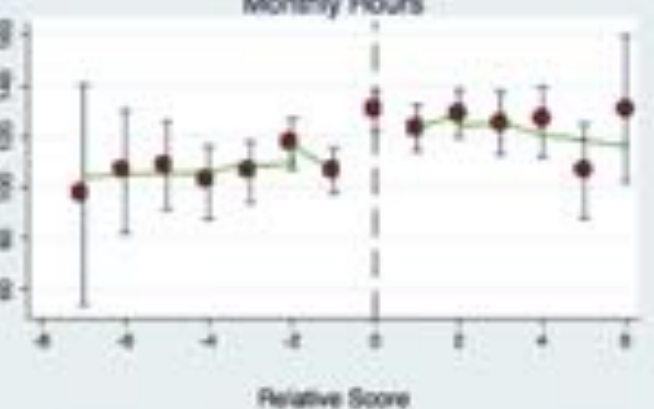

Log Eaming:

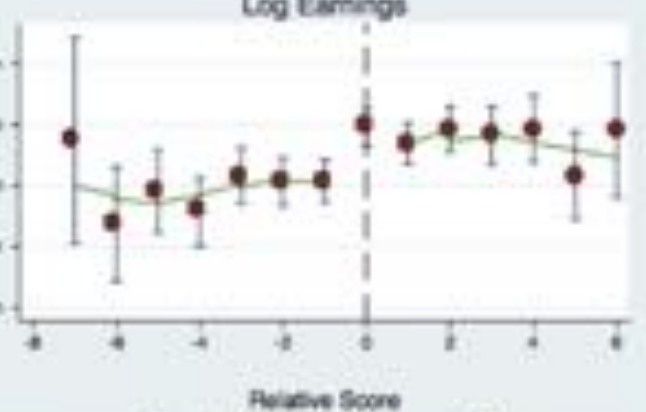

Eamings, Cond on Ary IGA

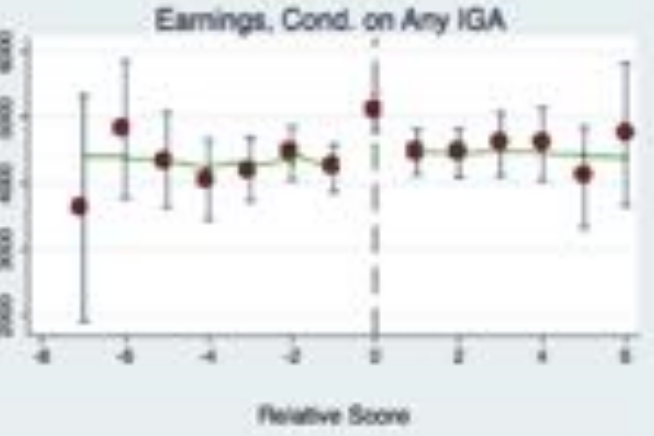

Fig. 8. Graphical representation of intent-to-treat results. 
Table 5

Employment by gender.

\begin{tabular}{|c|c|c|c|c|c|c|c|c|c|c|}
\hline & $\begin{array}{l}\text { Any IGA } \\
(1=\text { Yes })\end{array}$ & $\begin{array}{l}\text { Any non- } \\
\text { farm IGA } \\
(1=\text { Yes })\end{array}$ & $\begin{array}{l}\text { Non-farm } \\
\text { wage IGA } \\
(1=\text { Yes })\end{array}$ & $\begin{array}{l}\text { Non-farm } \\
\text { self IGA } \\
(1=\text { Yes })\end{array}$ & $\begin{array}{l}\text { Trade- } \\
\text { specific IGA } \\
(1=\text { Yes })\end{array}$ & $\begin{array}{l}\text { Hours } \\
\text { worked in } \\
\text { past month }\end{array}$ & Earnings & $\begin{array}{l}\text { Logged } \\
\text { earnings }\end{array}$ & $\begin{array}{l}\text { Earnings }>3000 \\
\text { NRs. }(1=\text { Yes })\end{array}$ & $\begin{array}{l}\text { Earnings, } \\
\text { conditional on } \\
\text { any IGA }\end{array}$ \\
\hline & (1) & (2) & (3) & (4) & (5) & (6) & (7) & $(8)$ & (9) & $(10)$ \\
\hline \multicolumn{11}{|c|}{ Panel A: HLATE, DD (Reconstructed Score) } \\
\hline Women & $\begin{array}{l}0.26^{*} \\
(0.14)\end{array}$ & $\begin{array}{l}0.53^{* * *} \\
(0.14)\end{array}$ & $\begin{array}{l}0.21 \\
(0.13)\end{array}$ & $\begin{array}{l}0.46^{* * *} \\
(0.15)\end{array}$ & $\begin{array}{l}0.54 * * * \\
(0.15)\end{array}$ & $\begin{array}{l}90.43^{* * *} \\
(24.67)\end{array}$ & $\begin{array}{l}2113^{* * *} \\
(784)\end{array}$ & $\begin{array}{l}3.51 * * * \\
(1.11)\end{array}$ & $\begin{array}{l}0.52^{* * *} \\
(0.13)\end{array}$ & $\begin{array}{l}1590 \\
(1256)\end{array}$ \\
\hline Men & $\begin{array}{l}-0.09 \\
(0.12)\end{array}$ & $\begin{array}{l}-0.04 \\
(0.15)\end{array}$ & $\begin{array}{l}-0.11 \\
(0.17)\end{array}$ & $\begin{array}{l}0.03 \\
(0.13)\end{array}$ & $\begin{array}{l}0.18 \\
(0.16)\end{array}$ & $\begin{array}{l}-18.63 \\
(27.33)\end{array}$ & $\begin{array}{l}977 \\
(1028)\end{array}$ & $\begin{array}{l}-1.20 \\
(1.10)\end{array}$ & $\begin{array}{l}-0.04 \\
(0.14)\end{array}$ & $\begin{array}{l}2461 * \\
(1470)\end{array}$ \\
\hline Difference & $\begin{array}{l}0.35^{* *} \\
(0.16)\end{array}$ & $\begin{array}{l}0.56 * * * \\
(0.19)\end{array}$ & $\begin{array}{l}0.32 * \\
(0.18)\end{array}$ & $\begin{array}{l}0.43^{* *} \\
(0.17)\end{array}$ & $\begin{array}{l}0.36^{*} \\
(0.20)\end{array}$ & $\begin{array}{l}109.1 * * * \\
(30.65)\end{array}$ & $\begin{array}{l}1136 \\
(1143)\end{array}$ & $\begin{array}{l}4.71 * * * \\
(1.40)\end{array}$ & $\begin{array}{l}0.56 * * * \\
(0.17)\end{array}$ & $\begin{array}{l}-871 \\
(1560)\end{array}$ \\
\hline Bandwidth & 12 & 12 & 12 & 11 & 12 & 12 & 9 & 12 & 12 & 12 \\
\hline Observations & 4004 & 4004 & 2608 & 2606 & 4004 & 4004 & 3822 & 3838 & 3838 & 1931 \\
\hline \multicolumn{11}{|c|}{ Group means at Baseline (Within a given Bandwidth) } \\
\hline Women & 0.52 & 0.19 & 0.07 & 0.10 & 0.11 & 46.94 & 770 & 2.43 & 0.10 & 1492 \\
\hline Men & 0.77 & 0.47 & 0.38 & 0.09 & 0.29 & 106.90 & 2130 & 4.77 & 0.34 & 2778 \\
\hline \multicolumn{11}{|c|}{ Panel B: Heterogeneous ITT, DD (Reconstructed Score) } \\
\hline Women & $\begin{array}{l}0.08^{*} \\
(0.04)\end{array}$ & $\begin{array}{l}0.16^{* * *} \\
(0.04)\end{array}$ & $\begin{array}{l}0.07^{*} \\
(0.04)\end{array}$ & $\begin{array}{l}0.14 * * * \\
(0.04)\end{array}$ & $\begin{array}{l}0.16 * * * \\
(0.05)\end{array}$ & $\begin{array}{l}27.15^{* * *} \\
(7.01)\end{array}$ & $\begin{array}{l}659 * * * \\
(242)\end{array}$ & $\begin{array}{l}1.06 * * * \\
(0.33)\end{array}$ & $\begin{array}{l}0.16^{* * *} \\
(0.04)\end{array}$ & $\begin{array}{l}488 \\
(381)\end{array}$ \\
\hline Men & $\begin{array}{l}-0.01 \\
(0.04)\end{array}$ & $\begin{array}{l}0.01 \\
(0.04)\end{array}$ & $\begin{array}{l}-0.02 \\
(0.04)\end{array}$ & $\begin{array}{l}0.02 \\
(0.04)\end{array}$ & $\begin{array}{l}0.07 \\
(0.05)\end{array}$ & $\begin{array}{l}-1.88 \\
(8.10)\end{array}$ & $\begin{array}{l}386 \\
(310)\end{array}$ & $\begin{array}{l}-0.20 \\
(0.32)\end{array}$ & $\begin{array}{l}0.01 \\
(0.04)\end{array}$ & $\begin{array}{l}698^{*} \\
(392)\end{array}$ \\
\hline Difference & $\begin{array}{l}0.09 * * \\
(0.04)\end{array}$ & $\begin{array}{l}0.15 * * * \\
(0.05)\end{array}$ & $\begin{array}{l}0.09^{*} \\
(0.05)\end{array}$ & $\begin{array}{l}0.12^{* *} \\
(0.05)\end{array}$ & $\begin{array}{l}0.09 \\
(0.06)\end{array}$ & $\begin{array}{l}29.03^{* * *} \\
(8.01)\end{array}$ & $\begin{array}{l}273 \\
(313)\end{array}$ & $\begin{array}{l}1.25 * * * \\
(0.37)\end{array}$ & $\begin{array}{l}0.15 * * * \\
(0.04)\end{array}$ & $\begin{array}{l}-210 \\
(420)\end{array}$ \\
\hline
\end{tabular}

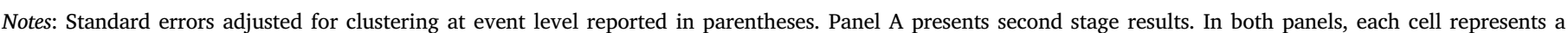

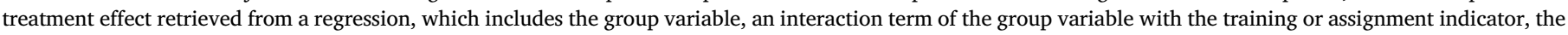

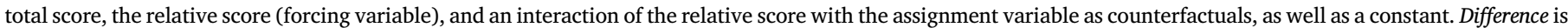

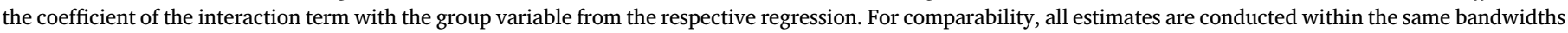

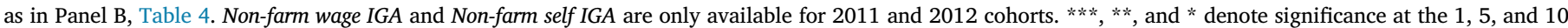
percent level.

computer hardware technician, and mobile phone repair). These are followed by trainings related to Food preparation/Hospitality skills, Beautician/Barber skills, and Handicraft/Incense making skills. Finally, a few events in our sample are related to Farming, Poultry, and Security Guard skills training. Table 7 shows the breakdown of courses by trade. Although the EF specifically tried to encourage female participation in non- traditionally female trades, most of the training courses tended to be heavily gender-segregated. For example, men tended to dominate electronics and construction courses, whereas the tailoring, handicraft, and beautician training sessions were almost exclusively comprised of women.

Table 8 examines program impacts for the six most common training categories. Due to the low number of courses and participants, we

Table 6

Time use by gender.

\begin{tabular}{|c|c|c|c|c|c|c|}
\hline & \multicolumn{6}{|l|}{ Hours/week working: } \\
\hline & \multirow{2}{*}{$\begin{array}{l}\text { Unpaid, inside house } \\
>5(1=\text { Yes }) \\
(1)\end{array}$} & \multirow{2}{*}{$\begin{array}{l}\text { Unpaid, inside } \\
\text { house }>10(1=\text { Yes }) \\
(2)\end{array}$} & \multirow{2}{*}{$\begin{array}{l}\text { Unpaid, inside } \\
\text { house }>20(1=\text { Yes }) \\
(3)\end{array}$} & \multirow{2}{*}{$\begin{array}{l}\text { Unpaid, outside } \\
\text { house }>0(1=\text { Yes }) \\
(4)\end{array}$} & \multirow{2}{*}{$\begin{array}{l}\text { Paid, inside house }>0 \\
\frac{(1=\text { Yes })}{(5)}\end{array}$} & \multirow{2}{*}{$\begin{array}{l}\text { Paid, outside house }>0 \\
(1=\text { Yes }) \\
(6)\end{array}$} \\
\hline & & & & & & \\
\hline \multicolumn{7}{|c|}{ Panel A: HLATE, DD (Reconstructed Score) } \\
\hline Women & $\begin{array}{l}-0.13 \\
(0.09)\end{array}$ & $\begin{array}{l}-0.12 \\
(0.12)\end{array}$ & $\begin{array}{l}0.10 \\
(0.22)\end{array}$ & $\begin{array}{l}0.03 \\
(0.16)\end{array}$ & $\begin{array}{l}0.42^{* * *} \\
(0.15)\end{array}$ & $\begin{array}{l}0.07 \\
(0.12)\end{array}$ \\
\hline Men & $\begin{array}{l}0.04 \\
(0.16)\end{array}$ & $\begin{array}{l}0.02 \\
(0.15)\end{array}$ & $\begin{array}{l}0.15 \\
(0.20)\end{array}$ & $\begin{array}{l}-0.11 \\
(0.17)\end{array}$ & $\begin{array}{l}0.08 \\
(0.17)\end{array}$ & $\begin{array}{l}-0.08 \\
(0.13)\end{array}$ \\
\hline Difference & $\begin{array}{l}-0.17 \\
(0.17)\end{array}$ & $\begin{array}{l}-0.14 \\
(0.17)\end{array}$ & $\begin{array}{l}-0.06 \\
(0.17)\end{array}$ & $\begin{array}{l}0.15 \\
(0.22)\end{array}$ & $\begin{array}{l}0.34 \\
(0.21)\end{array}$ & $\begin{array}{l}0.16 \\
(0.16)\end{array}$ \\
\hline Bandwidth & 12 & 12 & 2 & 12 & 12 & 12 \\
\hline Observations & 4003 & 4003 & 2133 & 4000 & 4004 & 4002 \\
\hline \multicolumn{7}{|c|}{ Group means at Baseline (Within a Given Bandwidth) } \\
\hline Women & 0.94 & 0.82 & 0.60 & 0.56 & 0.47 & 0.36 \\
\hline Men & 0.61 & 0.32 & 0.11 & 0.70 & 0.59 & 0.69 \\
\hline \multicolumn{7}{|c|}{ Panel B: Heterogeneous ITT, DD (Reconstructed Score) } \\
\hline Women & $\begin{array}{l}-0.04 \\
(0.03)\end{array}$ & $\begin{array}{l}-0.04 \\
(0.03)\end{array}$ & $\begin{array}{l}0.03 \\
(0.06)\end{array}$ & $\begin{array}{l}0.00 \\
(0.05)\end{array}$ & $\begin{array}{l}0.13^{* * *} \\
(0.04)\end{array}$ & $\begin{array}{l}0.02 \\
(0.03)\end{array}$ \\
\hline Men & $\begin{array}{l}0.01 \\
(0.05)\end{array}$ & $\begin{array}{l}-0.00 \\
(0.05)\end{array}$ & $\begin{array}{l}0.05 \\
(0.06)\end{array}$ & $\begin{array}{l}-0.03 \\
(0.05)\end{array}$ & $\begin{array}{l}0.04 \\
(0.05)\end{array}$ & $\begin{array}{l}-0.02 \\
(0.04)\end{array}$ \\
\hline Difference & $\begin{array}{l}-0.05 \\
(0.05)\end{array}$ & $\begin{array}{l}-0.04 \\
(0.05)\end{array}$ & $\begin{array}{l}-0.02 \\
(0.05)\end{array}$ & $\begin{array}{l}0.03 \\
(0.06)\end{array}$ & $\begin{array}{l}0.09 \\
(0.06)\end{array}$ & $\begin{array}{l}0.04 \\
(0.04)\end{array}$ \\
\hline
\end{tabular}

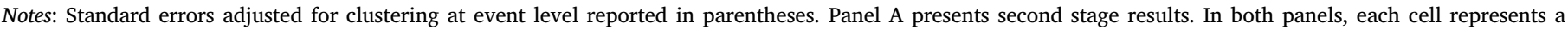

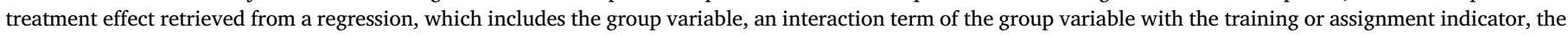

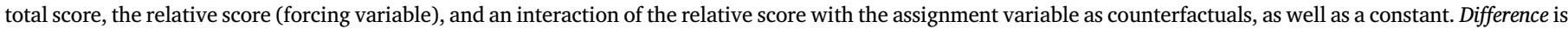
the coefficient of the interaction term with the group variable from the respective regression. ${ }^{* *}$, **, and * denote significance at the 1 , 5 , and 10 percent level. 
Table 7

Types of training.

\begin{tabular}{|c|c|c|c|c|c|}
\hline & \multicolumn{2}{|l|}{ By Event } & \multicolumn{2}{|c|}{ By Applicant } & \multirow{2}{*}{$\begin{array}{l}\text { Female } \\
\text { Applicants } \\
\text { Percent }\end{array}$} \\
\hline & Frequency & Percent & Frequency & Percent & \\
\hline Farming & 5 & 2 & 92 & 2 & 88 \\
\hline Poultry & 2 & 1 & 41 & 1 & 100 \\
\hline $\begin{array}{l}\text { Food Prep/ } \\
\text { Hospitality }\end{array}$ & 16 & 7 & 260 & 6 & 54 \\
\hline $\begin{array}{l}\text { Electrical/ } \\
\text { Electronics/ } \\
\text { Computer }\end{array}$ & 37 & 17 & 639 & 16 & 18 \\
\hline $\begin{array}{l}\text { Handicraft \& } \\
\text { Incense }\end{array}$ & 12 & 5 & 233 & 6 & 89 \\
\hline $\begin{array}{c}\text { Construction/ } \\
\text { Mechanical/ } \\
\text { Automobile }\end{array}$ & 63 & 29 & 1127 & 27 & 30 \\
\hline $\begin{array}{l}\text { Beautician/ } \\
\text { Barber }\end{array}$ & 11 & 5 & 239 & 6 & 100 \\
\hline $\begin{array}{l}\text { Tailoring/ } \\
\text { Garment/ } \\
\text { Textile }\end{array}$ & 72 & 33 & 1457 & 36 & 98 \\
\hline Security Guard & 1 & 0 & 13 & 0 & 100 \\
\hline Total & 219 & 100 & 4101 & 100 & \\
\hline
\end{tabular}

dropped the remaining three categories from the analysis. Table 8 shows that the impacts of the skills training program differed markedly by type of trade. Trainings in beautician and tailoring consistently show strong impacts on employment—graduates of these training programs are more likely to have any (non-farm) employment and are also more likely to be working within the trade for which they were trained. Both trades also show large impacts on monthly hours worked and some of the earnings indicators.

For the remaining four trades, we do not detect conclusive, and significant, positive impacts. The coefficients of the trainings related to food preparation and hospitality even seem to reflect some negative influence of training on labor market outcomes (although these coefficients are mostly insignificant). Overall, the results in Table 8 reveal substantial heterogeneity in employment and earning outcomes across the various types of training. The positive, and significant, impacts previously discussed are driven almost entirely by two categories of trades: beautician training and tailoring, both of which are almost entirely occupied by female trainees, which is in line with the large gender-differences in program impacts presented earlier.

\section{Robustness checks}

Next, we present a number of consistency checks to investigate whether our estimates are within a reasonable range. We also provide additional robustness checks to address possible identification threats related to attrition issues or specification choices.

Table 8

Employment by trade.

\begin{tabular}{|c|c|c|c|c|c|c|c|c|c|c|}
\hline & $\begin{array}{l}\text { Any IGA } \\
(1=\text { Yes })\end{array}$ & $\begin{array}{l}\text { Any non- } \\
\text { farm IGA } \\
(1=\text { Yes })\end{array}$ & $\begin{array}{l}\text { Non-farm } \\
\text { wage IGA } \\
(1=\text { Yes })\end{array}$ & $\begin{array}{l}\text { Non-farm } \\
\text { self IGA } \\
(1=\text { Yes })\end{array}$ & $\begin{array}{l}\text { Trade- } \\
\text { specific IGA } \\
(1=\text { Yes })\end{array}$ & $\begin{array}{l}\text { Hours } \\
\text { worked in } \\
\text { past month }\end{array}$ & Earnings & $\begin{array}{l}\text { Logged } \\
\text { earnings }\end{array}$ & $\begin{array}{l}\text { Earnings > } 3000 \\
\text { NRs. }(1=\text { Yes })\end{array}$ & $\begin{array}{l}\text { Earnings, } \\
\text { conditional on } \\
\text { any IGA }\end{array}$ \\
\hline & (1) & $(2)$ & (3) & (4) & (5) & (6) & (7) & $(8)$ & (9) & $(10)$ \\
\hline \multicolumn{11}{|c|}{ Panel A: HLATE, DD (Reconstructed Score) } \\
\hline $\begin{array}{l}\text { Food prep. \& } \\
\text { Hospitality }\end{array}$ & $\begin{array}{l}-0.34 \\
(0.43)\end{array}$ & $\begin{array}{l}-0.62 \\
(0.64)\end{array}$ & $\begin{array}{l}-1.73 \\
(1.14)\end{array}$ & $\begin{array}{l}1.64^{* * *} \\
(0.55)\end{array}$ & $\begin{array}{l}-0.73 \\
(0.69)\end{array}$ & $\begin{array}{l}-101.23 \\
(110.95)\end{array}$ & $\begin{array}{l}-5608 \\
(4626)\end{array}$ & $\begin{array}{l}-4.98 \\
(5.22)\end{array}$ & $\begin{array}{l}-0.43 \\
(0.56)\end{array}$ & $\begin{array}{l}-156 \\
(6068)\end{array}$ \\
\hline $\begin{array}{l}\text { Electrician \& } \\
\text { Electronics }\end{array}$ & $\begin{array}{l}-0.25 \\
(0.19)\end{array}$ & $\begin{array}{l}0.04 \\
(0.17)\end{array}$ & $\begin{array}{l}0.02 \\
(0.19)\end{array}$ & $\begin{array}{l}0.03 \\
(0.17)\end{array}$ & $\begin{array}{l}0.42^{* * *} \\
(0.16)\end{array}$ & $\begin{array}{l}-48.10 \\
(35.92)\end{array}$ & $\begin{array}{l}-172 \\
(1280)\end{array}$ & $\begin{array}{l}-1.53 \\
(1.39)\end{array}$ & $\begin{array}{l}-0.06 \\
(0.18)\end{array}$ & $\begin{array}{l}2028 \\
(1644)\end{array}$ \\
\hline $\begin{array}{l}\text { Handicraft \& } \\
\text { Incense stick } \\
\text { making }\end{array}$ & $\begin{array}{l}0.11 \\
(0.47)\end{array}$ & $\begin{array}{l}-0.58 \\
(0.57)\end{array}$ & $\begin{array}{l}-0.22 \\
(0.14)\end{array}$ & $\begin{array}{l}0.25 \\
(0.24)\end{array}$ & $\begin{array}{l}-1.02 \\
(0.80)\end{array}$ & $\begin{array}{l}51.40 \\
(56.27)\end{array}$ & $\begin{array}{l}1150 \\
(2666)\end{array}$ & $\begin{array}{l}-2.05 \\
(3.55)\end{array}$ & $\begin{array}{l}0.18 \\
(0.30)\end{array}$ & $\begin{array}{l}1715 \\
(2900)\end{array}$ \\
\hline $\begin{array}{l}\text { Construction \& } \\
\text { Mechanics }\end{array}$ & $\begin{array}{l}-0.08 \\
(0.11)\end{array}$ & $\begin{array}{l}-0.03 \\
(0.17)\end{array}$ & $\begin{array}{l}-0.01 \\
(0.21)\end{array}$ & $\begin{array}{l}-0.07 \\
(0.13)\end{array}$ & $\begin{array}{l}0.12 \\
(0.20)\end{array}$ & $\begin{array}{l}11.47 \\
(29.32)\end{array}$ & $\begin{array}{l}139 \\
(1139)\end{array}$ & $\begin{array}{l}-1.49 \\
(1.27)\end{array}$ & $\begin{array}{l}0.00 \\
(0.16)\end{array}$ & $\begin{array}{l}1716 \\
(1407)\end{array}$ \\
\hline $\begin{array}{l}\text { Beautician \& } \\
\text { Barber }\end{array}$ & $\begin{array}{l}1.08^{*} \\
(0.65)\end{array}$ & $\begin{array}{l}1.06^{*} \\
(0.54)\end{array}$ & $\begin{array}{l}0.67^{* *} \\
(0.29)\end{array}$ & $\begin{array}{l}0.34 \\
(0.29)\end{array}$ & $\begin{array}{l}0.99 * * * \\
(0.37)\end{array}$ & $\begin{array}{l}205.57^{* *} \\
(89.18)\end{array}$ & $\begin{array}{l}4379 \\
(2721)\end{array}$ & $\begin{array}{l}6.63^{*} \\
(3.62)\end{array}$ & $\begin{array}{l}0.56^{* *} \\
(0.27)\end{array}$ & $\begin{array}{l}-1391 \\
(4295)\end{array}$ \\
\hline $\begin{array}{l}\text { Weaving, } \\
\text { Tailoring \& } \\
\text { Garment } \\
\text { Making }\end{array}$ & $\begin{array}{l}0.38^{* *} \\
(0.18)\end{array}$ & $\begin{array}{l}0.82^{* * *} \\
(0.18)\end{array}$ & $\begin{array}{l}0.30 * \\
(0.18)\end{array}$ & $\begin{array}{l}0.57 * * * \\
(0.20)\end{array}$ & $\begin{array}{l}0.86 * * * \\
(0.20)\end{array}$ & $\begin{array}{l}112.5^{* * *} \\
(32.10)\end{array}$ & $\begin{array}{l}3572 * * * \\
(1127)\end{array}$ & $\begin{array}{l}5.70 * * * \\
(1.59)\end{array}$ & $\begin{array}{l}0.75^{* * *} \\
(0.19)\end{array}$ & $\begin{array}{l}2985^{*} \\
(1621)\end{array}$ \\
\hline \multicolumn{11}{|c|}{ Panel B: Heterogeneous ITT, DD (Reconstructed Score) } \\
\hline $\begin{array}{l}\text { Food prep. \& } \\
\text { Hospitality }\end{array}$ & $\begin{array}{l}-0.05 \\
(0.08)\end{array}$ & $\begin{array}{l}-0.09 \\
(0.10)\end{array}$ & $\begin{array}{l}-0.31^{* * *} \\
(0.09)\end{array}$ & $\begin{array}{l}0.31 \\
(0.20)\end{array}$ & $\begin{array}{l}-0.10 \\
(0.09)\end{array}$ & $\begin{array}{l}-14.68 \\
(18.02)\end{array}$ & $\begin{array}{l}-924 * \\
(545)\end{array}$ & $\begin{array}{l}-0.83 \\
(0.82)\end{array}$ & $\begin{array}{l}-0.06 \\
(0.09)\end{array}$ & $\begin{array}{l}-10 \\
(836)\end{array}$ \\
\hline $\begin{array}{l}\text { Electrician \& } \\
\text { Electronics }\end{array}$ & $\begin{array}{l}-0.08 \\
(0.06)\end{array}$ & $\begin{array}{l}0.02 \\
(0.06)\end{array}$ & $\begin{array}{l}0.01 \\
(0.06)\end{array}$ & $\begin{array}{l}0.01 \\
(0.05)\end{array}$ & $\begin{array}{l}0.15^{* *} \\
(0.06)\end{array}$ & $\begin{array}{l}-13.52 \\
(11.24)\end{array}$ & $\begin{array}{l}28 \\
(433)\end{array}$ & $\begin{array}{l}-0.42 \\
(0.44)\end{array}$ & $\begin{array}{l}-0.01 \\
(0.06)\end{array}$ & $\begin{array}{l}639 \\
(524)\end{array}$ \\
\hline $\begin{array}{l}\text { Handicraft \& } \\
\text { Incense stick } \\
\text { making }\end{array}$ & $\begin{array}{l}0.04 \\
(0.12)\end{array}$ & $\begin{array}{l}-0.12 \\
(0.11)\end{array}$ & $\begin{array}{l}-0.09 \\
(0.07)\end{array}$ & $\begin{array}{l}0.10 \\
(0.10)\end{array}$ & $\begin{array}{l}-0.22^{*} \\
(0.12)\end{array}$ & $\begin{array}{l}16.38 \\
(14.99)\end{array}$ & $\begin{array}{l}424 \\
(629)\end{array}$ & $\begin{array}{l}-0.34 \\
(0.77)\end{array}$ & $\begin{array}{l}0.07 \\
(0.07)\end{array}$ & $\begin{array}{l}675 \\
(1018)\end{array}$ \\
\hline $\begin{array}{c}\text { Construction \& } \\
\text { Mechanics }\end{array}$ & $\begin{array}{l}-0.02 \\
(0.04)\end{array}$ & $\begin{array}{l}0.01 \\
(0.05)\end{array}$ & $\begin{array}{l}0.00 \\
(0.05)\end{array}$ & $\begin{array}{l}0.00 \\
(0.03)\end{array}$ & $\begin{array}{l}0.06 \\
(0.06)\end{array}$ & $\begin{array}{l}6.56 \\
(9.25)\end{array}$ & $\begin{array}{l}526 \\
(347)\end{array}$ & $\begin{array}{l}-0.29 \\
(0.38)\end{array}$ & $\begin{array}{l}0.02 \\
(0.05)\end{array}$ & $\begin{array}{l}552 \\
(383)\end{array}$ \\
\hline $\begin{array}{l}\text { Beautician \& } \\
\text { Barber }\end{array}$ & $\begin{array}{l}0.25^{* *} \\
(0.11)\end{array}$ & $\begin{array}{l}0.26 * * * \\
(0.08)\end{array}$ & $\begin{array}{l}0.21 * * * \\
(0.07)\end{array}$ & $\begin{array}{l}0.11 \\
(0.09)\end{array}$ & $\begin{array}{l}0.25 * * * \\
(0.07)\end{array}$ & $\begin{array}{l}49.38^{* * * *} \\
(18.88)\end{array}$ & $\begin{array}{l}1096 * \\
(600)\end{array}$ & $\begin{array}{l}1.62^{* *} \\
(0.77)\end{array}$ & $\begin{array}{l}0.15^{* *} \\
(0.06)\end{array}$ & $\begin{array}{l}-366 \\
(1165)\end{array}$ \\
\hline $\begin{array}{l}\text { Weaving, } \\
\text { Tailoring \& } \\
\text { Garment } \\
\text { Making }\end{array}$ & $\begin{array}{l}0.11 * * \\
(0.05)\end{array}$ & $\begin{array}{l}0.24 * * * \\
(0.04)\end{array}$ & $\begin{array}{l}0.09 * \\
(0.05)\end{array}$ & $\begin{array}{l}0.16^{* * *} \\
(0.05)\end{array}$ & $\begin{array}{l}0.25^{* * *} \\
(0.05)\end{array}$ & $\begin{array}{l}32.32 * * * \\
(8.09)\end{array}$ & $\begin{array}{l}1043^{* * * *} \\
(304)\end{array}$ & $\begin{array}{l}1.64 * * * \\
(0.39)\end{array}$ & $\begin{array}{l}0.22^{* * *} \\
(0.05)\end{array}$ & $\begin{array}{l}985^{*} \\
(509)\end{array}$ \\
\hline
\end{tabular}

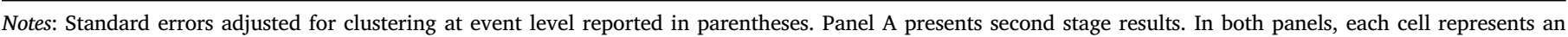

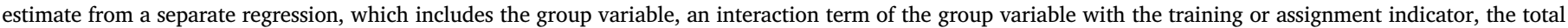

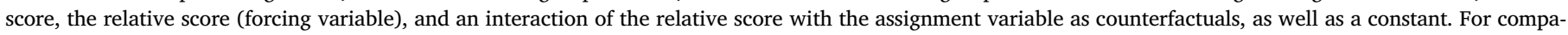

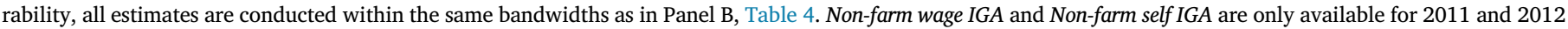
cohorts. $* * *, * *$, and $*$ denote significance at the 1,5 , and 10 percent level. 
Table 9

Employment, second follow-up (2010 cohort).

\begin{tabular}{|c|c|c|c|c|c|c|c|c|}
\hline & $\begin{array}{l}\text { Any IGA } \\
(1=\text { Yes })\end{array}$ & $\begin{array}{l}\text { Any non-farm IGA } \\
(1=\text { Yes })\end{array}$ & $\begin{array}{l}\text { Trade-specific IGA } \\
(1=\text { Yes })\end{array}$ & $\begin{array}{l}\text { Hours worked in } \\
\text { past month }\end{array}$ & Earnings & $\begin{array}{l}\text { Logged } \\
\text { earnings }\end{array}$ & $\begin{array}{l}\text { Earnings > } 3000 \text { NRs. } \\
(1=\text { Yes })\end{array}$ & $\begin{array}{l}\text { Earnings, conditional } \\
\text { on any IGA }\end{array}$ \\
\hline & (1) & (2) & (3) & (4) & (5) & (6) & (7) & (8) \\
\hline \multicolumn{9}{|l|}{ Panel A } \\
\hline LATE, DD & 0.06 & $0.40^{* * *}$ & $0.33^{* *}$ & 53.16 & 1277 & 0.65 & $0.40^{*}$ & 903 \\
\hline (Reconstr. Sc.) & $(0.17)$ & $(0.19)$ & $(0.16)$ & $(32.90)$ & (1362) & $(1.52)$ & $(0.23)$ & (1510) \\
\hline \multirow[t]{2}{*}{ First Stage } & $0.41^{* * *}$ & $0.41^{* * *}$ & $0.41^{* * *}$ & $0.41^{* * *}$ & $0.41^{* * *}$ & $0.41^{* * *}$ & $0.41^{* * *}$ & $0.47^{* * *}$ \\
\hline & $(0.06)$ & $(0.06)$ & $(0.06)$ & $(0.06)$ & $(0.06)$ & $(0.06)$ & $(0.06)$ & $(0.08)$ \\
\hline F-statistic & 48.33 & 48.33 & 48.33 & 48.33 & 42.58 & 42.58 & 42.58 & 36.07 \\
\hline $\begin{array}{l}\text { Baseline } \\
\text { mean }\end{array}$ & 0.61 & 0.31 & 0.18 & 81.37 & 1388 & 3.63 & 0.20 & 2304 \\
\hline Bandwidth & 10 & 10 & 10 & 10 & 10 & 10 & 10 & 10 \\
\hline Observations & 621 & 621 & 621 & 621 & 590 & 590 & 590 & 336 \\
\hline \multicolumn{9}{|l|}{ Panel B } \\
\hline ITT, DD & 0.01 & $0.16^{*}$ & $0.14 * *$ & 20.60 & 459 & 0.19 & $0.16^{*}$ & 349 \\
\hline (Reconst. Sc.) & $(0.07)$ & $(0.08)$ & $(0.07)$ & (14.33) & $(570)$ & $(0.65)$ & $(0.09)$ & $(726)$ \\
\hline \multicolumn{9}{|c|}{ Panel C: HLATE, DD (Reconstructed Score) } \\
\hline \multirow[t]{2}{*}{ Women } & -0.01 & 0.30 & 0.18 & 32.57 & 1630 & 1.12 & 0.38 & 1220 \\
\hline & $(0.26)$ & $(0.25)$ & $(0.23)$ & $(38.49)$ & $(1604)$ & $(2.05)$ & $(0.27)$ & $(1680)$ \\
\hline \multirow[t]{2}{*}{ Men } & 0.13 & $0.50 *$ & $0.48^{*}$ & 76.71 & 1087 & 0.13 & 0.43 & 425 \\
\hline & $(0.21)$ & $(0.28)$ & $(0.26)$ & $(58.26)$ & (1957) & $(2.48)$ & $(0.35)$ & $(2318)$ \\
\hline \multirow[t]{2}{*}{ Difference } & -0.14 & -0.20 & -0.29 & -44.15 & 542 & 0.99 & -0.05 & 795 \\
\hline & $(0.32)$ & $(0.36)$ & $(0.37)$ & (73.76) & $(2408)$ & $(3.38)$ & $(0.42)$ & (2578) \\
\hline Bandwidth & 10 & 10 & 10 & 10 & 10 & 10 & 10 & 10 \\
\hline Observations & 621 & 621 & 621 & 621 & 590 & 590 & 590 & 336 \\
\hline \multicolumn{9}{|c|}{ Group means at Baseline (Within a Given Bandwidth) } \\
\hline Women & 0.54 & 0.22 & 0.13 & 60.18 & 943 & 2.92 & 0.12 & 1736 \\
\hline Men & 0.70 & 0.45 & 0.26 & 113.65 & 2074 & 4.73 & 0.33 & 2987 \\
\hline \multicolumn{9}{|c|}{ Panel D: Heterogeneous ITT, DD (Reconstructed Score) } \\
\hline \multirow[t]{2}{*}{ Women } & -0.01 & 0.13 & 0.10 & 15.51 & 624 & 0.33 & 0.16 & 593 \\
\hline & $(0.09)$ & $(0.09)$ & $(0.08)$ & (14.54) & $(623)$ & $(0.77)$ & $(0.10)$ & $(871)$ \\
\hline \multirow[t]{2}{*}{ Men } & 0.04 & $0.19 *$ & $0.18 * *$ & 28.63 & 350 & 0.03 & 0.15 & 157 \\
\hline & $(0.07)$ & $(0.10)$ & $(0.09)$ & (21.19) & (658) & $(0.83)$ & $(0.12)$ & (781) \\
\hline \multirow[t]{2}{*}{ Difference } & -0.05 & -0.06 & -0.08 & -13.12 & 274 & 0.30 & 0.01 & 436 \\
\hline & $(0.09)$ & $(0.11)$ & $(0.11)$ & (20.81) & $(672)$ & $(0.96)$ & $(0.12)$ & (854) \\
\hline
\end{tabular}

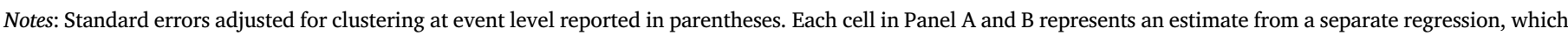

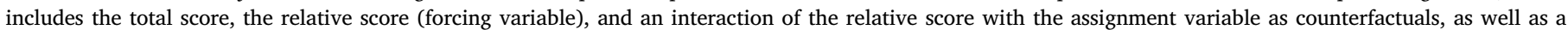

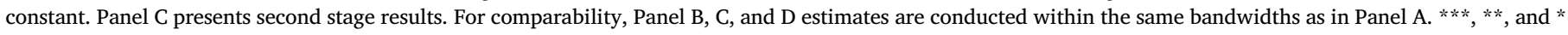
denote significance at the 1,5 , and 10 percent level.

Table 10

Time use by gender, second follow-up (2010 COHORT).

\begin{tabular}{|c|c|c|c|c|c|c|}
\hline & \multicolumn{6}{|l|}{ Hours/week working: } \\
\hline & \multirow{2}{*}{$\begin{array}{l}\text { Unpaid, inside } \\
\text { house }>5(1=\text { Yes }) \\
(1)\end{array}$} & \multirow{2}{*}{$\begin{array}{l}\text { Unpaid, inside } \\
\text { house }>10(1=\text { Yes }) \\
(2)\end{array}$} & \multirow{2}{*}{$\begin{array}{l}\text { Unpaid, inside } \\
\text { house }>20(1=\text { Yes }) \\
(3)\end{array}$} & \multirow{2}{*}{$\begin{array}{l}\text { Unpaid, outside } \\
\text { house > } 0(1=\text { Yes }) \\
(4)\end{array}$} & \multirow{2}{*}{$\begin{array}{l}\text { Paid, inside house }>0 \\
\frac{(1=\text { Yes })}{(5)}\end{array}$} & \multirow{2}{*}{$\begin{array}{l}\text { Paid, outside house }>0 \\
(1=\text { Yes }) \\
(6)\end{array}$} \\
\hline & & & & & & \\
\hline \multicolumn{7}{|c|}{ Panel A: HLATE, DD (Reconstructed Score) } \\
\hline \multirow[t]{2}{*}{ Women } & 0.20 & 0.32 & 0.30 & 0.43 & 0.26 & -0.09 \\
\hline & $(0.23)$ & $(0.25)$ & $(0.32)$ & $(0.32)$ & $(0.26)$ & $(0.35)$ \\
\hline \multirow[t]{2}{*}{ Men } & -0.24 & 0.23 & 0.26 & -0.09 & 0.13 & 0.22 \\
\hline & $(0.24)$ & $(0.26)$ & $(0.21)$ & $(0.28)$ & $(0.27)$ & $(0.28)$ \\
\hline \multirow[t]{2}{*}{ Difference } & 0.44 & 0.10 & 0.04 & 0.53 & 0.13 & -0.31 \\
\hline & $(0.37)$ & $(0.34)$ & $(0.35)$ & $(0.43)$ & $(0.33)$ & $(0.41)$ \\
\hline Bandwidth & 10 & 10 & 10 & 10 & 10 & 9 \\
\hline Observations & 620 & 620 & 620 & 620 & 621 & 621 \\
\hline \multicolumn{7}{|c|}{ Group means at Baseline (Within a Given Bandwidth) } \\
\hline Women & 0.95 & 0.82 & 0.54 & 0.55 & 0.41 & 0.43 \\
\hline Men & 0.65 & 0.36 & 0.14 & 0.65 & 0.48 & 0.67 \\
\hline \multicolumn{7}{|c|}{ Panel B: Heterogeneous ITT, DD (Reconstructed Score) } \\
\hline \multirow[t]{2}{*}{ Women } & 0.06 & 0.13 & 0.12 & 0.15 & 0.09 & -0.02 \\
\hline & $(0.08)$ & $(0.09)$ & $(0.12)$ & $(0.11)$ & $(0.11)$ & $(0.13)$ \\
\hline \multirow[t]{2}{*}{ Men } & -0.09 & 0.09 & 0.10 & -0.01 & 0.07 & 0.07 \\
\hline & $(0.09)$ & $(0.09)$ & $(0.08)$ & $(0.10)$ & $(0.10)$ & $(0.10)$ \\
\hline \multirow[t]{2}{*}{ Difference } & 0.15 & 0.04 & 0.03 & 0.15 & 0.03 & -0.09 \\
\hline & $(0.11)$ & $(0.10)$ & $(0.11)$ & $(0.12)$ & $(0.10)$ & $(0.12)$ \\
\hline
\end{tabular}

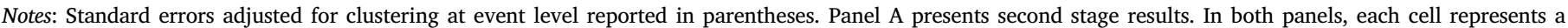

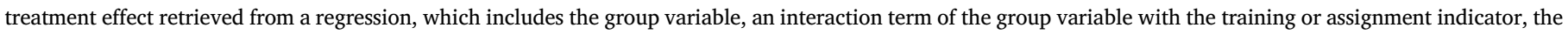

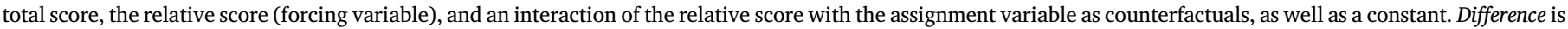
the coefficient of the interaction term with the group variable from the respective regression. ***,**, and * denote significance at the 1,5 , and 10 percent level. 
Table 11

Survey and administrative data comparision.

\begin{tabular}{|c|c|c|c|c|c|}
\hline & EF Verification Data & EF Verification Data & Survey Data & EF Verification Data & Survey Data \\
\hline $\begin{array}{l}\text { Months After Training } \\
2010\end{array}$ & 3 & 6 & 9-11 & 15 & $21-23$ \\
\hline $\begin{array}{l}\text { IGA with Earnings }>3000 \text { NRs. }(1=\text { Yes }) \\
2011\end{array}$ & $79 \%{ }^{\mathrm{a}}$ & - & $62 \%$ & - & $57 \%$ \\
\hline Any IGA $(1=$ Yes $)$ & - & - & $83 \%$ & $72 \%{ }^{\mathrm{d}}$ & - \\
\hline $\begin{array}{l}\text { IGA with Earnings }>3000 \text { NRs. }(1=\text { Yes }) \\
2012\end{array}$ & - & $80 \%^{\mathrm{b}}$ & $57 \%$ & - & - \\
\hline Any IGA $(1=$ Yes $)$ & - & $91 \%^{\mathrm{c}}$ & $73 \%$ & - & - \\
\hline IGA with Earnings $>3000$ NRs. $(1=$ Yes $)$ & - & $81 \%^{\mathrm{c}}$ & $60 \%$ & - & - \\
\hline IGA with Earnings $>4600$ NRs. $(1=$ Yes $)$ & - & $67 \%^{\mathrm{c}}$ & $46 \%$ & - & - \\
\hline
\end{tabular}

Sources.

a EF Annual Report 2010, p2.

b EF Annual Report 2011, p5.

c EF Annual Report 2012, p4.

d EF Tracer Study 2013, p23.

\subsection{Magnitude of program impacts}

Second Follow-up. Most of the employment results we find are driven by self-employment activities and, hence, they do not seem to be a direct effect of the job-search-assistance component of the program. Still, providers could eagerly support trainees even in their entrepreneurial efforts in order to secure the last two installments of the EF payments. The EF verified placement 3 and 6 months upon training completion and released the final payment installment to providers, if and only if, they verified that trainees were in fact engaged in gainful employment. Therefore, it is possible that the employment effects we detect 9-11 months upon completion of training might be a mechanical effect of the program design. To examine this hypothesis, we investigate data on a sub-sample of training applicants, for whom a second follow-up survey (21-23 months after end of the training) was collected. Approximately half of the applicants from the 2010 cohort were randomly selected to participate in this second follow-up survey. The survey team tracked and re-interviewed 634 individuals (79.5 percent) who were also interviewed at baseline. Using data from the follow up survey, we re-run the specifications from Table 4, Panel B and D, as well as the ones presented Tables 5 and 6 on medium-term outcomes. Tables 9 and 10 present the results.

We find that most of the main effect estimates, presented in Table 9's Panel A and B, are in the range of the estimates we found using the first follow-up data for the pooled sample. Strikingly, some of the estimates are slightly larger. In particular, we find statistically significant estimates for non-farm employment, trade-specific employment, and gainful employment rates of 40,33 , and 40 percentage points, respectively, for the compliers (LATE) as well as 16, 14, and 16 percentage points, respectively, for the individuals assigned to training based on the intentto-treat approach (ITT). Because the 2010 data do not include information on whether non-farm employment is based on wage- or selfemployment, we cannot make inferences on what drives the results in that dimension. However, when we investigate the medium-term disaggregated effects for the 2010 cohort, we find a slightly different pattern in comparison to the pattern based on the short-term impacts for the pooled sample. Although the coefficients for females are still positive, slightly lower in magnitude, and insignificant (possibly a result of reduced statistical power), we now find positive employment effects for men. Specifically, the non-farm and trade-specific employment rates for male compliers rise by 50 and 48 percentage points, respectively, while the medium-term male ITT effects show an increase of 19 and 18 percentage points, respectively.

Program impacts on time-use (reported in Table 10) show negative but insignificant coefficient estimates for female paid work outside the house and positive but insignificant coefficients for women who perform

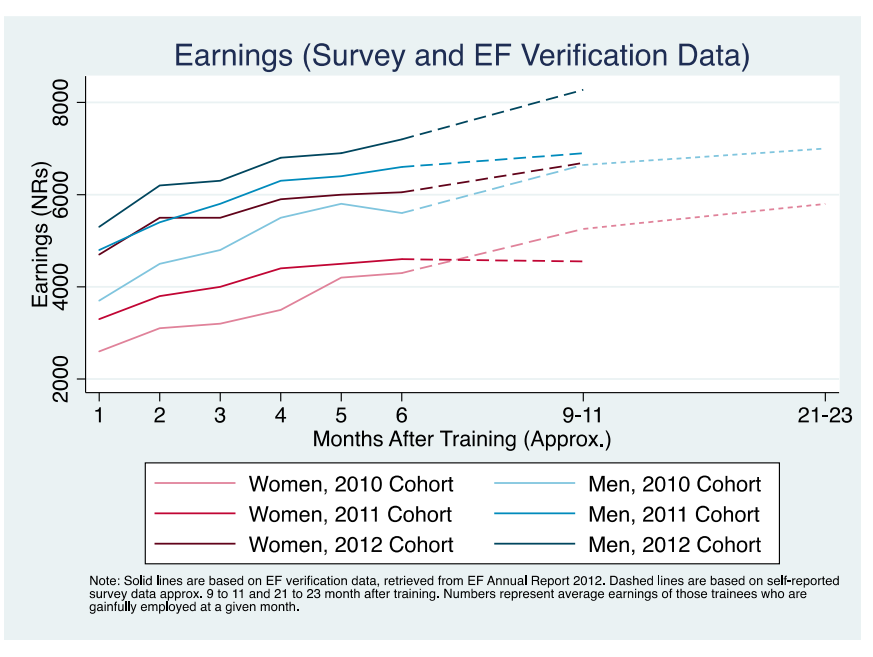

Fig. 9. Earnings based on survey and administrative data comparision.

paid work inside the house. For men, the coefficient estimates of both paid work inside and outside the house are positive but statistically insignificant. Although we do not detect statistically significant results, one could cautiously interpret them as somewhat suggestive evidence that medium-run employment rates for women, and to some extent for men, are also driven by self-employment activities.

EF Verification Data. For verification and monitoring purposes of program outcomes, the EF collected information on trainees' labor market outcomes. We retrieved information on these outcomes in aggregated form from four reports published by the EF from 2011 to $2013 .{ }^{34}$ As another robustness check of our results, we compare these aggregated employment and earnings data from the EF with the data from our surveys (reported in Table 11).

Based on the aggregated data, the share of trainees employed was 91 percent, six months after training completion, for the 2012 graduates. The share of trainees in gainful employment (i.e., monthly income $>3000 \mathrm{NRs}$ ) three and six months after completion of training was between 79 and 81 percent for the three cohorts. The employment rates, on the other hand, based on the self-reported data from our survey, range from 57 to 62 percent (9-11 months and 21-23 months after training completion). This comparison suggests that the numbers, based on the

\footnotetext{
34 Data is available from the Employment Fund Annual Reports 2010 to 2012 as well as a tracer study of $2011 \mathrm{EF}$ graduates, retrieved from http://www. employmentfund.org.np/category/resources/reports/ on Feb 24, 2018.
} 
self-reported survey, are generally lower than those reported in the EFverified data, which is consistent with the fact that providers receive their full payment after the six-month verification and that they have no additional incentives to support the job search of trainees. The rates for gainful employment are still relatively high among successful trainees at the time of our first and second follow-ups. Given that the employment rates at the three- and six-month mark are much higher, our estimates seem within a reasonable range.

In Fig. 9, we also compare the earnings numbers based on the EFverified data with the information from our first and second follow-up surveys. Given the growth trajectory of gainfully employed trainees' earnings over the first six months, post-training, the data based on the self-reported surveys seems reasonable and consistent with the overall pattern of the growth in earnings. Based both on this robustness check and also on the results from the 2010 cohort's second follow-up, we provide additional evidence consistent with the notion that our estimates are plausible.

\subsection{Differential attrition}

As in all panel studies, our estimates could be affected by a group-wise differential attrition. For instance, if trainees who are not admitted to the course choose to migrate for work abroad and if these are the most able and employable candidates of the control group, we would have an upward bias in our estimates. Therefore, in Table A4 of Appendix A, we explore the possibility of "differential attrition" and show no evidence to support it. Table A4 shows the results of a panel-based regression with attrition status as a dependent variable on a set of covariates for both the first follow-up (Columns 1 to 4 ) and the second-follow-up (Columns 5 to 8). All models are estimated based on the reconstructed score. In order to avoid the dropping of observations due to missing values in the control variables, Columns (3), (4), (7), and (8) include indicators that respectively flag missing values for each of the control variables. The regression results indicate that attrition is not correlated with assignment status in either wave.

\subsection{Alternative bandwidths}

To investigate the robustness of our results relative to bandwidth choice, we re-estimate our main specifications using bandwidths within $2,3,4,5$, and 10 index scores of the threshold based on the reconstructed score. Table A5 presents the results, showing that overall our estimates are relatively stable both in statistical significance and in coefficient magnitude. For most outcomes, the magnitudes of the effect sizes increase with lower bandwidth choice. Only for non-farm self-employment are the effect sizes reduced by a half in the full sample. However, the effects for the female sub-sample are still large, positive, and significant using a bandwidth of 3 (ITT: 11, LATE: 36 percentage points, not shown in table) and, although still similar in size, they become insignificant at a bandwidth of 2 (ITT: 9, LATE: 32 percentage points, not shown in table).

\subsection{Propensity score approach}

As a robustness check for estimates of program impact, we also employ a combination of differences-in-differences and a propensity score matching technique (Meyer, 1995). This approach, in the context of training programs, has the potential to purge possible differences between observable characteristics for trainees and non-trainees following
Dehejia and Wahba (2002). The results based on this approach are presented in Appendix B, and they essentially confirm the pattern of the analysis using the regression discontinuity setup in the main paper.

\section{Discussion and conclusion}

Training interventions have been hailed as one potential solution to facilitate youth transition to productive employment and higher earnings worldwide. Although previous evaluations of training programs, based on observational designs, typically show positive and statistically significant impacts of training on the probability of having a job and on labor market earnings, recent experimental interventions from middle- and high-income countries find little or no impact on employment and modest gains in earnings. Using a regression discontinuity design in the context of a large vocational training program in Nepal, we find very large positive and statistically significant effects from the training program on female employment, hours worked, and earnings. These effects, in particular, are driven by women who engage in non-farm self-employment activities carried out inside (but not outside) the house.

In line with the few other existing studies on similar programs in lowincome countries, our estimates of the employment effects of this training intervention are among the largest for training programs around the world. Features of the low-income background, the South Asian context, and the specific training intervention likely account for the large program impacts that we find. First, our program impacts are likely driven by a lack of alternative employment, skill training opportunities, and by extremely low education levels. Both of these phenomena are much more pronounced in the context of Nepal when compared with the context of the most recent experimental interventions from middle-income countries (i.e., in Latin America), especially so for women.

A second explanation behind the large program impacts relates to the extremely restrictive social norms regarding female labor force participation in Nepal. We find large program impacts on self-employment, especially inside the home, and these program effects are likely driven by social norms that prevent women from otherwise being active in the labor market. Restrictive norms regarding women entering the labor force exist in many regions of the world, but they seem to be particularly strong and restrictive for women in South Asia (World Bank, 2011; Asian Development Bank, 2015; Booth, 2016). Largely influenced by the Hindu philosophy on women's positions in society, Nepalese women face gender-based employment barriers due to restricted mobility, cultural norms, and societal norms as a result of gender expectations for certain occupations.

Finally, the EF training program was designed around employment outcomes such that training providers had to complete market assessments to ensure future employability with respect to the individually assigned trades. The training program was also bundled along with services, such as job placement, life-skills training, and business training, all of which likely also contributed to its effectiveness. Perhaps, most importantly, the program was directly tailored to the needs of the target population, and training providers were incentivized and closely monitored to accomplish their output.

Our results have important implications for the design and implementation of future training interventions in low-income countries. The empirical analysis presented here suggests important lessons for the successful modeling of effective labor market interventions where youth and female unemployment is a challenge. 


\section{Appendix}

A. Reconstruction of assignment score and threshold

\section{Application Form}

\begin{tabular}{l} 
Registration \#: \\
Personal Details \\
Name and Surname: \\
Sex: $\square$ Female $\square$ Male $\square$ other \\
Marital Status: $\square$ single \\
Date of Birth (Day/Month/Year): \\
Caste/Ethnicity: $\square$ Dalit \\
Special circumstances: $\square$ HIV-infected \\
\hline \multicolumn{1}{|c|}{ Permanent Address } \\
\hline District: \\
\hline Municipality/ VDC: \\
\hline Tole: \\
\hline Phone Number (Land line): \\
\hline Phone Number (Mobile): \\
\hline Father's Name: \\
\hline Mother's Name: \\
\hline Citizenship No.: \\
\hline Issued District: \\
\hline
\end{tabular}
nternally Displaced People

\section{Education Details}

Highest completed level of education:

$\square$ Illiterate $\square$ Below class $5 \quad \square$ Class 5-8 $\square$ Class 9-10 $\square$ sLC Pass $\square+2$

$\square$ Bachelor's degree and above

\begin{tabular}{|l|}
\hline \multicolumn{1}{|c|}{ Current Address } \\
\hline District: \\
\hline Municipality/ VDC: \\
\hline Tole: \\
\hline Phone Number (Land line): \\
\hline Phone Number (Mobile): \\
\hline
\end{tabular}

In case of getting information of you: Reference person:

Mobile Number:

If you have an academic certificate, please attoch a copy.

\section{Employment and Income Information}

What is your employment status and monthly earnings (own earnings only):

$\begin{array}{llll}\square \text { Self-employed } & \text { Monthly earnings:__ } & \square \text { Wage earner } & \text { Monthly earnings: } \\ \square \text { Agriculture } & \text { Monthly earnings:__ } & \square \text { Unemployed } & \text { Monthly earnings: } \\ \square \text { other } & \text { Monthly earnings:__ }\end{array}$

Estimated total monthly income Rs.

What is your family's average annual earnings in the following areas (excluding your own)?

$\square$ Labour Wages

Animal Husbandry $\square$ Salary

Foreign income
Stamp of the Training Institution

Age:

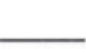


How many months can you feed your family through agricultural income from your own land?

$\square$ Less than 3 months $\square$ Less than 6 months $\square$ More than 6 months $\quad \square$ Do not have land

Training Information

Name of training:

District: V.D.C: Ward No: Start date:

Reason for interest in training:

$\square$ To start own work

$\square$ To upgrade skills

$\square$ To work for wages

$\square$ To go for foreign employment

How did you come to know about this training?

$\square$ Newspaper
$\square$ Poster
$\square$ Pamphlets
$\square$ FM radio

$\square$ Relatives/Friends

$\square$ Training Centre

$\square$ Local Development Agencies

Single Women Group

Have you had any previous training? $\square$ Yes $\square$ No

If yes, please provide the following information:

Name of Training:

Hours of Training:

Date completed:

I state that the above-mentioned details are true.

Signature of Applicant

Date (Day/Month/Year)

Fig. A1. (continued). 


\begin{tabular}{|c|c|c|c|c|c|c|c|c|c|c|c|c|}
\hline \multirow[b]{3}{*}{ \# } & \multirow[b]{3}{*}{ Name and Surname } & \multirow[b]{3}{*}{$\begin{array}{l}\text { Immediate } \\
\text { contact } \\
\text { telephone }\end{array}$} & \multirow{2}{*}{\multicolumn{3}{|c|}{ Entry Requirement $(\mathrm{Y} / \mathrm{N})$}} & \multicolumn{5}{|c|}{ Selection Criteria (Individual Scores) } & \multirow[b]{3}{*}{ 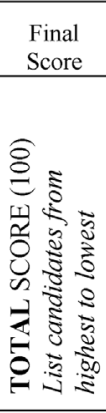 } & \multirow{3}{*}{ Rank } \\
\hline & & & & & & \multicolumn{4}{|c|}{$1-4$. Short-1isting $(70 \%)$} & \multirow[t]{2}{*}{ 5. Interview $(30 \%)$} & & \\
\hline & & & 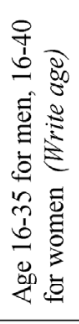 & 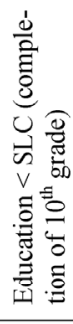 & 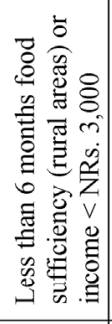 & 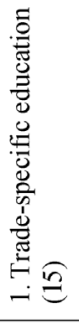 & 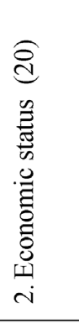 & 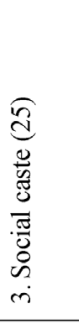 & 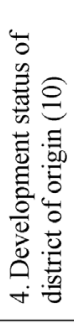 & & & \\
\hline 1 & Jane Doe 1 & 12345678 & 28 & $\mathrm{Y}$ & $\mathrm{Y}$ & 15 & 20 & 20 & 10 & 27 & 92 & 1 \\
\hline 2 & Jane Doe 2 & 12345678 & 29 & Y & Y & 15 & 20 & 20 & 10 & 25 & 90 & 2 \\
\hline 3 & John Doe 1 & 12345678 & 26 & Y & Y & 15 & 20 & 20 & 10 & 24 & 89 & 3 \\
\hline 4 & Jane Doe 3 & 12345678 & 20 & Y & Y & 15 & 20 & 20 & 0 & 30 & 85 & 4 \\
\hline 5 & Jane Doe 4 & 12345678 & 21 & $\mathrm{Y}$ & $\mathrm{Y}$ & 15 & 20 & 20 & 5 & 20 & 80 & 5 \\
\hline 6 & John Doe 2 & 12345678 & 24 & $\mathrm{Y}$ & $\mathrm{Y}$ & 15 & 15 & 20 & 5 & 25 & 80 & 6 \\
\hline 7 & Jane Doe 5 & 12345678 & 19 & Y & Y & 15 & 20 & 15 & 0 & 29 & 79 & 7 \\
\hline 8 & Jane Doe 6 & 12345678 & 33 & $\mathrm{Y}$ & $\mathrm{Y}$ & 15 & 15 & 25 & 10 & 13 & 78 & 8 \\
\hline 9 & John Doe 3 & 12345678 & 17 & $\mathrm{Y}$ & $\mathrm{Y}$ & 10 & 15 & 20 & 5 & 28 & 78 & 9 \\
\hline 10 & Jane Doe 7 & 12345678 & 21 & $\mathrm{Y}$ & $\mathrm{Y}$ & 15 & 20 & 15 & 5 & 22 & 77 & 10 \\
\hline 11 & Jane Doe 8 & 12345678 & 27 & $\mathrm{Y}$ & $\mathrm{Y}$ & 15 & 15 & 10 & 10 & 26 & 76 & 11 \\
\hline 12 & John Doe 4 & 12345678 & 23 & $\mathrm{Y}$ & Y & 15 & 20 & 10 & 10 & 20 & 75 & 12 \\
\hline 13 & Jane Doe 9 & 12345678 & 18 & $\mathrm{Y}$ & $\mathrm{Y}$ & 15 & 15 & 20 & 0 & 25 & 75 & 13 \\
\hline 14 & Jane Doe 10 & 12345678 & 35 & $\mathrm{Y}$ & $\mathrm{Y}$ & 15 & 15 & 20 & 0 & 23 & 73 & 14 \\
\hline 15 & John Doe 5 & 12345678 & 19 & $\mathrm{Y}$ & $\mathrm{Y}$ & 15 & 15 & 20 & 5 & 18 & 73 & 15 \\
\hline 16 & Jane Doe 11 & 12345678 & 22 & $\mathrm{Y}$ & $\mathrm{Y}$ & 15 & 0 & 20 & 10 & 27 & 72 & 16 \\
\hline 17 & Jane Doe 12 & 12345678 & 30 & $\mathrm{Y}$ & $\mathrm{Y}$ & 5 & 20 & 25 & 0 & 16 & 66 & 17 \\
\hline 18 & John Doe 6 & 12345678 & 25 & $\mathrm{Y}$ & $\mathrm{Y}$ & 15 & 10 & 20 & 5 & 15 & 65 & 18 \\
\hline 19 & Jane Doe 13 & 12345678 & 24 & $\mathrm{Y}$ & $\mathrm{Y}$ & 15 & 15 & 10 & 5 & 10 & 55 & 19 \\
\hline 20 & John Doe 7 & 12345678 & 32 & $\mathrm{Y}$ & $\mathrm{Y}$ & 15 & 15 & 10 & 5 & 6 & 51 & 20 \\
\hline
\end{tabular}

Notes: Red line indicates cut-off between accepted and rejected candidates. Candidates are sampled for the survey if their score is within a range of the cut-off score plus/minus 20 percent. The shaded area represents candidates who would have been sampled for the baseline survey based on this example.

Fig. A2. Sample ranking form. 


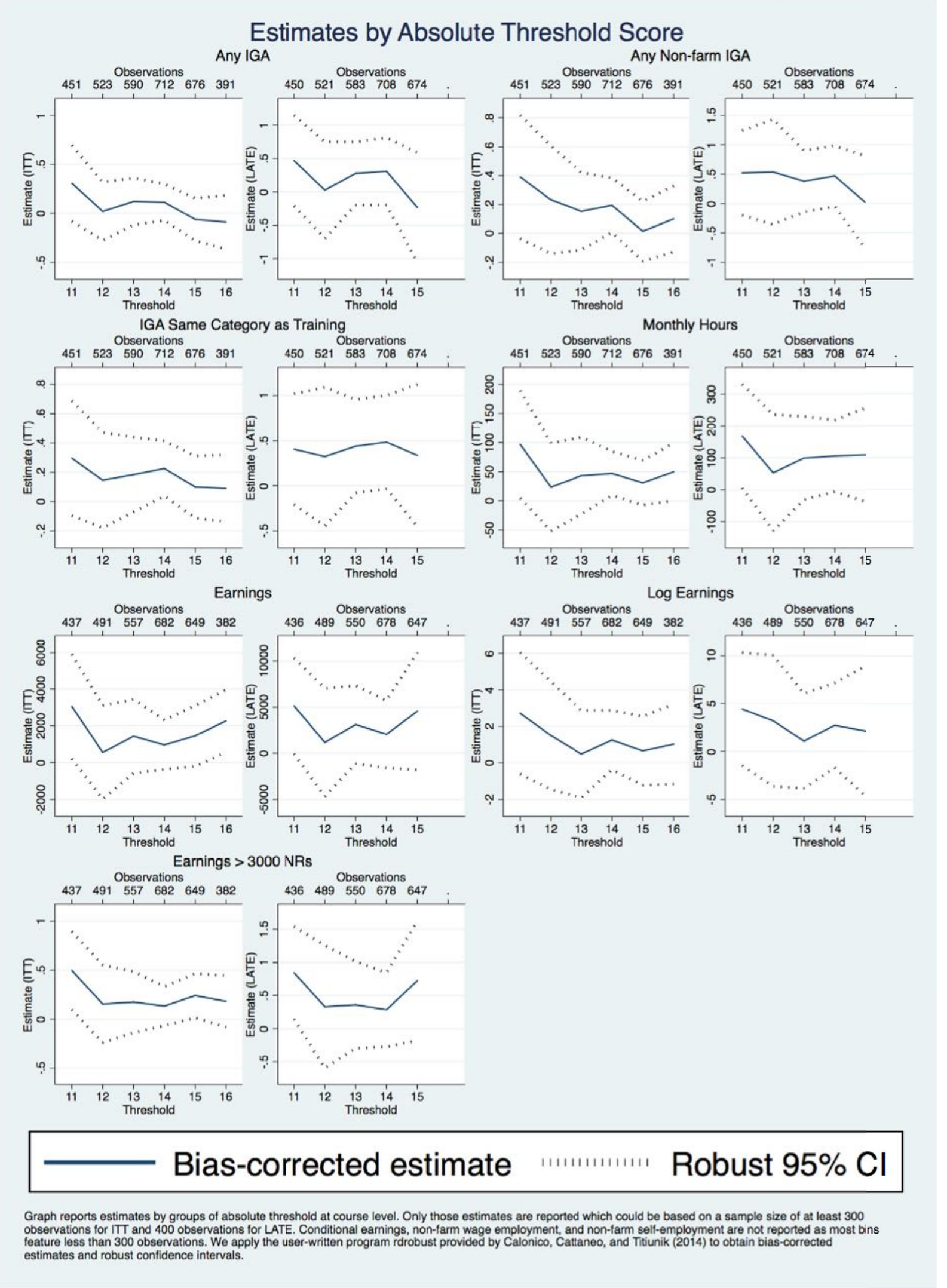

Fig. A3. Effect sizes by different absolute threshold values. 
Any IGA

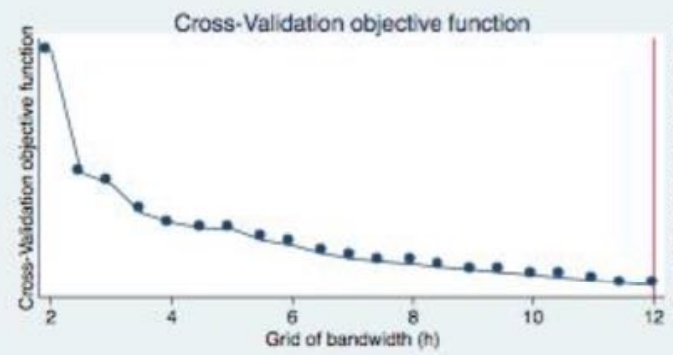

Any Non-farm Wage-employed IGA

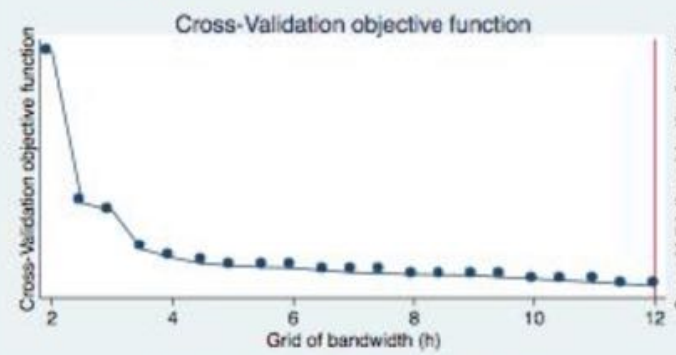

IGA Same Category as Training

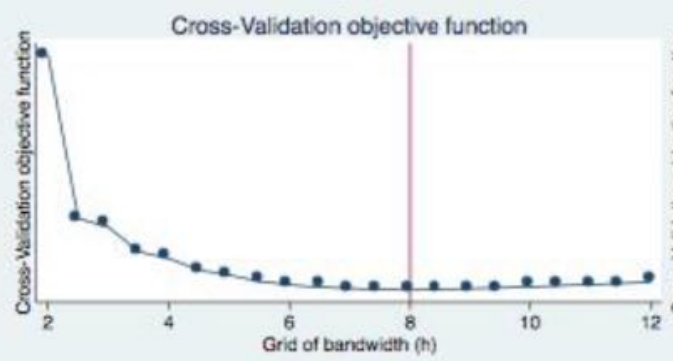

Earnings

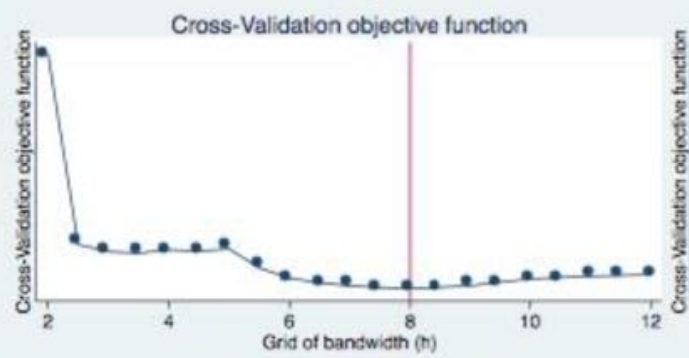

Earnings $>3000$ NRs

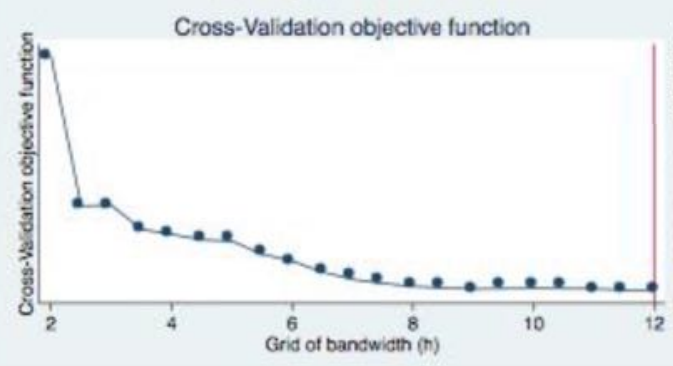

Any Non-farm IGA

Cross-Validation objective function

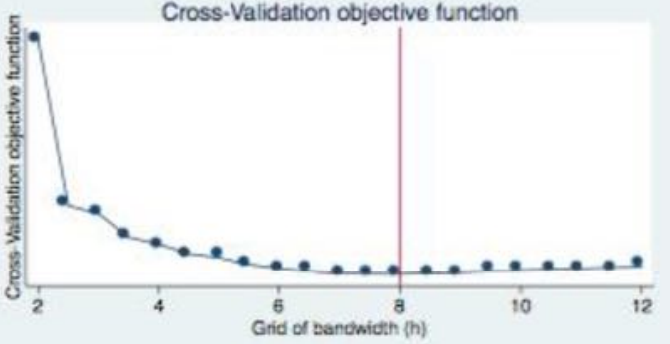

Any Non-farm Self-employed IGA

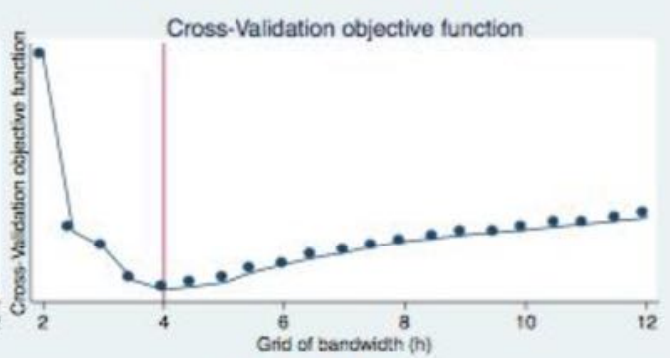

Monthly Hours

Cross-Validation objective function

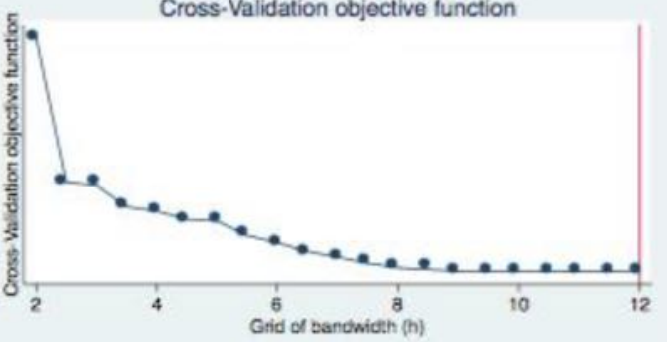

Log Earnings

Cross-Validation objective function

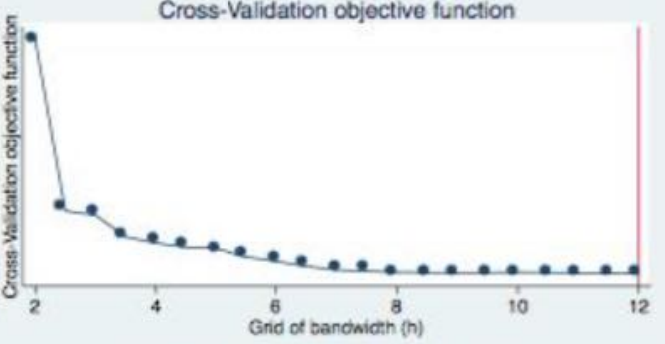

Earnings, Cond. on Any IGA

Cross-Validation objective function

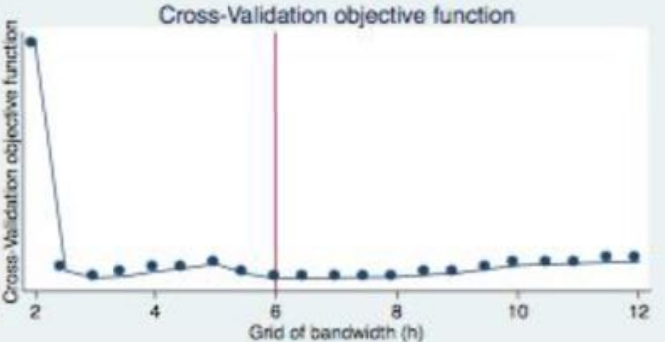

Fig. A4. Cross-validation function for outcomes in levels. 
Any IGA

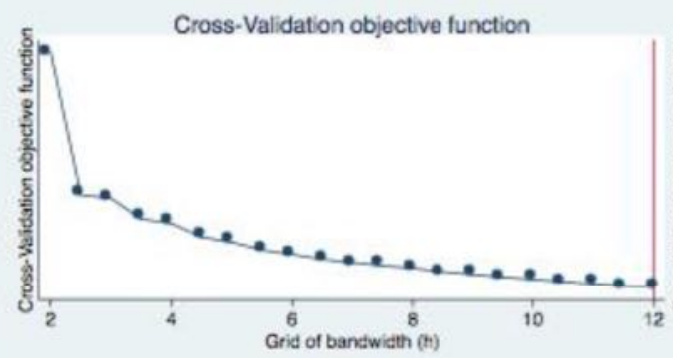

Any Non-farm Wage-employed IGA

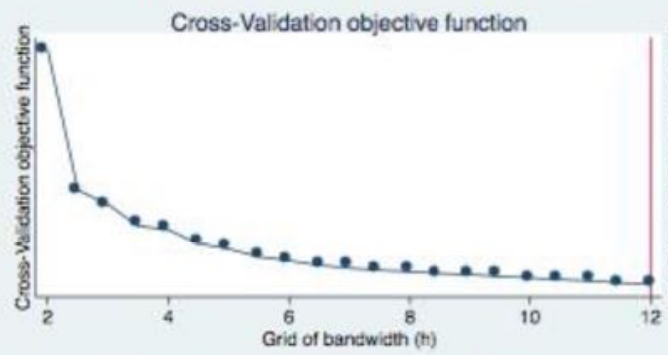

IGA Same Category as Training

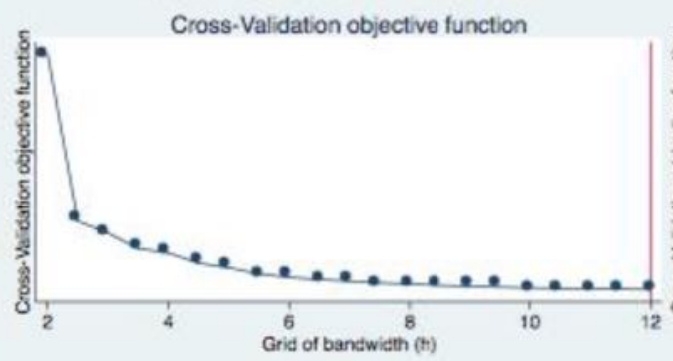

Earnings

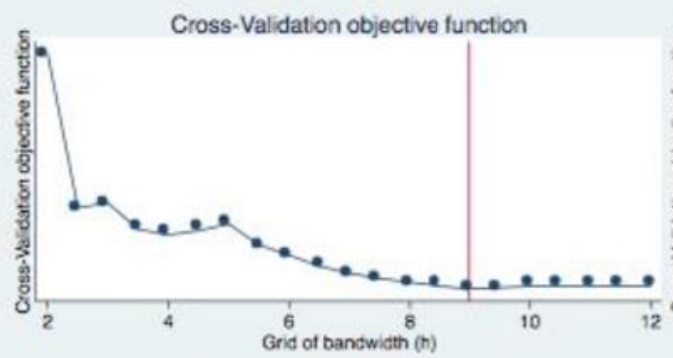

Earnings $>3000$ NRs

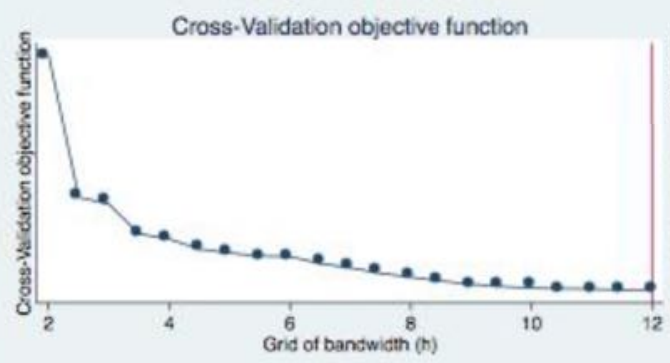

Any Non-farm IGA

Cross-Validation objective function

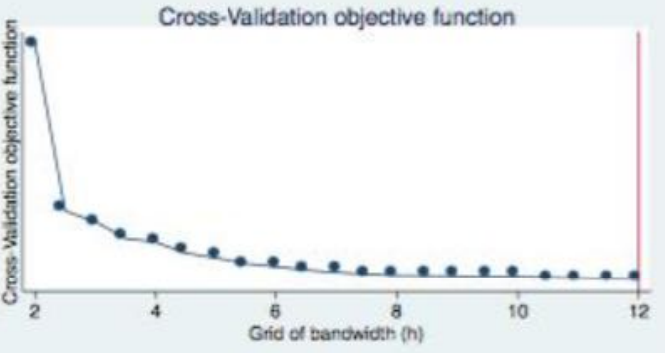

Any Non-farm Self-employed IGA

Cross-Validation objective function

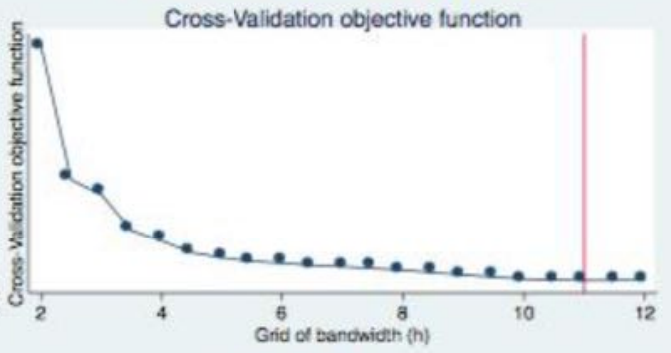

Monthly Hours

Cross-Validation objective function

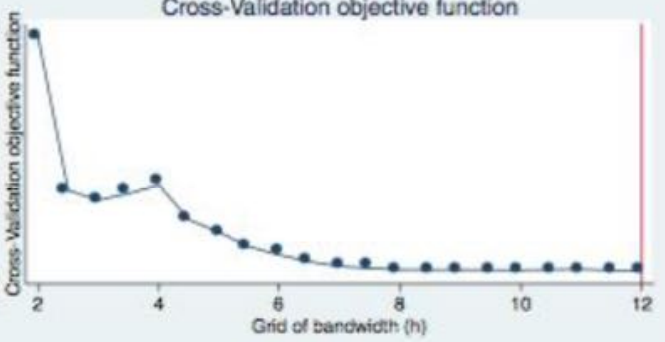

Log Earnings

Cross-Validation objective function

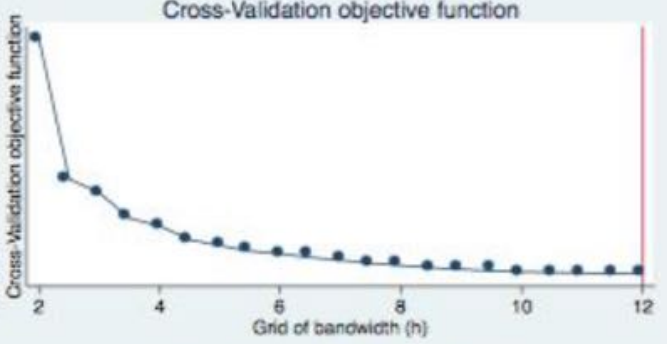

Earnings, Cond. on Any IGA

Cross-Validation objective function

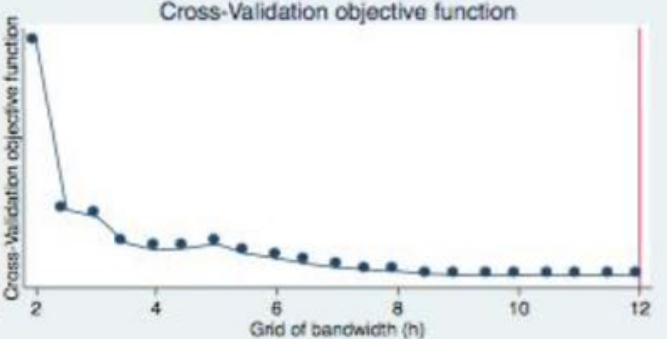

Fig. A5. Cross-validation function for differenced outcomes. 
Table A1

Original and reconstructed score components.

\begin{tabular}{|c|c|c|c|c|c|c|}
\hline \multirow{2}{*}{$\begin{array}{l}\text { Sub- } \\
\text { Score }\end{array}$} & \multirow{2}{*}{$\begin{array}{l}\text { Total } \\
\text { weight }\end{array}$} & \multirow[t]{2}{*}{ Basis for evaluation } & \multirow[t]{2}{*}{ Indicators } & \multirow{2}{*}{$\frac{\text { Original Score }}{\text { Assigned Sub-Score }}$} & \multicolumn{2}{|c|}{ Reconstructed Score } \\
\hline & & & & & $\begin{array}{l}\text { Assigned } \\
\text { Sub-Score }\end{array}$ & Source \\
\hline 1 & $15 \%$ & $\begin{array}{l}\text { Trade-specific } \\
\text { education requirement }\end{array}$ & $\begin{array}{l}\text { Compulsory prerequisite: All candidates must meet the minimum } \\
\text { requirement for the training they applied to* }\end{array}$ & $\begin{array}{l}15(0,5 \text { or } 10 \text { in } \\
\text { exceptional cases) }\end{array}$ & $\begin{array}{l}\text { Integers of } \\
0-3\end{array}$ & Predicted \\
\hline \multirow[t]{3}{*}{2} & \multirow[t]{3}{*}{$20 \%$} & \multirow[t]{3}{*}{ Economic poverty } & Less than 3 months of food sufficiency & 20 & 4 & \multirow{3}{*}{$\begin{array}{l}\text { Application } \\
\text { form data }\end{array}$} \\
\hline & & & $\begin{array}{l}\text { Less than } 6 \text { months of food sufficiency or less than } 3000 \text { per capita } \\
\text { family income from non-farm based income }\end{array}$ & 15 & 3 & \\
\hline & & & $\begin{array}{l}\text { More than } 6 \text { months of food sufficiency and per capita family income } \\
\text { from non-farm based income equal to or more than } 3000\end{array}$ & 0 & 0 & \\
\hline \multirow[t]{5}{*}{3} & \multirow[t]{5}{*}{$25 \%$} & \multirow[t]{5}{*}{ Social caste } & $\begin{array}{l}\text { Women: Dalit women or women from the following special groups: } \\
\text { widows; internally displaced; ex-combatants; physically disabled; } \\
\text { HIV-infected infected }\end{array}$ & 25 & 5 & \multirow[t]{5}{*}{$\begin{array}{l}\text { Application } \\
\text { form data }\end{array}$} \\
\hline & & & Women: Economically poor women not referred to above & 20 & 4 & \\
\hline & & & $\begin{array}{l}\text { Men: Dalit, Janjati, Madhesi men or men from the following special } \\
\text { groups: internally displaced; ex-combatants; physically disabled; } \\
\text { HIV-infected infected }\end{array}$ & 15 & 3 & \\
\hline & & & Men: Economically poor men not referred to above & 10 & 2 & \\
\hline & & & Neither of the above & 0 & 0 & \\
\hline \multirow[t]{3}{*}{4} & \multirow[t]{3}{*}{$10 \%$} & \multirow{3}{*}{$\begin{array}{l}\text { Development status of } \\
\text { district of origin }\end{array}$} & Least developed districts & 10 & 2 & \multirow{4}{*}{$\begin{array}{l}\text { Application } \\
\text { form data }\end{array}$} \\
\hline & & & Moderately developed districts & 5 & 1 & \\
\hline & & & Developed districts & 0 & 0 & \\
\hline \multicolumn{4}{|c|}{ Preliminary score for short-listing (Sub - total) } & 70 & 14 & \\
\hline 5 & $30 \%$ & Interview & $\begin{array}{l}\text { Commitment, Motivation, Attitude, Aptitude, Clear Vision for } \\
\text { Employment and Enterprising }\end{array}$ & $0-30$ & $0-6$ & Predicted \\
\hline \multicolumn{4}{|c|}{ Total score after interview } & 100 & 20 & \\
\hline
\end{tabular}

Notes: "If candidates did not fulfill the course specific education prerequisites they were not eligible for short-listing and immediately rejected. In exceptional cases (approx. 9 percent of the sample) this criterion was not adhered to and instead applicants received 0, 5, or 10 points. When reconstructing this component, we therefore allow for integer values between 0 and 3 .

Table A2

Develeopment status of Nepal districts.

\begin{tabular}{lll}
\hline Developed District & Moderately Developed District & Least Developed District \\
\hline Kathmandu & Makawanpur & Ramechhap \\
Chitwan & Gulmi & Parsa \\
Jhapa & Surkhet & Rasuwa \\
Bhaktapur & Solukhumbu & Kapilbastu \\
Lalitpur & Banke & Bara \\
Kaski & Bhojpur & Dadeldhura \\
Dhankuta & Gorkha & Darchula \\
Palpa & Taplejung & Siraha \\
Syangja & Bardiya & Jajarkot \\
Manang & Kanchanpur & Rukum \\
Morang & Nuwakot & Sarlahi \\
Illam & Nawalparasi & Baitadi \\
Rupandehi & Khotang & Dailekh \\
Sunsari & Okhaldhunga & Rolpa \\
Kabhreplanchok & Kailali & Mahotari \\
Tanahu & Dolakha & Doti \\
Terhathum & Arghakhanchi & Dolpa \\
Sankhuwasabha & Udayapur & Rautahat \\
Mustang & Dhading & Jumla \\
Parbat & Salyan & Kalikot \\
Dang & Dhanusa & Bajura \\
Lamjung & Saptari & Achham \\
Panchthar & Sindhipalchok & Bajhang \\
Baglung & Sundhuli & Humla \\
Myagdi & Pyuthan & Mugu \\
\hline Source: Districts of Nepal, Indicators of Development. Updated 2003. CBS/Nepal, ICIMOD. December, 2003.
\end{tabular}


Table A3

Correlation of 5th sub-score with other score components.

\begin{tabular}{|c|c|c|c|}
\hline & Sub-Score 5 & Sub-Score 5 & Sub-Score 5 \\
\hline & (1) & (2) & (3) \\
\hline Aggregated Sub-Scores 1 to 4 & $\begin{array}{l}-0.220^{* * *} \\
(0.021)\end{array}$ & & \\
\hline Sub-Score 1 (Trade-specif. Edu.) & & $\begin{array}{l}0.117^{*} \\
(0.062)\end{array}$ & $\begin{array}{l}2.752^{* * *} \\
(0.431)\end{array}$ \\
\hline Sub-Score 2 (Econ. Poverty) & & $\begin{array}{l}-0.182^{* * *} \\
(0.029)\end{array}$ & $\begin{array}{l}1.046^{*} \\
(0.551)\end{array}$ \\
\hline Sub-Score 3 (Social Caste) & & $\begin{array}{l}-0.348^{* * *} \\
(0.031)\end{array}$ & $\begin{array}{l}1.013^{* * *} \\
(0.350)\end{array}$ \\
\hline Sub-Score 4 (Development Status of Dist. Of Origin) & & $\begin{array}{l}-0.473^{* * *} \\
(0.095)\end{array}$ & $\begin{array}{l}3.560 * * * \\
(1.354)\end{array}$ \\
\hline SS $1 \times$ SS 2 & & & $\begin{array}{l}-0.120^{* * *} \\
(0.039)\end{array}$ \\
\hline SS $1 \times$ SS 3 & & & $\begin{array}{l}-0.136^{* * *} \\
(0.027)\end{array}$ \\
\hline SS $1 \times$ SS 4 & & & $\begin{array}{l}-0.379^{* * *} \\
(0.101)\end{array}$ \\
\hline SS $2 \times$ SS 3 & & & $\begin{array}{l}-0.049 \\
(0.030)\end{array}$ \\
\hline SS $2 \times$ SS 4 & & & $\begin{array}{l}-0.194 * * \\
(0.096)\end{array}$ \\
\hline SS $3 \times$ SS 4 & & & $\begin{array}{l}-0.278^{* * *} \\
(0.087)\end{array}$ \\
\hline SS $1 \times$ SS $2 \times$ SS 3 & & & $\begin{array}{l}0.006^{* * *} \\
(0.002)\end{array}$ \\
\hline SS $1 \times$ SS $2 \times$ SS 4 & & & $\begin{array}{l}0.019 * * * \\
(0.007)\end{array}$ \\
\hline SS $1 \times$ SS $3 \times$ SS 4 & & & $\begin{array}{l}0.026^{* * *} \\
(0.006)\end{array}$ \\
\hline SS $2 \times$ SS $3 \times$ SS 4 & & & $\begin{array}{l}0.013^{* *} \\
(0.006)\end{array}$ \\
\hline SS $1 \times$ SS $2 \times$ SS $3 \times$ SS 4 & & & $\begin{array}{l}-0.001^{* * *} \\
(0.000)\end{array}$ \\
\hline $\mathrm{N}$ & 4090 & 4090 & 4090 \\
\hline Adj. R2 & 0.38 & 0.39 & 0.40 \\
\hline
\end{tabular}

Notes: All models include event dummies. ${ }^{* * *}, * *$, and * denote significance at the 1,5 , and 10 percent level, respectively.

Table A4

Attrition.

\begin{tabular}{|c|c|c|c|c|c|c|c|c|}
\hline & \multicolumn{4}{|c|}{ Pooled Cohorts, 1st Follow-Up } & \multicolumn{4}{|c|}{2010 Cohort, 2nd Follow-Up } \\
\hline & (1) & (2) & (3) & (4) & (5) & (6) & (7) & (8) \\
\hline "Above Threshold" & $\begin{array}{l}0.008 \\
(0.010)\end{array}$ & $\begin{array}{l}0.017 \\
(0.019)\end{array}$ & $\begin{array}{l}0.007 \\
(0.010)\end{array}$ & $\begin{array}{l}0.016 \\
(0.019)\end{array}$ & $\begin{array}{l}-0.011 \\
(0.027)\end{array}$ & $\begin{array}{l}-0.047 \\
(0.045)\end{array}$ & $\begin{array}{c}-0.004 \\
(0.029)\end{array}$ & $\begin{array}{c}-0.052 \\
(0.047)\end{array}$ \\
\hline Female X "Above Threshold" & & $\begin{array}{l}-0.020 \\
(0.021)\end{array}$ & & $\begin{array}{l}-0.014 \\
(0.021)\end{array}$ & & $\begin{array}{l}0.059 \\
(0.066)\end{array}$ & & $\begin{array}{l}0.080 \\
(0.066)\end{array}$ \\
\hline Female & & $\begin{array}{l}0.077^{* * *} \\
(0.021)\end{array}$ & $\begin{array}{l}0.066^{* * *} \\
(0.014)\end{array}$ & $\begin{array}{l}0.074 * * * \\
(0.020)\end{array}$ & & $\begin{array}{l}-0.026 \\
(0.060)\end{array}$ & $\begin{array}{l}0.026 \\
(0.035)\end{array}$ & $\begin{array}{l}-0.019 \\
(0.056)\end{array}$ \\
\hline Age & & & $\begin{array}{l}0.004 * * * \\
(0.001)\end{array}$ & $\begin{array}{l}0.004 * * * \\
(0.001)\end{array}$ & & & $\begin{array}{l}0.007^{* *} \\
(0.003)\end{array}$ & $\begin{array}{l}0.007^{* *} \\
(0.003)\end{array}$ \\
\hline Parent & & & $\begin{array}{l}-0.003 \\
(0.019)\end{array}$ & $\begin{array}{l}-0.003 \\
(0.019)\end{array}$ & & & $\begin{array}{l}-0.006 \\
(0.045)\end{array}$ & $\begin{array}{l}-0.009 \\
(0.045)\end{array}$ \\
\hline Married & & & $\begin{array}{l}0.011 \\
(0.019)\end{array}$ & $\begin{array}{l}0.011 \\
(0.019)\end{array}$ & & & $\begin{array}{l}0.006 \\
(0.043)\end{array}$ & $\begin{array}{l}0.010 \\
(0.043)\end{array}$ \\
\hline Dalit & & & $\begin{array}{l}-0.052^{* *} \\
(0.023)\end{array}$ & $\begin{array}{l}-0.052^{* *} \\
(0.023)\end{array}$ & & & $\begin{array}{l}-0.052 \\
(0.062)\end{array}$ & $\begin{array}{l}-0.053 \\
(0.062)\end{array}$ \\
\hline Janjati & & & $\begin{array}{l}-0.014 \\
(0.012)\end{array}$ & $\begin{array}{l}-0.014 \\
(0.012)\end{array}$ & & & $\begin{array}{l}0.109 * * * \\
(0.032)\end{array}$ & $\begin{array}{l}0.110 * * * \\
(0.032)\end{array}$ \\
\hline Any IGA at baseline & & & $\begin{array}{l}0.017 \\
(0.011)\end{array}$ & $\begin{array}{l}0.017 \\
(0.011)\end{array}$ & & & $\begin{array}{l}0.024 \\
(0.027)\end{array}$ & $\begin{array}{l}0.023 \\
(0.027)\end{array}$ \\
\hline $\mathrm{N}$ & 4585 & 4585 & 4585 & 4585 & 1547 & 1547 & 1547 & 1547 \\
\hline Training provider dummies & Yes & Yes & Yes & Yes & Yes & Yes & Yes & Yes \\
\hline District dummies & Yes & Yes & Yes & Yes & Yes & Yes & Yes & Yes \\
\hline
\end{tabular}

Notes: All models include district and training provider dummies. In Columns (3), (4), (7), and (8) indicators are included which flag missing values for each of the control variables, respectively. All models are estimated based on the reconstructed score. The difference in sample size between the initial baseline sample and the sample we use in this analysis arises due to missing values in the variables that were necessary to reconstruct the score variable, which determines assignment. All standard errors are clustered at event level. ***, **, and * denote significance at the 1,5 , and 10 percent level, respectively. 
Table A5

Bandwidth sensitivity.

\begin{tabular}{|c|c|c|c|c|c|c|c|c|c|c|}
\hline & $\begin{array}{l}\text { Any IGA } \\
(1=\text { Yes })\end{array}$ & $\begin{array}{l}\text { Any non- } \\
\text { farm IGA } \\
(1=\text { Yes })\end{array}$ & $\begin{array}{l}\text { Non-farm } \\
\text { wage IGA } \\
(1=\text { Yes })\end{array}$ & $\begin{array}{l}\text { Non-farm } \\
\text { self IGA } \\
(1=\text { Yes })\end{array}$ & $\begin{array}{l}\text { Trade- } \\
\text { specific IGA } \\
(1=\text { Yes })\end{array}$ & $\begin{array}{l}\text { Hours } \\
\text { worked in } \\
\text { past month }\end{array}$ & Earnings & $\begin{array}{l}\text { Logged } \\
\text { earnings }\end{array}$ & $\begin{array}{l}\text { Earnings }>3000 \\
\text { NRs. }(1=\text { Yes })\end{array}$ & $\begin{array}{l}\text { Earnings, } \\
\text { conditional on } \\
\text { any IGA }\end{array}$ \\
\hline & (1) & (2) & (3) & (4) & (5) & (6) & (7) & (8) & (9) & (10) \\
\hline \multicolumn{11}{|c|}{ Panel A: LATE, DD (Reconstructed Score) } \\
\hline 2 Index & 0.19 & $0.50 * *$ & 0.35 & 0.14 & $0.43^{* *}$ & $121.8^{* * *}$ & $3387 * *$ & 2.33 & $0.43^{* *}$ & 3058 \\
\hline Scores & $(0.21)$ & $(0.20)$ & $(0.31)$ & $(0.27)$ & $(0.20)$ & $(42.98)$ & $(1341)$ & (1.63) & $(0.21)$ & (2254) \\
\hline Observations & 2133 & 2133 & 1364 & 1364 & 2133 & 2133 & 2049 & 2049 & 2049 & 1012 \\
\hline F-statistic & 27.50 & 27.50 & 12.22 & 12.22 & 27.50 & 27.50 & 27.83 & 27.83 & 27.83 & 12.85 \\
\hline 3 Index & 0.13 & $0.38^{* *}$ & 0.28 & 0.18 & $0.45^{* * *}$ & $77.66^{* *}$ & $2319^{* *}$ & 1.52 & $0.34 * *$ & 1722 \\
\hline Scores & $(0.16)$ & $(0.15)$ & $(0.19)$ & $(0.17)$ & $(0.16)$ & $(31.35)$ & (1083) & (1.27) & $(0.16)$ & (1645) \\
\hline Observations & 2874 & 2874 & 1862 & 1862 & 2874 & 2874 & 2759 & 2759 & 2759 & 1411 \\
\hline F-statistic & 36.18 & 36.18 & 20.31 & 20.31 & 36.18 & 36.18 & 37.95 & 37.95 & 37.95 & 17.43 \\
\hline 4 Index & 0.09 & $0.31 * *$ & 0.15 & $0.25^{*}$ & $0.45^{* * *}$ & $58.86^{* *}$ & $1755^{* *}$ & 1.26 & $0.24 * *$ & 1258 \\
\hline Scores & $(0.12)$ & $(0.12)$ & $(0.13)$ & $(0.14)$ & $(0.13)$ & $(24.97)$ & $(872)$ & (1.06) & $(0.12)$ & (1097) \\
\hline Observations & 3340 & 3340 & 2145 & 2145 & 3340 & 3340 & 3202 & 3202 & 3202 & 1622 \\
\hline F-statistic & 62.42 & 62.42 & 33.90 & 33.90 & 62.42 & 62.42 & 65.38 & 65.38 & 65.38 & 37.29 \\
\hline 5 Index & 0.07 & $0.29 * * *$ & 0.10 & $0.25^{* *}$ & $0.41^{* * *}$ & $52.67 * *$ & $1666^{* *}$ & 1.29 & $0.24 * *$ & 1393 \\
\hline Scores & $(0.11)$ & $(0.10)$ & $(0.12)$ & $(0.12)$ & $(0.12)$ & (20.54) & $(744)$ & $(0.92)$ & $(0.10)$ & (994) \\
\hline Observations & 3685 & 3685 & 2391 & 2391 & 3685 & 3685 & 3530 & 3530 & 3530 & 1778 \\
\hline F-statistic & 77.89 & 77.89 & 42.88 & 42.88 & 77.89 & 77.89 & 79.88 & 79.88 & 79.88 & 42.02 \\
\hline 10 Index & 0.11 & $0.29 * * *$ & 0.09 & $0.28 * *$ & $0.41^{* * *}$ & $45.13^{* *}$ & $1685^{* *}$ & $1.53^{*}$ & $0.28^{* * *}$ & 1662 \\
\hline Scores & $(0.10)$ & $(0.10)$ & $(0.11)$ & $(0.12)$ & $(0.12)$ & (20.99) & (705) & $(0.89)$ & $(0.11)$ & (1017) \\
\hline Observations & 4000 & 4000 & 2604 & 2604 & 4000 & 4000 & 3834 & 3834 & 3834 & 1929 \\
\hline F-statistic & 83.98 & 83.98 & 51.84 & 51.84 & 83.98 & 83.98 & 82.98 & 82.98 & 82.98 & 38.61 \\
\hline \multicolumn{11}{|c|}{ Panel B: ITT, DD (Reconstructed Score) } \\
\hline 2 Index & 0.06 & $0.15^{* *}$ & 0.08 & 0.03 & $0.13^{* *}$ & $36.23^{* * *}$ & $1033^{* * *}$ & 0.71 & $0.13^{* *}$ & 885 \\
\hline Scores & $(0.06)$ & $(0.06)$ & $(0.07)$ & $(0.06)$ & $(0.06)$ & $(12.15)$ & $(392)$ & $(0.51)$ & $(0.06)$ & $(602)$ \\
\hline 3 Index & 0.03 & $0.11 * *$ & 0.07 & 0.05 & $0.13^{* * *}$ & $21.29 * *$ & $662^{* *}$ & 0.42 & $0.10 * *$ & 455 \\
\hline Scores & $(0.04)$ & $(0.04)$ & $(0.05)$ & $(0.04)$ & $(0.05)$ & $(8.66)$ & $(309)$ & $(0.38)$ & $(0.04)$ & $(437)$ \\
\hline 4 Index & 0.03 & $0.10^{* *}$ & 0.05 & $0.07^{*}$ & $0.15^{* * *}$ & $18.97^{* *}$ & $587 * *$ & 0.42 & $0.08^{* *}$ & 435 \\
\hline Scores & $(0.04)$ & $(0.04)$ & $(0.04)$ & $(0.04)$ & $(0.04)$ & $(8.26)$ & (295) & $(0.37)$ & $(0.04)$ & $(386)$ \\
\hline 5 Index & 0.02 & $0.10 * * *$ & 0.03 & $0.08 * *$ & $0.14 * * *$ & $17.88^{* *}$ & $579 * *$ & 0.45 & $0.09 * *$ & 473 \\
\hline Scores & $(0.04)$ & $(0.04)$ & $(0.04)$ & $(0.04)$ & $(0.04)$ & $(7.20)$ & $(264)$ & $(0.33)$ & $(0.04)$ & (344) \\
\hline 10 Index & 0.03 & $0.09 * * *$ & 0.03 & $0.08^{* * *}$ & $0.13^{* * *}$ & $14.11^{* *}$ & $532^{* *}$ & $0.49 *$ & $0.09 * * *$ & 494 \\
\hline Scores & $(0.03)$ & $(0.03)$ & $(0.03)$ & $(0.03)$ & $(0.04)$ & $(6.60)$ & $(223)$ & $(0.29)$ & $(0.03)$ & (305) \\
\hline
\end{tabular}

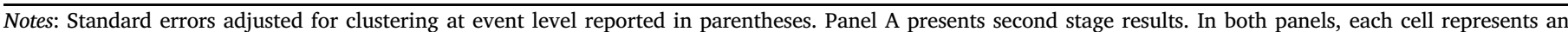

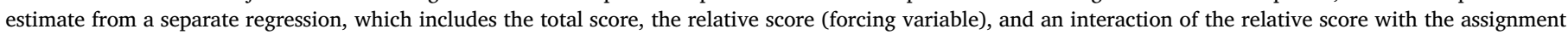

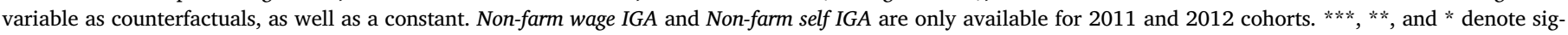
nificance at the 1,5 , and 10 percent level.

\section{B. Robustness tests based on propensity score techniques}

We estimate:

$Y_{i t}=\alpha+\delta\left(A_{i t}\right.$ x $\left._{\text {Treat }}{ }_{i t}\right)+u_{i}+v_{t}+\varepsilon_{i t}$

$\mathrm{Y}_{\mathrm{it}}$ is the employment outcome of interest for individual $i$ from training event $j$ at time $t$; Treat is an indicator, equal to 1 for the treatment group and 0 for control; $\mathrm{A}_{\mathrm{it}}$ is an indicator for the period when treatment occurs; $u_{i}$ captures program effects; $v_{t}$ captures the time effects, $\varepsilon_{i t}$, is an idiosyncratic error term, clustered by training event. After estimating a propensity score, ${ }^{35}$ we derive the estimated treatment effect using two methods: "inverse propensity score weighting" (IPSW) and nearest neighbor matching (NN). In the IPSW method individuals are weighted according to the inverse of their estimated propensity to participate in the program. The weighted observations are then used in a DID regression. We present this method estimates under the IPSW specification in the Appendix B tables. ${ }^{36,37}$ The NN matching algorithm, in which each individual in the treatment group is compared to a fixed number of control observations (in our estimation we use four observations) with the closest propensity score. We present "NN specification" in Appendix B. Following Smith and Todd (2005), we estimate the difference-in-difference matching estimator for the training program effect $\delta$ as follows:

$\widehat{\delta_{M}}=\frac{1}{N_{T}} \sum_{i \varepsilon T}\left[\left(y_{i t_{1}}-y_{i t_{0}}\right)-\sum_{j \in C} W_{i j}\left(y_{j t_{1}}-y_{j t_{0}}\right)\right]$

\footnotetext{
35 We employ various specifications, including the individual training score, the individual training score and demographic variables, the five subinterview scores and finally the demographic variables plus provider/district/cohort/city fixed effects. The results are stable across various specifications though we report the last specification based on demographic variables plus provider/district/cohort/city fixed effects because that specification yields the best overlap of treatment and control unit distributions in the common support area.

${ }^{36}$ We implement IPSW following Hirano et al. (2003).

37 This particular weighting method, as opposed to matching approaches, has the nice property of including all the data (unless weights are set to 0 ) and does not depend on random sampling, thus providing for replicability. We use a weighted least squares regression model, with weights of $1 / \hat{\pi}$ for the treatment group and $1 /(1-$ $ð$ ) for the control group, where $\pi$ is the estimated propensity score from (2). Standard errors are clustered by training event.
} 


\begin{tabular}{|c|c|c|c|c|c|}
\hline & Baseline mean for young women & Baseline mean for women & Young women & Older women & Difference \\
\hline & [Std Dev] & [Std Dev] & (1) & (2) & (3) \\
\hline Earnings $>3000$ NRs. $(1=$ Yes $)$ & $\begin{array}{l}0.071 \\
{[0.256]}\end{array}$ & $\begin{array}{l}0.131 \\
{[0.337]}\end{array}$ & $\begin{array}{l}0.165^{* * *} \\
(0.030)\end{array}$ & $\begin{array}{l}0.235^{* * *} \\
(0.036)\end{array}$ & $\begin{array}{l}-0.071 * \\
(0.040)\end{array}$ \\
\hline Clustered Standard Errors & & & Yes & Yes & Yes \\
\hline
\end{tabular}

Notes: Standard errors (reported in brackets) clustered at the event level where possible.

Younger women (aged 16 to 24) compared to older women (age 25 to 35).

$* * *$ Significant at the 1 percent level.

** Significant at the 5 percent level.

* Significant at the 10 percent level.

\section{References}

Abebe, G., Caria, S., Fafchamps, M., Falco, P., Franklin, S., Quinn, S., 2016a. Anonymity or Distance? Experimental Evidence on Obstacles to Youth Employment Opportunities". Mimeo. Stanford University.

Abebe, G., Caria, S., Fafchamps, M., Falco, P., Franklin, S., Quinn, S., Shilpi, F., 2016b. All the Fun of the (Job) Fair: Matching Firms and Workers in a Field Experiment in Ethiopia. Mimeo.

Abel, M., Burger, R., Piraino, P., 2016. The Value of Reference Letters: Experimental Evidence from South Africa. Mimeo. Harvard University.

Acevedo, P., Cruces, G., Gertler, P., Martiınez, S., 2017. Living up to Expectations: How Job Training Made Women Better off and Men Worse off. NBER Working Paper, No. 23264. NBER, Boston, MA.

Adoho, Franck, Chakravarty, Shubha, Korkoyah Jr., Dala T., Lundberg, Mattias, Tasneem, Afia, 2014. The Impact of an Adolescent Girls Employment Program: the EPAG Project in Liberia. World Bank Policy Research Working Paper, p. 6832.

Adhvaryu, Achyuta, Kala, Namrata, Nyshadham, Anant, 2016. The Skills to Pay the Bills: Returns to On-the-job Soft Skills Training. Mimeo.

AGI, 2013. Life Skills: what Are They, Why Do They Matter, and How Are They Taught? Learning from Practice Series The Adolescent Girls Initiative (AGI), World Bank. June 19, 2018. http://www.worldbank.org/content/dam/Worldbank/document/Gender/ 1323447_AGI_LearningFromPracticeSeries.pdf.

Almeida, Rita, Behrman, Jere, Robalino, David, 2012. The Right Skills for the Job? Rethinking Training Policies for Workers. World Bank Publications.

Alzúa, María L., Cruces, Guillermo, Lopez, Carolina, 2016. Youth training programs beyond employment. Evidence from a randomized controlled trial. Econ. Inq. 54 (4), 1839-1859.

Ashraf, Nava, Bau, Natalie, Low, Corinne, McGinnn, Kathleen, 2017. Negotiating a Better Future: How Interpersonal Skills Facilitate Inter-generational Investment. Mimeo.

Asian Development Bank, 2015. Women in the Workforce: an Unmet Potential in Asia and Pacific. Asian Development Bank.

Attanasio, Orazio, Kugler, Adriana, Meghir, Costas, 2011. Subsidizing vocational training for disadvantaged youth in Colombia: evidence from a randomized trial. Am. Econ. J. Appl. Econ. 3 (3), 188-220.

Attanasio, Orazio, Guarin, Arlen, Medina, Carlos, Meghir, Costas, 2015. Long-term Impacts of Vouchers for Vocational Training: Experimental Evidence from Colombia. NBER Working Paper, No. 21390. NBER, Boston, MA.

Bandiera, Oriana, Buehren, Nicholas, Burgess, Robin, Goldstein, Marcus, Gulesci, Selim, Rasul, Imran, Sulaiman, Munshi, 2017. Women's Empowerment in Action: Evidence from a Randomized Control Trial in Africa. Mimeo.

Banerjee, Biswajit, Knight, J.B., 1985. Caste discrimination in the Indian urban labour market. J. Dev. Econ. 17 (3), 277-307.

Bassi, V., Nansamba, A., 2017. Information Frictions in the Labor Market: Evidence from a Field Experiment in Uganda. Mimeo. UCL.

Beam, E., 2016. Do job fairs matter? Experimental evidence on the impact of job fair attendance. J. Dev. Econ. 120, 32-40.

Becker, Sascha O., Egger, Peter H., von Ehrlich, Maximilian, 2013. Absorptive capacity and the growth and investment effects of regional transfers: a regression discontinuity design with heterogeneous treatment effects. Am. Econ. J. Econ. Pol. 5 (4), 29-77.

Betcherman, Gordon, Godfrey, Martin, Puerto, Susana, Rother, Friederike, Stavreska, Antoneta, 2007. Global Inventory of Interventions to Support Young Workers. Synthesis Report. The World Bank.

Blattman, Christopher, Ralston, Laura, 2015. Generating Employment in Poor and Fragile States: Evidence from Labor Market and Entrepreneurship Programs. Mimeo.

Blattman, Christopher, Annan, Jeannie, 2016. Can employment reduce lawlessness and rebellion? A field experiment with high-risk men in a Fragile state. Am. Polit. Sci. Rev. 110 (1), 1-17.

Booth, Anne, 2016. Women, work and the family: is Southeast Asia different? Econ. Hist. Develop. Reg. 31 (1), 167-197.

Calonico, Sebastian, Cattaneo, Matias D., Titiunik, Rocio, 2014. Robust nonparametric confidence intervals for regression discontinuity designs. Econometrica 82 (6), 2295-2326.

Card, David, Kluve, Jochen, Weber, Andrea, 2010. Active labour market policy evaluations: a meta-analysis. Econ. J. 120, F451-F477.

Card, David, Ibarrarán, Pablo, Regalia, Ferdinando, Rosas, David, Soares, Yuri, 2011. The labor market impacts of youth training in the Dominican Republic. J. Labor Econ. 29 (2), 267-300.
Cattaneo, Matias D., Keele, Luke, Titiunik, Rocío, Vazquez-Bare, Gonzalo, 2016. Interpreting regression discontinuity designs with multiple cutoffs. J. Polit. 78 (4), 1229-1248.

Central Bureau of Statistics, 2009. Report on the Nepal Labour Force Survey 2008. Central Bureau of Statistics, National Planning Commission Secretariat, Government of Nepal.

Chay, Kenneth Y., McEwan, Patrick J., Urquiola, Miguel, 2005. The central role of noise in evaluating interventions that use test scores to rank schools. Am. Econ. Rev. 95 (4), 1237-1258.

Cho, Yoonyoung, Kalomba, Davie, Mobarak, Ahmed Mushfiq, Orozco, Victor, Wolfson, Derek, 2016. Gender Differences in the Effects of Vocational Training: Constraints on Women and Dropout Behavior. Mimeo.

Currie, Janet, Gruber, Jonathan, 1996a. Health insurance eligibility, utilization of medical care, and child health. Q. J. Econ. 111 (2), 431-466.

Currie, Janet, Gruber, Jonathan, 1996b. Saving babies: the efficacy and cost of recent changes in the medicaid eligibility of pregnant women. J. Polit. Econ. 104 (6), 1263-1296.

Cutler, David M., Gruber, Jonathan, 1996. Does public insurance crowd out private insurance? Q. J. Econ. 111 (2), 391-430.

Dammert, A., Galdo, J., Galdo, V., 2015. Integrating mobile phone technologies into labor-market intermediation: a multi-treatment experimental design. IZA J. Labor Develop. 4 (11).

Dar, Amit, Tzannatos, Zafris, 1999. Active Labor Market Programs: a Review of the Evidence from Evaluations. World Bank Social Protection Working Paper, 20116. The World Bank, Washington DC.

Dehejia, Rajeev H., Wahba, Sadek, 2002. Propensity score-matching methods for nonexperimental causal studies. Rev. Econ. Stat. 84 (1), 151-161.

Diaz, Juan, Rosas, David, 2016. Impact Evaluation of the Job Youth Training Program ProJoven. Inter-American Development Bank Working Paper, no. 693.

Fella, G., Gallipoli, G., 2014. Education and crime over the life cycle. Rev. Econ. Stud. 81 (4), 1484-1517.

Franklin, S., 2015. Location, Search Costs and Youth Unemployment: a Randomized Trial of Transport Subsidies in Ethiopia. CSAE Working Paper WPS/2015-11.

Frese, Michael, Mohr, Gisela, 1987. Prolonged unemployment and depression in older workers: a longitudinal study of intervening variables. Soc. Sci. Med. 25 (2), 173-178.

Galasso, Emanuela, Ravallion, Martin, Salvia, Agustin, 2004. Assisting the transition from workfare to work: a randomized experiment. Ind. Labor Relat. Rev. 57 (5), 128-142.

Goldsmith, Arthur H., Veum, Jonathan R., Darity, William, 1997. The impact of psychological and human capital on wages. Econ. Inq. 35 (4), 815-829.

Groh, Matthew, Krishnan, Nandini, McKenzie, David, Vishwanath, Tara, 2012. Soft Skills or Hard Cash? the Impact of Training and Wage Subsidy Programs on Female Youth Employment Programs in Jordan. Policy Research Working Paper, 6141. The World Bank, Washington DC.

Groh, M., McKenzie, D., Shammout, N., Vishwanath, T., 2015. Testing the importance of search frictions and matching through a randomized experiment in Jordan. IZA J. Labor Econ. 4 (7).

Groh, M., Krishnan, N., McKenzie, D., Vishwanath, T., 2016. Do wage subsidies provide a stepping stone to employment for recent college graduates? Evidence from a Randomized Experiment in Jordan. Rev. Econ. Stat. 98 (3), 488-502.

Hahn, Jinyong, Todd, Petra, Van der Klaauw, Wilbert, 2001. Identification and estimation of treatment effects with a regression discontinuity design. Econometrica 69 (1), 201-209.

Heckman, James, Krueger, Alan B., Friedman, B.M., 2004. Inequality in America. Cambridge.

Hirano, Keisuke, Imbens, Guido W., Ridder, Geert, 2003. Efficient estimation of average treatment effects using the estimated propensity score. Econometrica 71 (4), 1161-1189.

Hirshleifer, Sarojini, McKenzie, David, Almeida, Rita, Ridao-Cano, Cristobal, 2016. The impact of vocational training for the unemployed: experimental evidence from Turkey. Econ. J. 126, 2115-2146.

Honorati, Maddalena, 2015. The Impact of Private Sector Internship and Training on Urban Youth in Kenya. World Bank Policy Research Working Paper, 7404. The World Bank, Washington DC.

Hoxby, Caroline M., 2001. All school finance equalizations are not created equal. Q. J. Econ. 116 (4), 1189-1231. 
Ibarraran, Pablo, Kluve, Jochen, Ripani, Laura, Rosas, David, 2015. Experimental Evidence on the Long Term Impacts of a Youth Training Program. IDB Working Paper Series, p. 657.

Ibarraran, Pablo, Ripani, Laura, Taboada, Bibiana, Villa, Juan Miguel, Garcia, Brigida, 2014. Lifeskills, employability, and training for disadvantaged youth: evidence from a randomized evaluation design. IZA J. Labor Develop. 3 (10).

International Labour Organization (ILO), 2004. The Informal Economy and Workers in Nepal. International Labour Organization.

ILOSTAT. 2017. http://data.worldbank.org/indicator/SL.UEM.1524.ZS.

Imbens, Guido, Lemieux, Thomas, 2008. Regression discontinuity designs: a guide to practice. J. Econom. 142, 615-635.

Jensen, R., 2012. Do labor market opportunities affect young women's work and family decisions? Experimental evidence from India. Q. J. Econ. 127 (2), 753-792.

Katz, Elizabeth, 2008. Programs Promoting Young Women's Employment: what Works? The World Bank, Washington DC.

Klasen, Stephan, 2002. Low schooling for girls, slower growth for all? Cross-Country evidence on the effect of gender inequality in education on economic development. World Bank Econ. Rev. 16 (3), 345-373.

Kluve, Jochen, 2010. The effectiveness of European active labor market programs. Lab. Econ. 17, 904-918.

Knowles, Stephen, Lorgelly, Paula K., Owen, P. Dorian, 2002. Are educational gender gaps a brake on economic development? Some cross-country empirical evidence. Oxf. Econ. Pap. 54 (1), 118-149.

Lechner, Michael, Ruth, Miquel, Wunsch, Conny, 2011. Long-run effects of public sector sponsored training in West Germany. J. Eur. Econ. Assoc. 9 (4), 742-784.

Lee, David, Lemieux, Thomas, 2010. Regression discontinuity designs in economics. J. Econ. Lit. 48, 281-355.

Lenze, Jana, Klasen, Stephan, 2016. Does women's labor force participation reduce domestic violence? Evidence from Jordan. Fem. Econ. 23 (1), 1-29.

Levinsohn, J., Rankin, N., Roberts, G., Schöer, V., 2014. Wage Subsidies and Youth Employment in South Africa: Evidence from a Randomized Control Trial. Stellenbosch Economic Working Paper 02/14.

Linn, Margaret, Sandifer, Richard, Stein, Shayna, 1985. Effects of unemployment on mental and physical health. Am. J. Publ. Health 75 (5), 502-506.

Lokshin, Michael, Glinskaya, Elena, 2009. The effect of male migration on employment patterns of women in Nepal. World Bank Econ. Rev. 23 (3), 481-507.

Ludwig, Jens, Miller, Douglas, 2007. Does head start improve children's life chances? Evidence from a regression discontinuity design. Q. J. Econ. 122 (1), 159-208.

Mainali, Ram, Jafarey, Saqib, Montes-Rojas, Gabriel, 2017. Earnings and caste: an evaluation of caste wage differentials in the Nepalese labour market. J. Dev. Stud. 53 (3), 396-421.
Maitra, Pushkar, Mani, Subha, 2017. Learning and earning: evidence from a randomized evaluation in India. Lab. Econ. 45, 116-130.

Majlesi, Kaveh, 2016. Labor market opportunities and women's decision making power within households. J. Dev. Econ. 119, 34-47.

Malamud, Ofer, Pop-Eleches, Cristian, 2010. General education versus vocational training: evidence from an economy in transition. Rev. Econ. Stat. 92 (1), 43-60.

Martinez, Sebastian, June 2011. Impacts of the Dominican Republic Youth Employment Program: Hard Skills or Soft Skills: Intermediate Impact Results. Powerpoint delivered at the World Bank-SIEF Working Camp in Washington, DC on April 19th, 2010.

McCrary, Justin, 2008. Manipulation of the running variable in the regression discontinuity design: a density test. J. Econom. 142 (2), 698-714.

McKenzie, David, 2017. How effective are active labor market policies in developing countries? a critical review of recent evidence. World Bank Res. Obs. 32 (2), $127-154$.

Meyer, Bruce D., 1995. Natural and quasi-experiments in economics. J. Bus. Econ. Stat. 13 (2), 151-161.

Miller, Grant, Pinto, Diana, Vera-Hernandez, Marcos, 2013. Risk protection, service use, and health outcomes under Colombia's health insurance program for the poor. Am. Econ. J. Appl. Econ. 5 (4), 61-91.

Nayar, Reema, 2011. More and Better Jobs in South Asia. World Bank Publications.

Nikolov, Plamen, Jimi, Nusrat, 2018. What factors drive individual misperceptions of the returns to schooling in Tanzania? Some lessons for education policy. Applied Econ. 50 (44), 4705-4723.

Reis, Mauricio, 2015. Vocational training and labor market outcomes in Brazil. B E J. Econ. Anal. Pol. 15 (1), 377-405.

Smith, Jeffrey, Todd, Petra E., 2005. Does matching overcome LaLonde's critique of nonexperimental estimators. J. Econom. 125, 305-353.

Suwal, Rudra, Pant, Bishnu, 2009. Measuring informal sector economic activities in Nepal. In: Paper Prepared for the Special IARIW-SAIM Conference on Measuring the Informal Economy in Developing Countries, Kathmandu, Nepal.

The World Bank, 2011. World Development Report 2012: Gender Equality and Development. The World Bank.

The World Bank, 2013. World Development Report 2013: Jobs. The World Bank.

UNESCO, 2007. The State of Education in Latin America and the Caribbean: Guaranteeing Quality Education for All. OREALC/UNESCO Santiago.

United Nations, 2012. World Population Monitoring: Adolescents and Youth. United Nations.

USAID, 2015. Key Soft Skills that Foster Youth Workforce Success: toward a Consensus across Fields. Workforce Connections. USAID. June 19, 2018. https://www.usaid. gov/sites/default/files/documents/1865/KeySoftSkills.pdf. 